Universidade de Brasília - UnB Instituto de Artes

Departamento de Desenho Industrial Curso de Desenho Industrial

VIS 157597 - Projeto de Diplomação em Programação Visual

PROJETO GRÁFICO DE UM “KIT” PARA CAMPANHA DE CONSCIENTIZAÇÃO SOBRE SAÚDE

\author{
Por \\ PAULA PEREIRA SCHERRE \\ TEREZA CRISTINA PIRES DA SILVA
}

Brasília, julho de 2004 
Universidade de Brasília - UnB

Instituto de Artes

Departamento de Desenho Industrial

Curso de Desenho Industrial

VIS 157597 - Projeto de Diplomação em Programação Visual

\section{PROJETO GRÁFICO DE UM “KIT” PARA CAMPANHA DE CONSCIENTIZAÇÃO SOBRE SAÚDE}

Trabalho de diplomação elaborado sob a orientação do Professor Felipe Lopes, do Instituto de Artes, curso de Desenho Industrial pelas alunas Paula Pereira Scherre, matrícula 99/27107 e Tereza Cristina Pires da Silva, matrícula 99/27182, habilitação em Programação Visual $1^{0}$ semestre de 2004 


\section{Agradecimentos}

Agradecemos ao Hospital de Apoio de Brasília e seus profissionais de saúde por abrirem as portas e estarem sempre abertos a novas idéias e oportunidades de crescimento. Agradecemos ao professor Felipe Cruz, nosso orientador, que realmente nos orientou em todos os momentos e ouviu nossas dúvidas e angústias com paciência. Agradecemos ao professor Áderson, de psicologia da infância, pelo acompanhamento, incentivo e aulas de qualidade. Agradecemos à Dra. Sílvia, psicóloga responsável do HAB, pela disposição e ânimo nas conversas no hospital e abertura para tudo o que levamos. Agradecemos à Dra. Raquel, médica do $H A B$, pelo incentivo e pelas valiosas trocas de informações. Agradecemos ao Dennis Inokuchi pela amizade, paciência e prontidão em nos ajudar e pela ilustração de personagens tão carismáticos que representam a campanha com alegria! Agradecemos ao Mateus Fernandes pela criação da poesia que apresenta a campanha e a aceitação das nossas sugestões. Agradecemos à Dona Marta, mãe da Paula, pela correção detalhada da nossa monografia. Agradecemos aos amigos, Anne, James, Marilda, Pedro e Suzana pelas contribuições no decorrer do projeto. Agradecemos à Universidade de Brasília, ao Departamento de Desenho Industrial e a todos os professores que participaram da nossa formação e contribuíram com este projeto. Agradecemos às nossas famílias, amigos $e$ namorados por nos darem apoio, incentivo e compreenderem os momentos de angústia durante o projeto. Agradecemos aos nossos pais, os responsáveis por nossas vidas, pelo eterno incentivo em tudo o que acreditamos. Agradecemos a Deus por ter nos ajudado em nossas escolhas, e estar sempre presente!

\section{Paula Scherre e Tereza Pires}




\section{SUMÁRIO}

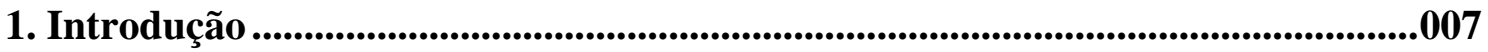

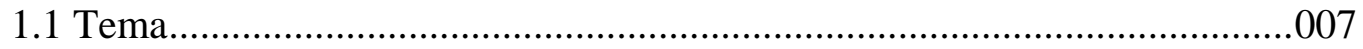

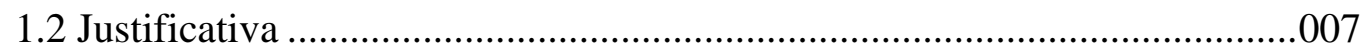

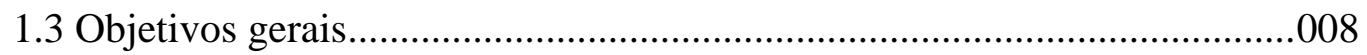

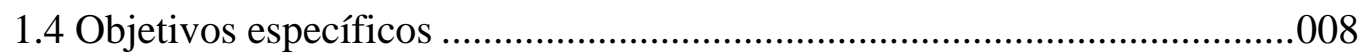

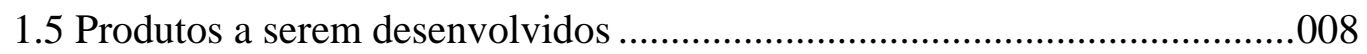

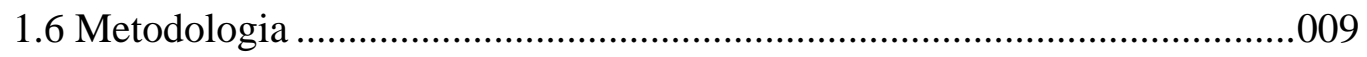

2. Campanha e escolha do nome .............................................................................11

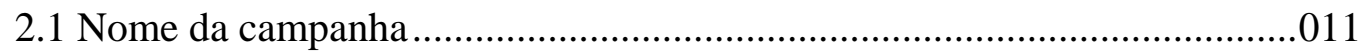

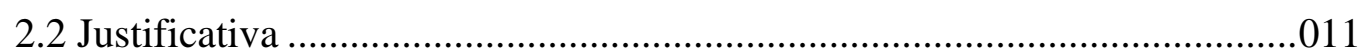

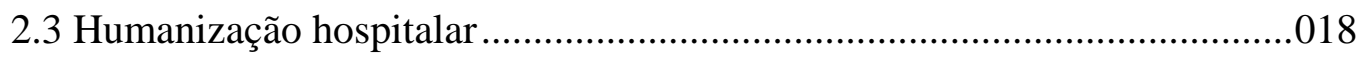

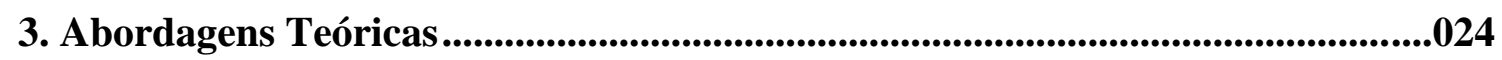

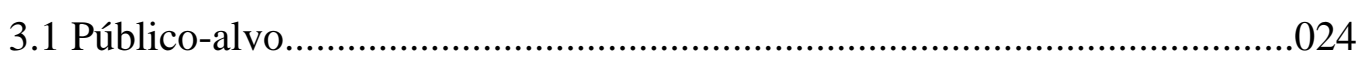

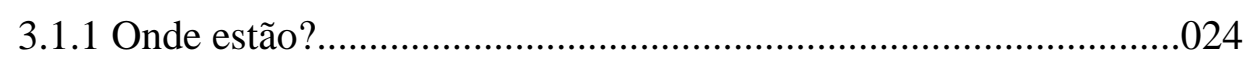

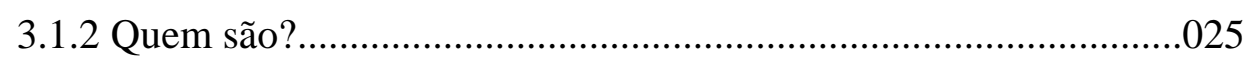

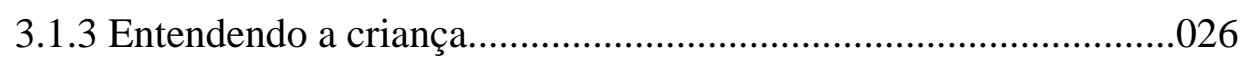

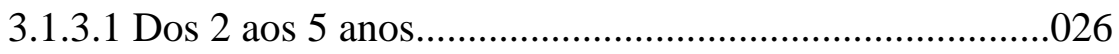

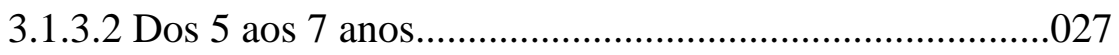

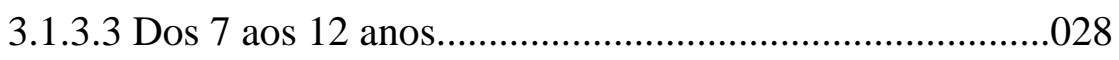

3.1.3.4 Os efeitos da pobreza no desenvolvimento.....................029

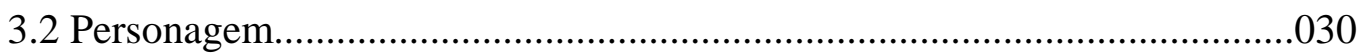

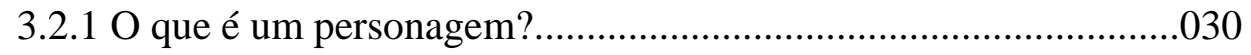

3.2.2 Personagem x Imaginário da criança.........................................032

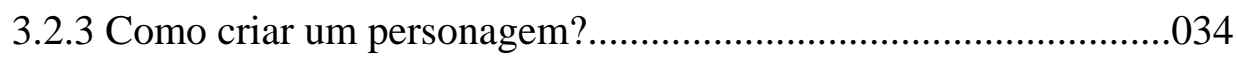

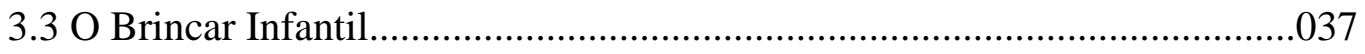

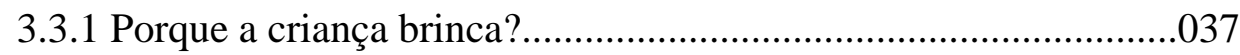

3.3.2 Jogo na educação e no hospital...................................................038

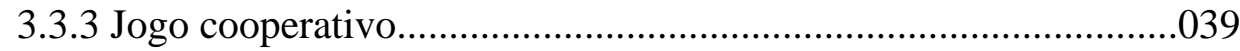

3.3.4 Alguns requisitos para o desenvolvimento do jogo.......................040

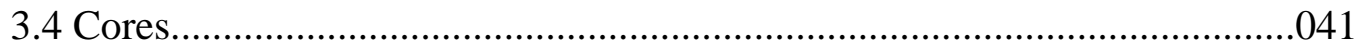

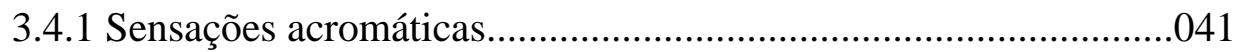


3.4.2 Sensações cromáticas......................................................................043

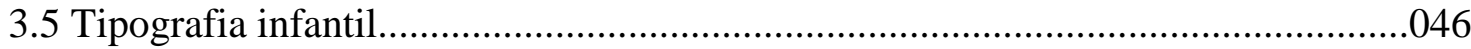

4. Desenvolvimento do projeto .......................................................................................048

4.1 Informações contempladas nos painéis de apresentação.............................048

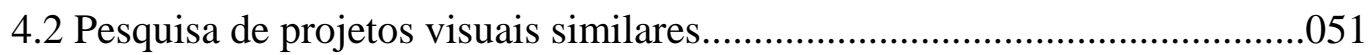

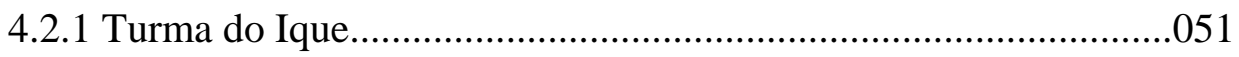

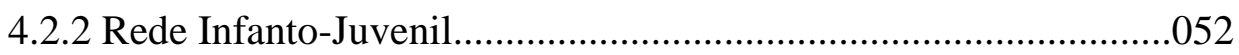

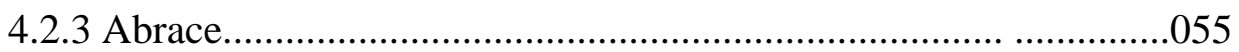

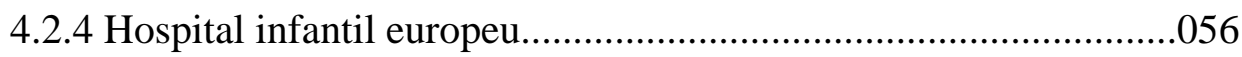

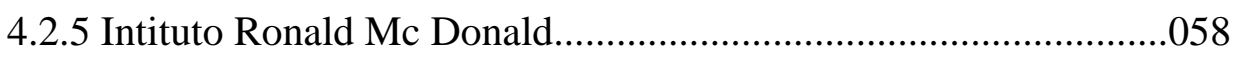

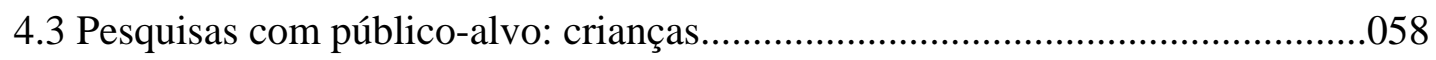

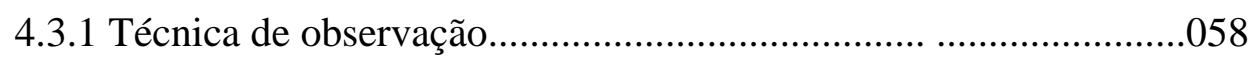

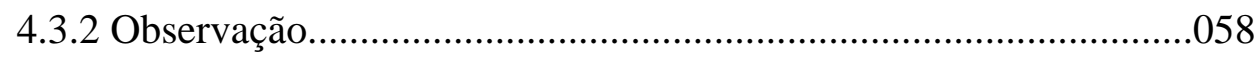

4.3.2.1 Dados da observação.....................................................059

4.3.2.2 Conclusão da observação..............................................061

4.3.3 Técnica de entrevista................................................................062

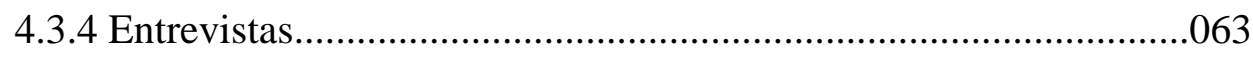

4.3.4.1 Entrevista com estagiária do HAB: Catarina...................063

4.3.4.2 Entrevista com mestranda: Rejane...............................066

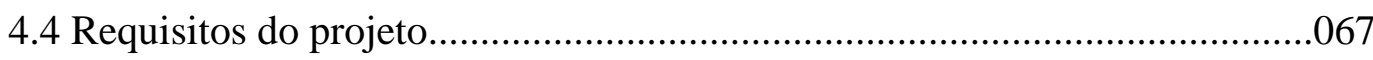

4.5 Geração de alternativas e desenvolvimento da solução................................068

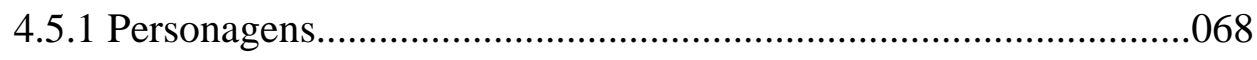

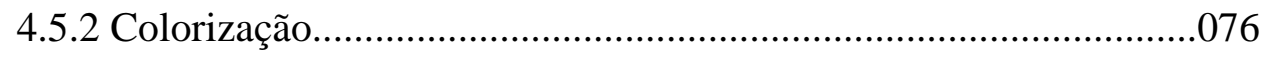

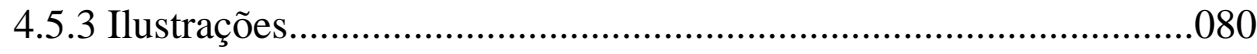

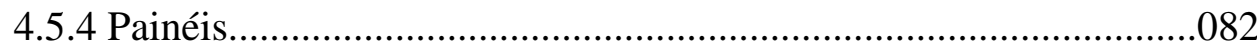

4.5.4.1 Objetivos e restrições.....................................................082

4.5.4.2 Resumidos e detalhados..................................................083

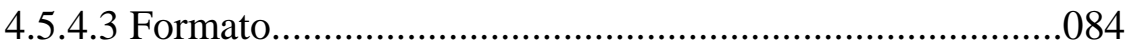

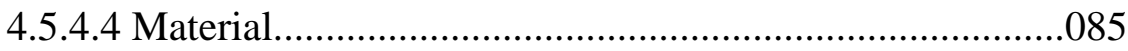

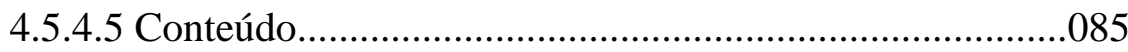

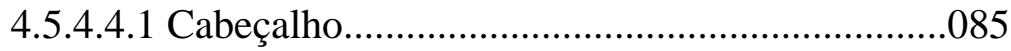

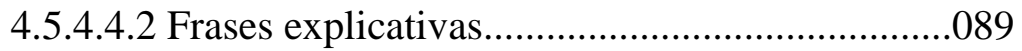

4.5.4.4.3 Personagens no painel.......................................091

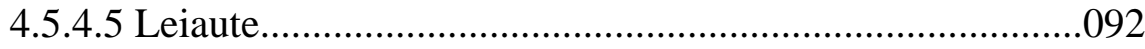




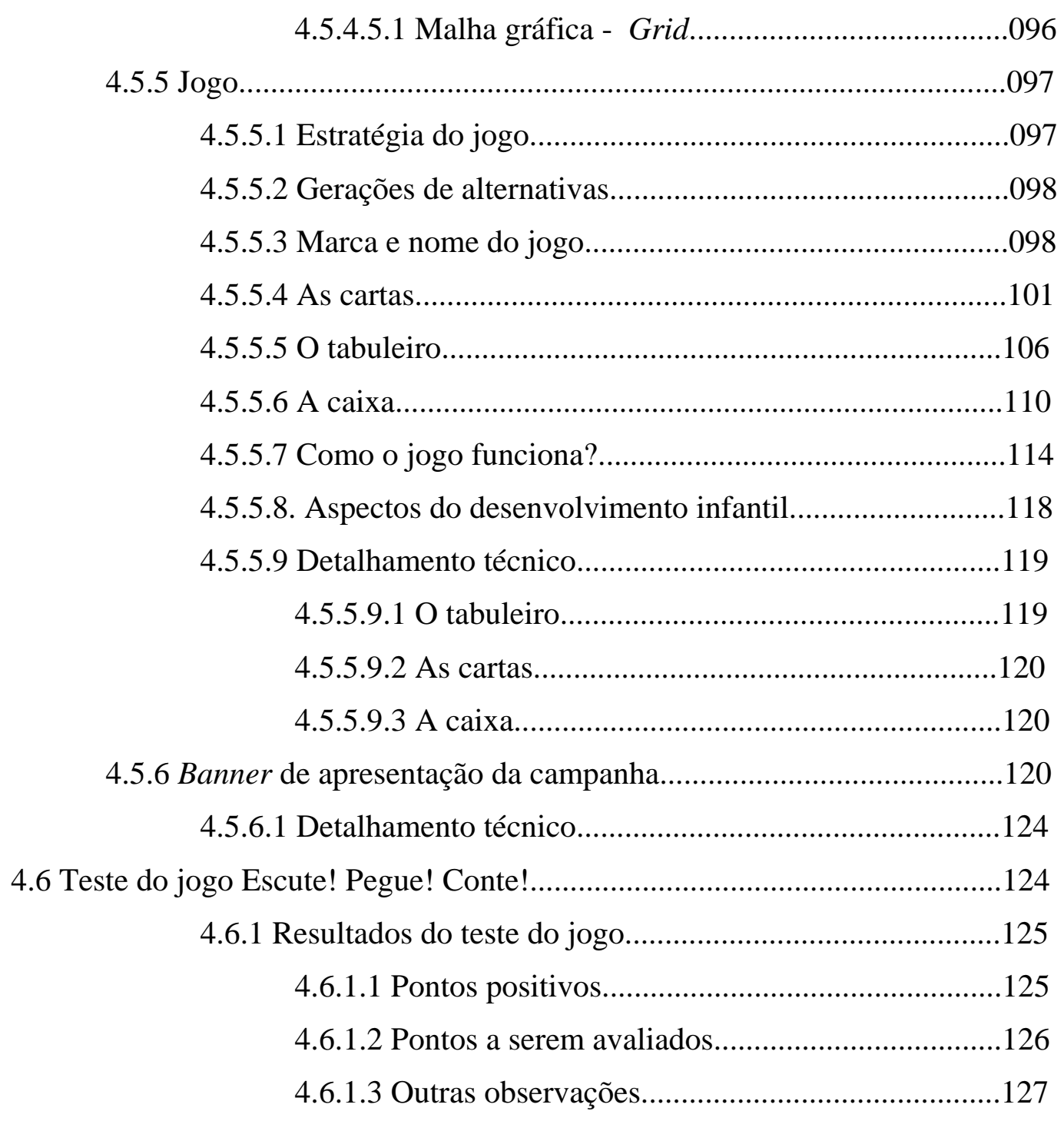

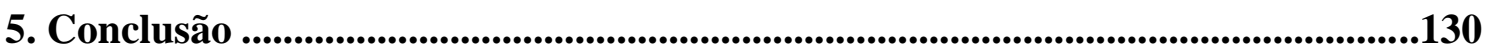

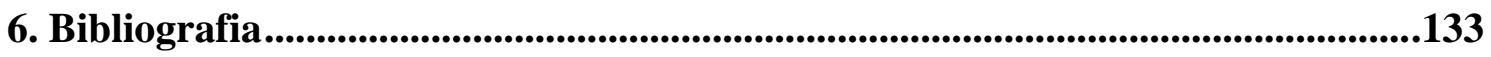




\section{INTRODUÇÃO}

\subsection{Tema do projeto}

Projeto Gráfico de um “kit” para campanha de conscientização sobre saúde.

\subsection{Justificativa}

O projeto, desde o início, procura colaborar com a sociedade e a realidade e tem como principal iniciativa o tema “crianças”. Encontra-se no Hospital de Apoio a necessidade latente de realizar este projeto, unindo-se o tema idealizado e as crianças, com a responsabilidade de um trabalho real e de grande cunho social.

O projeto visual do "kit” surgiu da necessidade dos profissionais de saúde (médicos, psicólogos, nutricionistas, dentistas e assistentes sociais) do Hospital de Apoio de passar informações básicas e importantes aos pacientes (crianças) e acompanhantes (pais). Porém, como hoje é realizado, somente pelas explanações orais e verbais, as informações sobre os hábitos ligados à higiene, alimentação, cuidados odontológicos, limpeza e sobre a doença falciforme e o câncer, não são plenamente compreendidas e assimiladas. O “kit” torna-se ainda mais necessário devido ao baixo nível sócio-econômico e cultural dos pais e à faixa etária em que as crianças se encontram, razões que dificultam ainda mais a compreensão e assimilação das informações. 


\subsection{Objetivos gerais}

O Projeto tem dois objetivos principais:

- Desenvolver um projeto gráfico para material de apoio às explanações, hoje realizadas apenas oral e verbalmente, tornando-as mais compreensíveis pelos envolvidos com o assunto saúde.

- Desenvolver um jogo para crianças de 6 a 12 anos para reforçar conhecimentos sobre saúde.

\subsection{Objetivos específicos}

- Instruir e conscientizar os envolvidos (crianças, pais, médicos, nutricionistas, psicólogos, dentistas, assistentes sociais) quanto aos hábitos ligados à higiene, à alimentação, aos cuidados odontológicos, à limpeza, à doença falciforme e ao câncer;

- Estimular o maior envolvimento dos pais e crianças nos grupos informativos ${ }^{1}$ e esclarecer suas dúvidas;

- Estimular a compreensão, de maneira mais lúdica para a criança, das informações necessárias por meio de cores, formas e personagens;

- Promover maior identificação da criança com personagens criados, gerando maior conforto e aceitação da doença, tratamento, procedimentos e novos hábitos.

\subsection{Produtos a serem desenvolvidos}

- Identidade visual do "kit” da campanha, formado por painéis e um jogo;

- Personagens e ilustrações;

- Identidade visual dos personagens e das ilustrações;

\footnotetext{
${ }^{1}$ Grupos informativos: reuniões informais por meio das quais psicólogos conversam com os pais e crianças sobre tudo o que se relaciona aos hábitos ligados à higiene, à alimentação, aos cuidados odontológicos, à limpeza, à doença falciforme e ao câncer aproveitando o tempo de espera das consultas.
} 
- Painéis ilustrativos para auxílio em explanações;

- Jogo.

A identidade visual do "kit” significa dar a mesma linguagem visual, através de cores, formas, tipografia, diagramação, estilo dos personagens aos painéis e ao jogo, que serão desenvolvidos como produtos principais deste projeto em questão.

Os personagens são “criaturas” que tornarão mais fácil, para a criança, a assimilação e a aceitação dos conhecimentos transmitidos pelos profissionais de saúde. Os personagens serão as figuras responsáveis por exemplificar todas as ações colocadas nas explanações e por tornar essas situações mais próximas das condições e da realidade da criança. Como a criança aprende brincando e seu imaginário é sua projeção na realidade, a estimulação positiva do imaginário da criança refletirá em suas atitudes no seu dia-a-dia.

Os Painéis serão pranchas em formato A3, plastificadas, que irão conter as informações, ilustrações e personagens que auxiliarão efetivamente as explanações.

O Jogo será uma atividade voltada para crianças de 6 a 12 anos, que complementará as explanações reforçando os conceitos e informações transmitidos nos painéis e nas explanações. Pretende-se que o jogo seja dinâmico, possibilitando a interação entre crianças, pais e profissionais de saúde.

\subsection{Metodologia}

Como metodologia para o desenvolvimento deste projeto, seguiu-se a seguinte ordem didática de etapas:

- Delimitação do tema e definição do problema

- Definição de conteúdo e da situação problema

- Pesquisa bibliográfica

- Definição dos requisitos do projeto 
- Geração de alternativas

Essa ordem é didática, pois, durante todo o desenvolvimento do projeto, todas as etapas vão acontecendo em conjunto e o importante da divisão é que em cada uma delas dar-se-á ênfase a um aspecto do projeto.

Também opta-se por uma metodologia que possibilite a passagem por essas etapas diversas vezes. Com a mesma ênfase em cada etapa, mas retornando-se a elas, surgem oportunidades de perceber cada etapa de maneira diferente, acrescentar, mudar ou retirar conceitos ou requisitos dependendo do desenvolvimento dos produtos.

Com exceção da delimitação do tema e da definição do problema que foram explicitados no início desta introdução, todas as etapas da metodologia, até agora realizadas, serão descritas e detalhadas no decorrer deste relatório. 


\section{CAMPANHA DE CONSCIENTIZAÇÃO SOBRE SAÚDE}

\subsection{Nome da campanha}

Amigos para Sempre: a Saúde, o Cuidado e Você!

\subsection{Justificativa}

A escolha de um nome para essa campanha de conscientização deu-se pelo fato de compreendermos que a partir da definição de um nome será possível definir com maior facilidade uma mesma linguagem para o projeto gráfico de todo o "kit”, já que todos os seus componentes estarão envolvidos por um mesmo conceito.

O nome “Amigos para Sempre: a Saúde, o Cuidado e Você!” faz parte de uma idéia que visa chamar a atenção para conceitos muito importantes para o ambiente do hospital: a saúde e o cuidado. São conceitos que devem sempre estar presentes na vida de qualquer pessoa, principalmente das crianças e pais que freqüentam o hospital. A saúde é o que se busca a todo o momento, por isso as crianças estão em tratamento e o cuidado é o que os pais e crianças devem ter durante toda sua vida. Busca-se tudo isso para evitarem maiores complicações e para alcançarem e manterem a saúde.

Para reforçar esses conceitos e agregar empatia entre as crianças e os respectivos conceitos, transformaram-se as palavras “saúde” e “cuidado” nos nomes dos personagens. Assim, a todo o momento, essas duas palavras agregam mais de um significado, o significado de saúde e da personagem “a Saúde” e o significado de cuidado e do personagem “o Cuidado”, respectivamente. Essa ligação tão próxima, dos personagens com esses conceitos, deixa claro aos envolvidos quais informações estão sendo valorizadas e reforçadas com a campanha. 
O discurso direto do nome evidencia o convite a participar da campanha. O nome já reconhece a participação de "Você” na campanha. Já mostra que "Você” está envolvido com a saúde, “a Saúde”, o cuidado e "o Cuidado”. Além de chamar a atenção, pelos significados agregados, ele também mantém essa atenção convidando para serem “amigos para sempre”.

Para esclarecer ainda mais os dois significados agregados à saúde e ao cuidado e reforçar a ligação dos conceitos da campanha com os envolvidos, além dos personagens haverá um texto - uma poesia -, que mostrará, por escrito, essa brincadeira e relação entre os conceitos e os personagens. Será um texto que acompanhará a campanha, ajudando na apresentação dela e tornando-a mais lúdica. 


\section{Poesia - primeira versão}

\section{Amor necessário}

Mateus Fernandes - 04/05/2004

Decidiram juntos andar

a saúde e o cuidado

Assim tudo começou a melhorar

pois se precisavam lado a lado

O problema insistia em aparecer

toda vez que alguém se descuidava

E a saúde, sem saber por que,

logo se separava...

- O cuidado fugiu novamente, o que fazer?

E assim tudo novamente começava

Nasceram juntos, é verdade

Mas nem sempre juntos andavam...

A saúde, mocinha direita e bondosa

O cuidado, moleque esperto e de pouca idade

Nem sempre se agüentavam...

A saúde nascera primeiro

sempre coberta de presente

Pois quando ela ficava contente

tudo ia bem o dia inteiro

Mas era só ficar chateada pra querer fugir de casa

Ô menina danada

pra brincar de pique-esconde

e ficar fugida na noite varada!

Já o cuidado, que veio depois,

existia antes mesmo de nascer

É assim mesmo, vai entender...

Os outros faziam ele aparecer

na hora que fosse preciso

Pois a vida sem cuidado

é pior que vida sem juízo...

Antes do cuidado aparecer

a coisa era mais difícil:

Quem não podia ter cuidado por si

era cuidado com algum artifício

Alguém olhava, vigiava, examinava...

Mas era sempre cuidado por alguém

O que não podia acontecer era viver sem o cuidado de ninguém...

Ah!

E quando o cuidado nasceu

também foi festa e alegria

Pois a saúde acabara de ganhar

o companheiro do dia a dia

No começo era complicado

pois a saúde não conhecia o cuidado 
e achava que dele não precisava

Mas foi só ficar sozinha a primeira vez

que acabou a timidez

Viraram bons amigos de vez!

e ninguém mais ficou chateado

A saúde foi crescendo e ficando forte

com a ajuda do cuidado

Mas eram tão amigos

que era só ele sumir um bocado

que a saúde já sentia os avisos:

- Pra onde foi esse moleque desavisado?

- Cadê o juízo de vocês, foi roubado?

- O que aconteceu que o cuidado anda tão

calado?

Porque a coisa funciona assim:

Se o cuidado está abalado

ou se ele some de repente

a saúde sabe que ficará mal

e não fará bem pra gente...

Pois é só ela ficar distraída

pra que a gente sofra todo o tipo de recaída

Fique de cama, doente e triste

querendo achar o cuidado

mas tendo de ficar deitado

sem nenhuma outra saída...
Portanto, o melhor a fazer

é sempre se precaver

Ter atenção com o cuidado

e carinho com a saúde

nunca faz mal em demasiado

E, então, pode escrever:

- Tá tudo arrumado!

A gente pode viver bem e contente

E mesmo que a saúde ande fraca

se o cuidado está ao lado

então pode ficar sossegado

Ela logo volta a se animar

e tudo ao seu redor também fica animado!

Essa é a festa que rola

quando andam, lado a lado,

a saúde e o cuidado. 
A primeira versão da poesia, “Amor necessário”, conseguiu passar a idéia da brincadeira entre os dois conceitos. É dessa forma, contando uma estória com os personagens Saúde e Cuidado, que se pode explicar de maneira lúdica os conceitos de saúde e cuidado. Porém, algumas observações são importantes para que o objetivo da poesia consiga ser atingido. A poesia “Amor necessário” é extensa e, para uma apresentação da campanha, deve ser menor. Há o uso de algumas palavras mais complexas possivelmente mais difíceis de uma criança entender, quanto mais nova for ela. Outro fator importante é que nessa poesia não há o "você” da campanha “Amigos para sempre: a Saúde, o Cuidado e Você!”. O “você” é importante, pois a campanha existe para “você”. É o “você” que a campanha precisa conquistar. Assim, com a intenção de apresentar uma poesia que chegasse aos envolvidos com a campanha, principalmente às crianças, uma segunda e última versão foi criada. 
Poesia - segunda versão

Amigos para sempre: a Saúde, o Cuidado

e Você!

Mateus Fernandes - 04/05/2004

Decidiram juntos andar

a saúde e o cuidado

Assim tudo começou a melhorar

E cada um dava seu recado

Mas e você, onde entra nessa estória?

Será que está do lado errado?

Acho que não...

Se não me falha a memória

A saúde lhe quer como amiga

E o cuidado como parceiro

Para que, todos juntos,

Divirtam-se o dia inteiro!

Precisam ficar juntos, é verdade

Mas nem sempre juntos andavam...

A saúde, mocinha direita e bondosa

O cuidado, moleque esperto e de pouca idade
Nem sempre se agüentavam...

A vida com saúde,

É vivida sempre feliz!

Já a vida sem cuidado

É ver a vida por um triz!

Não vale a pena se arriscar

Você tem um grande papel nessa estória

A saúde com o cuidado você deve juntar

E ficar com toda a glória!

Os dois se dão bem sozinhos

Mas devem sempre ser unidos por alguém

O que não podia acontecer

era ficarem sem ninguém

E é aí que entra você!

No começo era complicado

pois a saúde não conhecia o cuidado

e achava que dele não precisava

Mas foi só ficar sozinha a primeira vez

que acabou a timidez

Viraram bons amigos de vez!

e ninguém mais ficou preocupado 
Você não deve querer

Ficar sozinho e triste na vida

Pois mesmo tendo de ficar deitado

deve ter carinho com a saúde querida e

atenção em dobro com o cuidado

E, então, pode escrever:

- Tá tudo arrumado!

A gente pode viver bem e contente

E mesmo que a saúde ande fraca

se o cuidado está ao lado

então pode ficar sossegado

Essa é a amizade mais bonita

quando andam, lado a lado,

você, a saúde e o cuidado! 


\subsection{Humanização hospitalar}

O Hospital de Apoio de Brasília faz parte de uma política nacional do Ministério da Saúde para a humanização do sistema hospitalar público brasileiro: o HumanizaSUS Política Nacional de Humanização. De acordo com o site do Ministério da Saúde, o HumanizaSUS ${ }^{2}$ é:

\footnotetext{
"É a proposta de uma nova relação entre usuário, os profissionais que o atendem e à comunidade.

Todos juntos trabalhando para que o SUS seja mais acolhedor, mais ágil, com locais mais confortáveis. Que atenda bem a toda comunidade.

Um SUS que reconhece e respeita a diversidade do povo brasileiro e a todos oferece o mesmo tratamento, sem distinção de raça, cor, origem ou orientação sexual.

Queremos um SUS mais humano. Construído com a participação de todos: trabalhadores, gestores e usuários. Comprometido com a qualidade dos seus serviços e com a saúde integral para todos. Isso é o HumanizaSUS.”
}

Para entender com mais detalhes como essa política funcionará, é necessário

compreender outros aspectos como:

O que se entende por humanização ${ }^{3}$ :

- Valorização dos diferentes sujeitos implicados no processo de produção de saúde: usuários, trabalhadores e gestores;

- Fomento da autonomia e do protagonismo desses sujeitos;

- Aumento do grau de co-responsabilidade na produção de saúde e de sujeitos;

- Estabelecimento de vínculos solidários e de participação coletiva no processo de gestão;

- Identificação das necessidades sociais de saúde;

- Mudança nos modelos de atenção e gestão dos processos de trabalho tendo como foco as necessidades dos cidadãos e a produção de saúde;

- Compromisso com a ambiência, melhoria das condições de trabalho e de atendimento.

O que se pretende com essa política nacional de humanização ${ }^{4}$ :

- Reduzir as filas e o tempo de espera com ampliação do acesso e atendimento acolhedor e resolutivo baseados em critérios de risco;

- Todo usuário do SUS saberá quem são os profissionais que cuidam de sua saúde e os serviços de saúde se responsabilizarão por sua referência territorial;

- As unidades de saúde garantirão as informações ao usuário, o acompanhamento de pessoas de sua rede social (de livre escolha) e os direitos do código dos usuários do SUS;

- As unidades de saúde garantirão gestão participativa aos seus trabalhadores e usuários assim como educação permanente aos trabalhadores.

\footnotetext{
${ }^{2}$ http://portal.saude.gov.br/saude/area.cfm?id_area=389

${ }^{3}$ http://portal.saude.gov.br/saude/area.cfm?id_area=390

${ }^{4}$ http://portal.saude.gov.br/saude/area.cfm?id_area=391
} 
Quais são os objetivos (MINISTÉRIO DA SAÚDE, 2002, p.14):

- Difundir uma nova cultura de humanização na rede hospitalar pública brasileira;

- Melhorar a qualidade e a eficácia da atenção dispensada aos usuários dos hospitais públicos no Brasil;

- Capacitar os profissionais dos hospitais para um novo conceito de assistência à saúde que valorize a vida humana e a cidadania;

- Conceber e implantar novas iniciativas de humanização dos hospitais que venham a beneficiar os usuários e os profissionais de saúde;

- Fortalecer e articular todas as iniciativas de humanização já existentes na rede hospitalar pública;

- Estimular a realização de parcerias e intercâmbio de conhecimentos e experiências nesta área;

- Desenvolver um conjunto de indicadores de resultados e sistema de incentivos ao tratamento humanizado;

- Modernizar as relações de trabalho no âmbito dos hospitais públicos, tornando as instituições mais harmônicas e solidárias, de modo a recuperar a imagem pública dessas instituições junto à comunidade;

\section{O que é preciso fazer para atingir esses objetivos ${ }^{5}$ :}

- Ampliar o diálogo entre os profissionais, entre profissionais e população, entre profissionais e administração, promovendo a gestão participativa;

- Implantar, estimular e fortalecer Grupos de Trabalho de Humanização com plano de trabalho definido;

- Estimular práticas resolutivas, racionalizar e adequar o uso de medicamentos, eliminando ações intervencionistas desnecessárias;

- Reforçar o conceito de clínica ampliada: compromisso com o sujeito e seu coletivo, estímulo a diferentes práticas terapêuticas e co-responsabilidade de gestores, trabalhadores e usuários no processo de produção de saúde;

- Sensibilizar as equipes de saúde ao problema da violência intrafamiliar (criança, mulher e idoso) e à questão dos preconceitos (sexual, racial, religioso e outros) na hora da recepção e dos encaminhamentos;

- Adequar os serviços ao ambiente e à cultura local, respeitando a privacidade e promovendo a ambiência acolhedora e confortável;

- Viabilizar participação dos trabalhadores nas unidades de saúde através de colegiados gestores;

- Implementar sistema de comunicação e informação que promova o autodesenvolvimento e amplie o compromisso social dos trabalhadores de saúde;

- Promover ações de incentivo e valorização da jornada integral ao SUS, do trabalho em equipe e da participação em processos de educação permanente que qualifiquem sua ação e sua inserção na rede SUS.

Além de todos os aspectos apresentados anteriormente, é importante saber quais são as definições/orientações para se conseguir alcançar os objetivos e propostas traçados para esta política. A seguir serão relacionadas somente as definições/orientações que interessam para esta monografia (MINISTÉRIO DA SAÚDE, 2002, p. 16-17):

\footnotetext{
${ }^{5}$ http://portal.saude.gov.br/saude/area.cfm?id_area=391
} 
- Propiciar o financiamento de projetos que melhorem a ambiência dos serviços: salas de conversa, espaços de conforto, mobília adequada, comunicação visual, etc 6 .

- Os serviços devem ser confortáveis, respeitar a privacidade e promover ambiência acolhedora $^{7}$.

- Os serviços devem promover a identificação da equipe, acolher a rede social dos usuários e garantir toda informação necessária ${ }^{8}$.

O Hospital de Apoio tem se empenhado em realizar todas essas mudanças e atualizações tanto em sua estrutura e como em seu ambiente para se adequar à proposta dessa política nacional de humanização. Nas fotos abaixo é possível ver detalhes da decoração voltada para uma ambiência para o público infantil.

Figura 2.1 - Fotos da decoração dos corredores do hospital

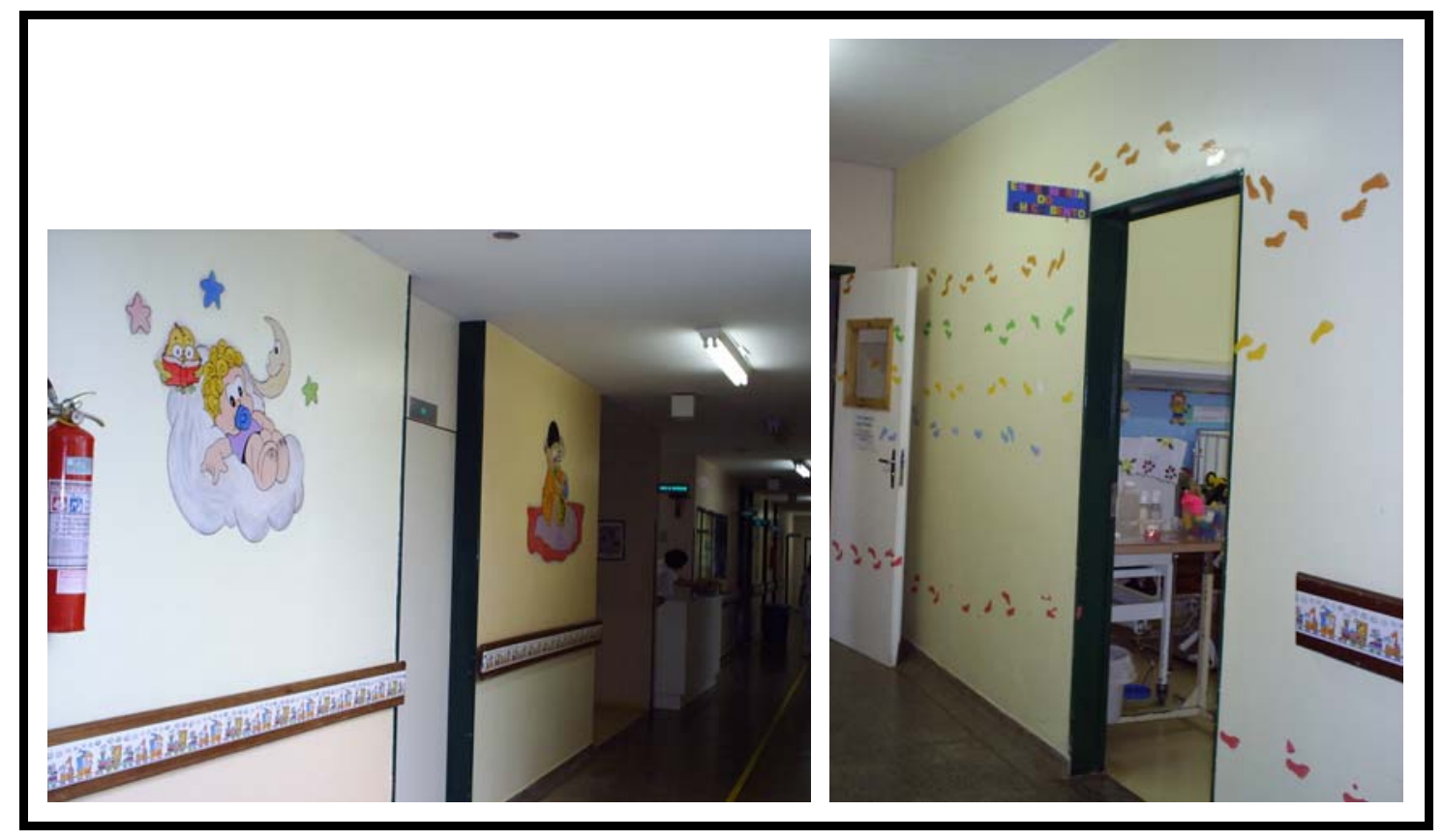

\footnotetext{
${ }^{6}$ MINISTÉRIO DA SAÚDE, 2002, p. 16

${ }^{7}$ Ibid., p. 17

${ }^{8}$ Ibid., p. 17
} 
Figura 2.2 - Fotos das enfermarias

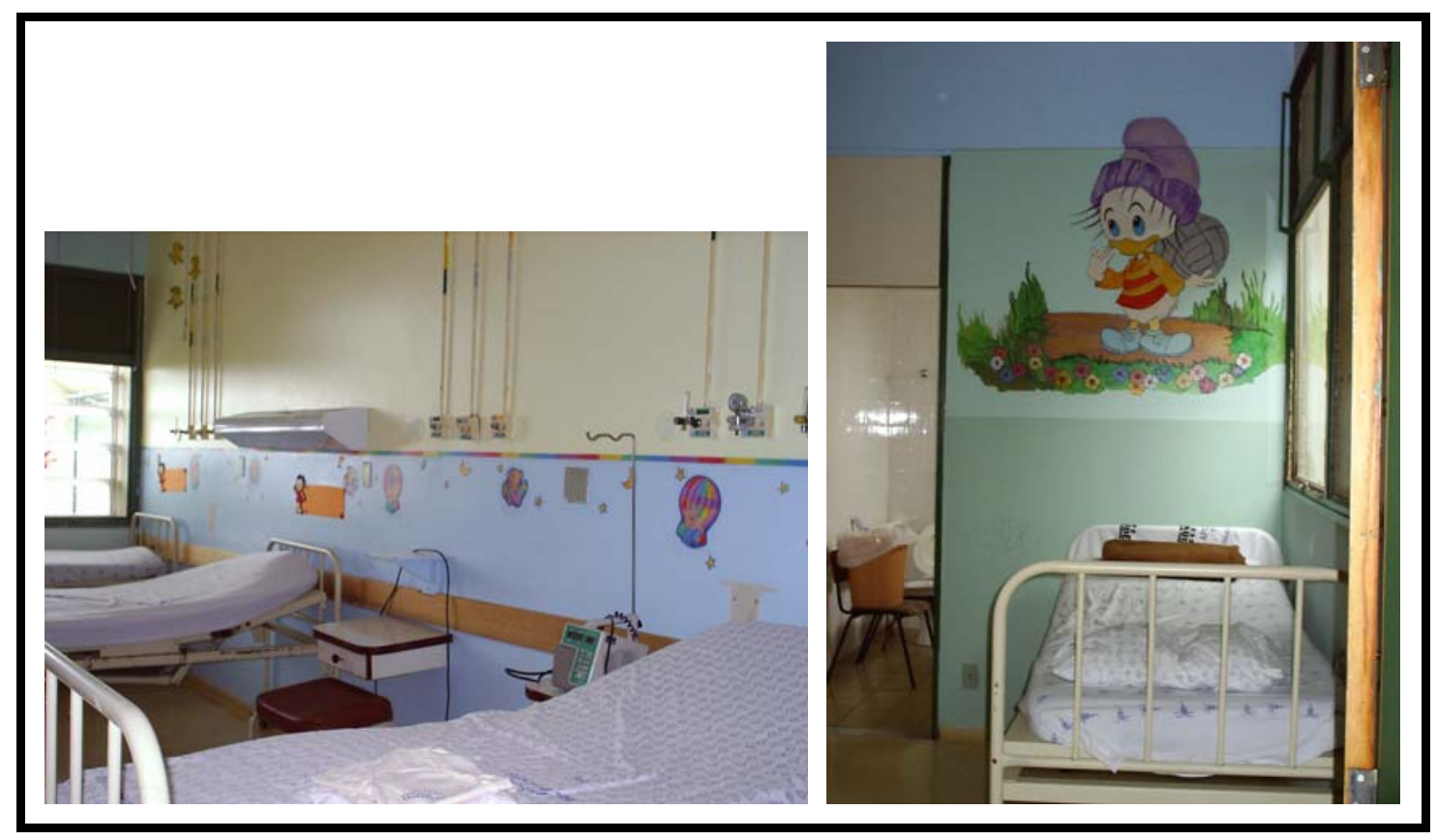

Figura 2.3 - Fotos de um consultório e da sala de quimioterapia

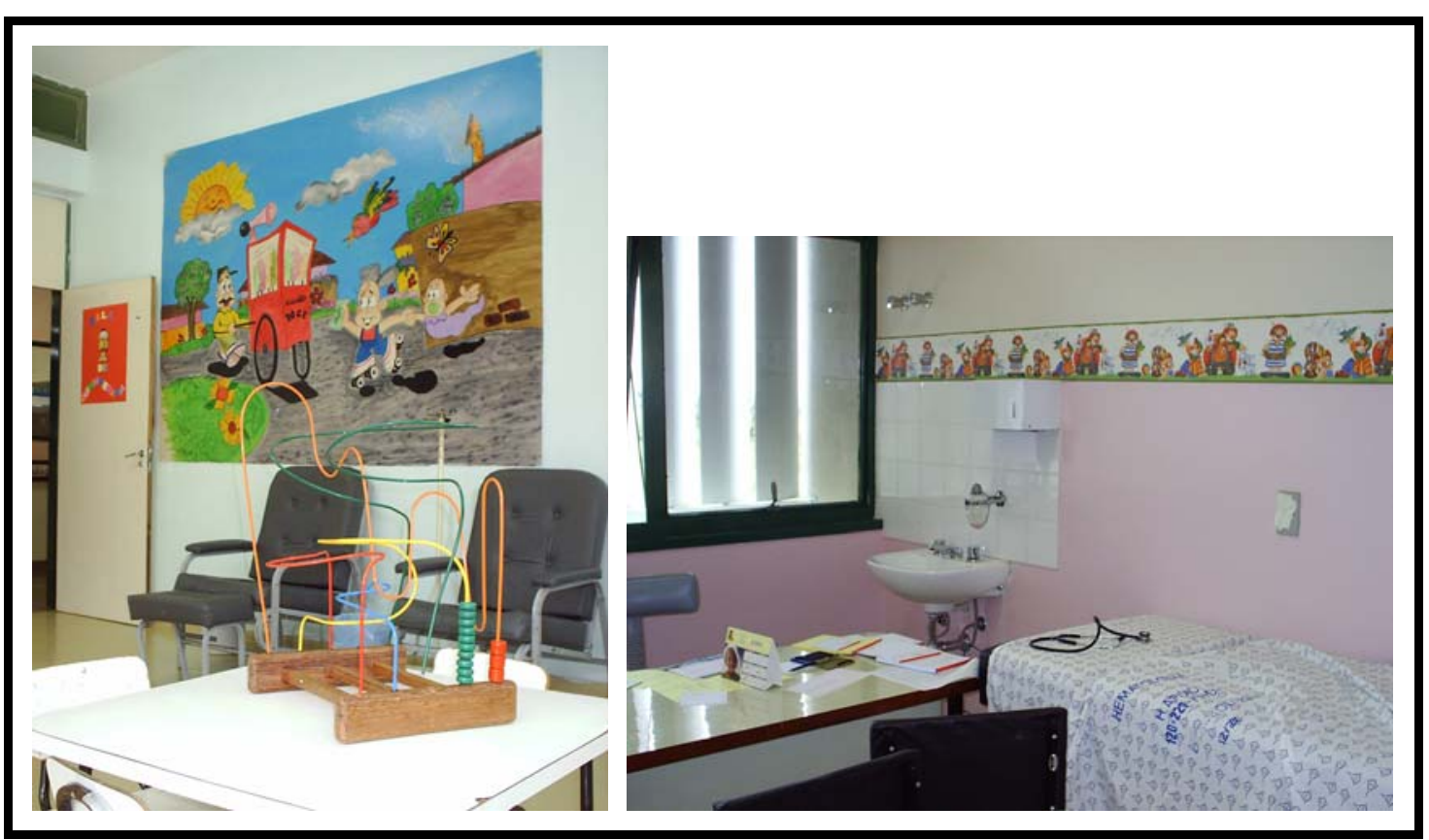

Durante algumas das visitas realizadas ao hospital foi possível ver a atuação dos “Pronto Sorriso”, voluntários vestidos de palhaços, responsáveis pela recreação dentro das enfermarias, principalmente para pacientes internados que não podem brincar na brinquedoteca. 
A brinquedoteca é um espaço voltado para a recreação das crianças enquanto esperam suas consultas. A recreação é feita em conjunto com outras crianças, com os pais e com outros profissionais de saúde, como estagiárias da psicologia, por exemplo.

Figura 1.4 - Fotos da brinquedoteca

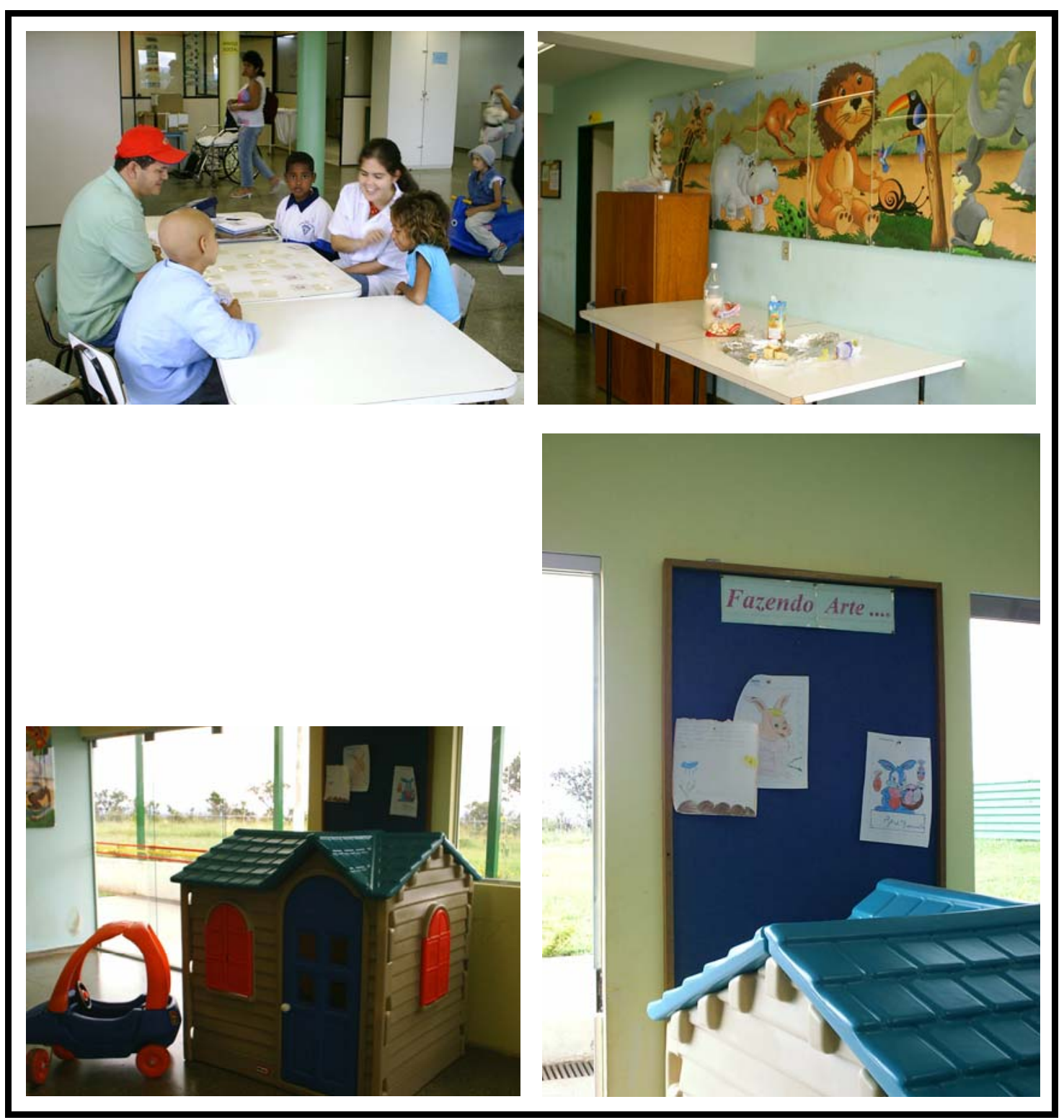

Durante os textos citados anteriormente retirados dos sites e manuais disponibilizados pelo Ministério da Saúde, pode-se perceber em vários momento a preocupação com “promover uma ambiência acolhedora e agradável”, “implementar sistema de comunicação e informação” e além disso, foi possível ver a preocupação com a comunicação visual quando se insere esta no "propiciar o financiamento de projetos que melhorem a ambiência dos 
serviços. Dessa forma, pode-se perceber as áreas e ocasiões nas quais o design se faz presente e necessário dentro de todo esse processo de humanização.

Sob essa filosofia de estar voltado completamente para a satisfação das necessidades dos usuários e os funcionários que os atendem, o projeto gráfico do "kit” - painéis e jogos para campanha de conscientização sobre saúde será criado e desenvolvido. 


\section{ABORDAGENS TEÓRICAS}

Nessa seção serão expostos os conteúdos e conceitos teóricos importantes que foram pesquisados durante a fase de pesquisa bibliográfica. A reunião de todas essas informações tem o objetivo de definir os conceitos e os requisitos de projeto e basear todas as escolhas feitas durante a fase posterior de geração de alternativas.

\subsection{Público-alvo}

\subsubsection{Onde estão?}

Figura 3.1 - Fotos da entrada principal do hospital e da entrada do Núcleo de OncoHematologia Pediátrica, onde se encontra a brinquedoteca

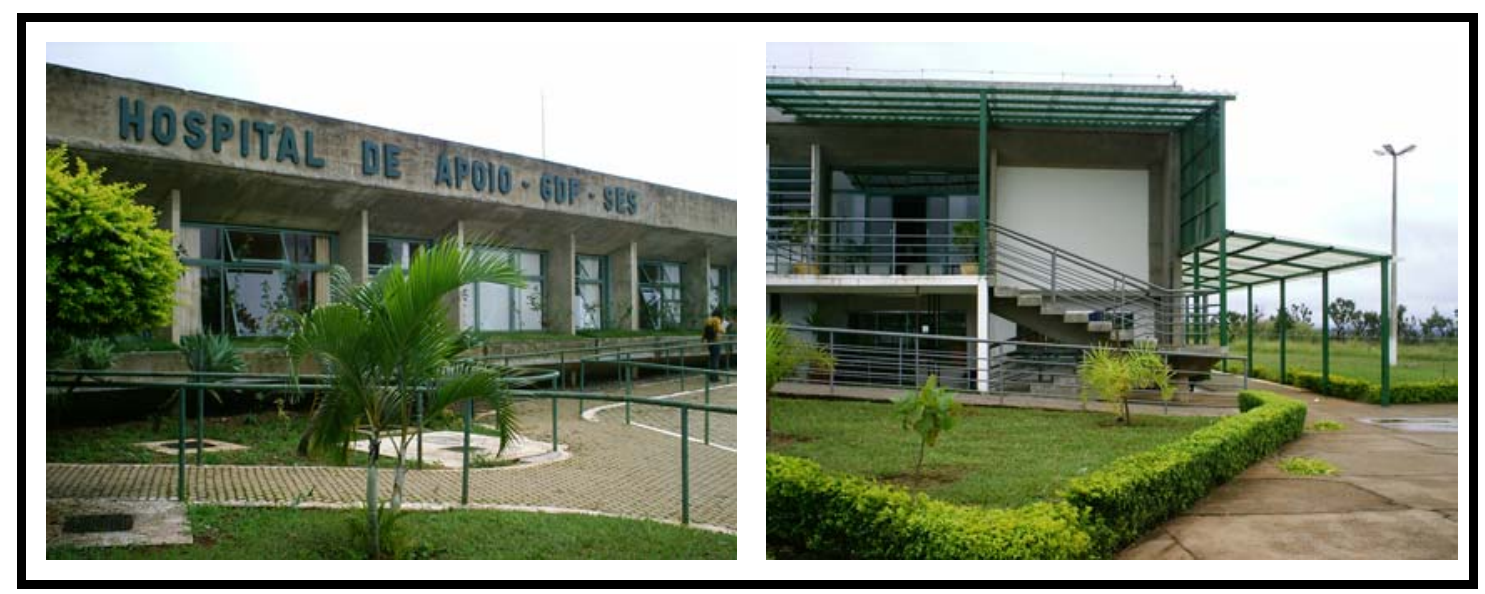

O público-alvo localiza-se no setor infantil do Hospital de Apoio, Núcleo de OncoHematologia Pediátrica - NOHP. São as crianças e acompanhantes - normalmente pais que freqüentam esse setor. Essa freqüência é consideravelmente grande, visto que se trata de um Hospital de Apoio. Algumas crianças ficam em tratamento durante um ou dois anos, freqüentando semanalmente o hospital para exames e consultas médicas, psicológicas e/ou odontológicas. As crianças também podem ficar internadas dependendo da sua situação. 
Esse setor do Hospital de Apoio está destinado apenas ao público infantil, sendo assim, o respectivo ambiente é todo voltado à criança. As enfermarias, os corredores e as salas de consultas são todas decoradas e coloridas, com animais, pegadas, elementos do imaginário da criança. Essa preocupação advém da intenção de fazer com que as crianças sintam-se o mais à vontade e felizes no hospital. Faz parte de todo um processo de humanização hospitalar encontrado em diversos momentos no Hospital de Apoio. Outro exemplo desse processo de humanização é a visita freqüente dos “Doutores da Alegria”, palhaços responsáveis por gerar sorrisos nas crianças que estão em tratamento.

Além de toda decoração, há uma sala de espera com diversos brinquedos, mesas para colorir ou jogar, como uma brinquedoteca. Nesta sala, as crianças e pais ficam esperando por consultas, exames. Enquanto isso as crianças brincam sozinhas ou em grupo com as psicólogas do hospital ou com voluntários. Há também café-da-manhã e lanche servidos todos os dias por voluntários.

\subsubsection{Quem são?}

O público-alvo deste projeto foi determinado a partir das conversas com os profissionais de saúde (médicos, psicólogos, nutricionistas, dentistas e assistentes sociais) do Hospital de Apoio. Pôde-se perceber, então, que o público-alvo são adultos (pais) e crianças de baixo nível sócio-econômico e cultural que freqüentam o hospital.

Os profissionais de saúde relataram a dificuldade em explicar certos conceitos por conta do baixo nível sócio-econômico. Relataram, também, a importância de mostrar imagens, ter brinquedos ou objetos que possam ser usados na explanação. Explicaram como o uso de metáforas ajuda a entender a doença, pois faz-se uma comparação do que acontece com a realidade de muitos. Por exemplo, comparar o que acontece com as células de alguém com câncer com uma plantação que está infestada de ervas daninhas, ou comparar com uma casa, 
onde as células são os tijolos e a importância de todos estarem bem, surte efeito positivo, pois muitos pais e crianças nem imaginam o que seja uma célula.

Como quem está em tratamento e é o foco da atenção do atendimento e do ambiente são as crianças, todas as pesquisas e esforços deste projeto estarão voltados para as características da criança e da infância, assim como todo esse setor do hospital explicado anteriormente. Porém, faz-se importante também que os pais compreendam as informações que serão transmitidas, principalmente porque "os pais são o modelo de comportamento que a criança imita” (Novello, 1987) e, sendo assim, quando há uma atitude responsável ou irresponsável, a criança também irá adotá-la. No entanto, se um conteúdo é exposto de maneira que uma criança entende, um adulto não terá dificuldades de compreendê-lo também.

\subsubsection{Entendendo a criança}

No caso do Hospital de Apoio, o grande público são de crianças que estão em tratamento e estas variam dos 2 a 12 anos, em média. Para que se possa produzir um material gráfico para crianças é importante compreender e ter noção de como se dá o desenvolvimento motor, a percepção visual, o desenvolvimento cognitivo, a aprendizagem. Todos esses aspectos são importantes porque influenciam significativamente a compreensão das informações que estão sendo transmitidas.

\subsubsection{Dos 2 aos 5 anos}

A criança torna-se mais coordenada, mais capaz de controlar o seu próprio corpo e desenvolve uma variedade de habilidades de automanutenção, tais como vestir-se e ir ao toalete sozinha. A criança pode mover-se com mais facilidade em seu ambiente e se diverte com isso. E, na medida em que o seu mundo amplia, a ligação afetiva e física com sua mãe torna-se mais fraca e seu envolvimento com os objetos e outras pessoas aumenta. 
As mudanças mais importantes durante esse períodos são as que dizem respeito às relações interpessoais. Ela busca a independência nessas relações, talvez porque agora seja capaz de fazer coisas por e para si mesma. Durante esse processo, inclui-se, também, a centralização nos companheiros e o processo de identificação, como, por exemplo, algumas descobertas cognitivas a respeito das categorias menino e menina, o que conduz à compreensão do fato de que o sexo da pessoa é constante no decorrer da vida.

Ela se volta mais para os companheiros de sua idade e menos para os adultos. Sendo assim, surge um aumento na competição, na rivalidade, na agressão, mas também um aumento (especialmente no final deste período) do respeito para com os outros.

No domínio cognitivo, a criança faz progressos estáveis, diminuindo um pouco seu egocentrismo (operar como se sua própria forma de observar, experimentar e comportar fossem as únicas existentes), e desenvolvendo os rudimentos da classificação (agrupar objetos, eventos ou qualquer outra coisa e usar estes grupos consistentemente).

Durante esse período a linguagem mostra progressos marcantes. Aos 2 anos, a criança possui apenas rudimentos de linguagem e, aos 5 anos, ela se torna extremamente habilidosa no uso de sua língua nativa.

A criança raciocina do específico para o específico: duas coisas juntas são tomadas como tendo uma relação causal. Piaget dá um exemplo: Lucienne, numa tarde em que ela não havia tirado uma soneca, anunciou que: "Eu não tirei minha soneca, então não é tarde”. A tarde e a soneca usualmente ocorriam juntas, mas a relação que ela estabeleceu entre elas era errada.

\subsubsection{Dos 5 aos 7 anos}

Nesse período as principais mudanças aparecem no domínio cognitivo. São dominadas várias habilidades de classificação, por exemplo, uma classe subordinada é percebida como parte de uma classe maior; e a reversibilidade (capacidade de compreender que a subtração é 
o inverso da soma, por exemplo) é compreendida. Outras ações mentais mais complexas vão se desenvolvendo como adição, subtração e seriação (desenvolve-se a capacidade de dispor em ordem mais de quatro coisas em seqüência). Mas, nesse estágio, as operações ainda são concretas, baseadas com experiências particulares. A criança ainda não consegue pensar sobre o pensamento ou imaginar coisas que não tenha experimentado.

Nesse período, o conceito de transitividade também é compreendido. Por exemplo, se Jane é mais alta do que Sara e Sara é mais alta do que Ana, então Jane é mais alta do que Ana. Os conceitos de conservação ${ }^{9}$ de substância, de conservação de número e de conservação de tamanho são adquiridos primeiro, aproximadamente aos 6 ou 7 anos.

A criança de 5, 6 ou 7 anos começa a usar a linguagem para ajudá-la a pensar. Se, por exemplo, se pede para uma criança memorizar uma série de números ou figuras, ela ficará repetindo verbalmente a série a si própria, até que se peça que repita em voz alta. Há algumas sugestões relativas a uma mudança na percepção, de uma confiança primária no tato e sentimentos para uma confiança primária na visão.

Geralmente a criança começa a freqüentar a escola com essa idade, o que significa que há um enorme aumento do tempo gasto com os companheiros, bem como uma centralização na aprendizagem formal. Por esta idade, também, o grupo de companheiros do mesmo sexo estabeleceu-se fortemente como um padrão.

\subsubsection{Dos 7 aos 12 anos}

Um outro período de consolidação ocorre entre as idades de 7 a 12 anos. A habilidade de classificação torna-se mais complexa e a criança é capaz de compreender a classificação múltipla, isto é, um determinado objeto pertencer a mais de uma categoria ao mesmo tempo, um pequinês pode ser tanto um cachorro como um animal, por exemplo.

9 Conservação: o principio fundamental é que certas propriedades dos objetos - sua quantidade, número, peso, etc permanecem inalteradas, mesmo quando se modifica sua forma ou disposição espacial. 
O conceito de conservação de peso vem aproximadamente aos 8 anos de idade e o de conservação de volume e de área por último, aproximadamente aos 10 anos.

A criança de 8 ou 9 anos pode encontrar uma resposta por acaso, enquanto uma criança mais velha pensa nas possibilidades e as testa a fim de selecionar as que sejam mais úteis.

A criança continua a crescer, mas o ritmo de crescimento é muito mais lento do que antes. O relacionamento com os companheiros permanece bastante centrado nos grupos de mesmo sexo e há poucas mudanças durante o período. As mudanças perceptuais também não mudam de modo significante.

Entre os 11 ou 12 anos, a mudança fundamental é que a criança não permanece mais ligada ao concreto. Ela dispõe das mesmas operações (somar, dividir, multiplicar, subtrair), mas pode fazê-las “de cabeça”.

\subsubsection{Os Efeitos da pobreza no desenvolvimento}

Em uma citação de Helen Bee (1977) sobre Herbert Ginsburg, relata-se que:

Crianças pobres não são diferentes quanto à competência cognitiva fundamental ou capacidade - que estas crianças têm todos os tipos necessários de pensamento e habilidades de solução-de-problema que as crianças de classe média.

Acredita-se que a seqüência de desenvolvimento cognitivo para todas as crianças é a mesma, independentemente da sua condição econômica. O desempenho pode variar em função de outros fatores, como motivação, mas as competências fundamentais e as habilidades cognitivas de base são as mesmas.

Um aspecto que pode sofrer alteração é a velocidade que o desenvolvimento apresenta, havendo um ligeiro atraso na progressão do desenvolvimento das crianças pobres. Acredita-se que essas diferenças provêm, em parte, de diferenças na saúde e nutrição inicial. 


\subsection{Personagens}

\subsubsection{O que é um personagem?}

Os personagens são imagens criadas (graficamente ou pela imaginação) que participam do universo da criança. Eles surgem nesse universo imaginário de diversas origens: das histórias contadas pelos pais, dos filmes, dos desenhos animados, do universo em quadrinhos, dos produtos de consumo, de jogos infantis, de campanhas, entre outros. Essa origem não qualifica o personagem com maior ou menor importância, em um primeiro momento. Todos se inserem no universo infantil com a mesma oportunidade de relacionar-se com a criança.

Esses personagens podem apenas existir no imaginário da criança (personagens criados, imaginados por elas) ou existirem de fato, desenhados, terem sido criados para comunicar-se com as crianças. Aprofundaremos, em seguida, sobre os personagens projetados (desenhados) para o público infantil.

Os personagens que participam mais do dia-a-dia da criança são os de desenho animado e de jogos com que ela está acostumada a brincar. Em uma parcela menor, participam também os personagens de histórias infantis e histórias em quadrinhos. Há personagens que não se inserem diretamente no cotidiano das crianças, mas são de fundamental importância em diversos momentos, podendo também conviver com a criança se houver incentivo nesse sentido pelo personagem. Esses personagens são aqueles mais tematizados (orientados), conversam com a criança sobre temas específicos quando é necessário. Como exemplo, pode-se citar os personagens da escola, para ensinar a tabuada na matemática; os personagens de produto de consumo, para vender o produto e toda a promessa do personagem; ou os personagens de campanhas, como de saúde ou de doação de livros.

Um personagem muito conhecido pelas crianças e adultos em geral, no tema saúde, é o “Zé Gotinha”, criado em 1986, pelo artista plástico Darlan Rosa, mineiro radicado em Brasília. O Ministério da Saúde realizou um concurso nacional para que o personagem 
ganhasse um nome, e crianças do Brasil inteiro escolheram Zé Gotinha, o personagem da Campanha Nacional de Vacinação contra a Paralisia Infantil criado para incentivar e ajudar na vacinação das crianças.

Figura 3.2 Personagem “Zé Gotinha”

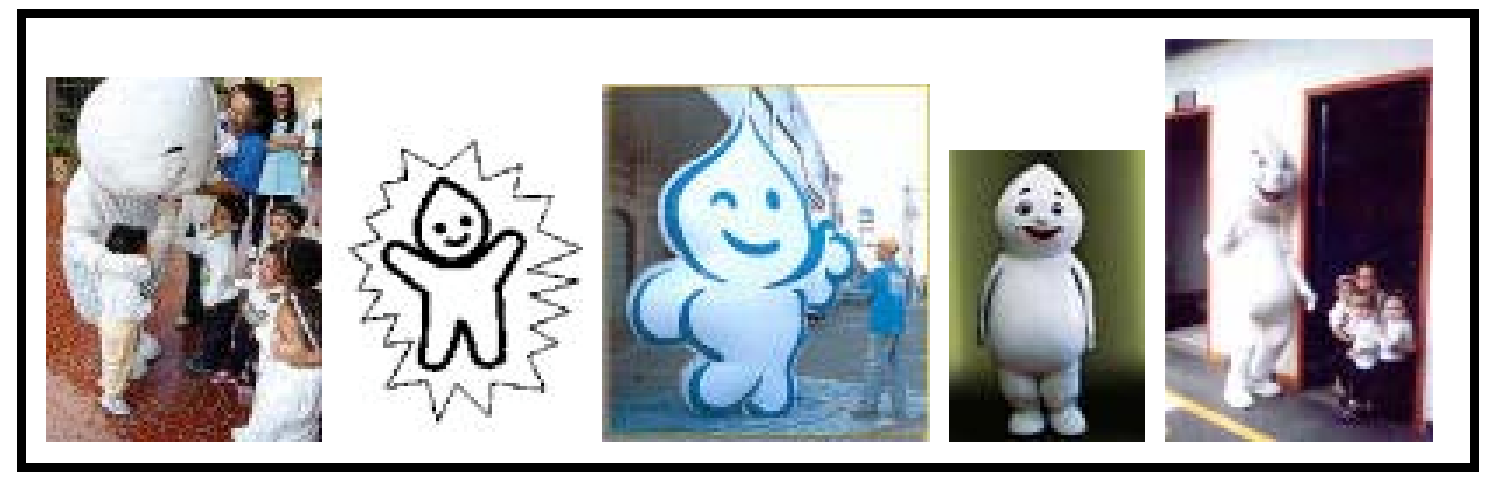

Desde então, o Zé Gotinha se tornou o símbolo da campanha, que ajudou a erradicar a paralisia infantil (ou poliomielite) e a manter o vírus causador da doença afastado do país. Anos mais tarde, o personagem foi adotado também para outras vacinas infantis, com uma cor diferente para cada uma: branco contra a poliomielite; vermelho contra o sarampo; azul marinho para a vacina contra a tuberculose; azul claro para a da coqueluche; laranja para difteria, e verde para o tétano. As campanhas animadas pelo personagem Zé Gotinha levaram à imunização de $96 \%$ dos brasileiros de até 5 anos. Esse é um dado muito importante para perceber a importância de um personagem em uma campanha. Houve uma mobilização nacional e a presença do Zé Gotinha foi essencial.

Sua forma está totalmente associada à vacina em gotinha. O Zé Gotinha é a própria gota da vacina da criança. O “Zé Gotinha” têm formas muito simples e diretamente associada à vacina das crianças. Seu rosto também simplório fez a comunicação com a criança ser muito direta, clara, objetiva e ao mesmo tempo, com muita afetividade. Ele é todo branco. Por ser a vacina, traz todo o conceito de limpeza e saúde muito facilmente associado à sua cor. Seu nome, também diretamente ligado à vacina, aproxima ainda mais a relação da criança com o personagem e sua função, incentivar a vacina. 
Outro personagem conhecido, que atua em diversos temas infantis, por uma causa social, é o "Senninha”.

Senninha nasceu inspirado no então bi-campeão de fórmula 1 Ayrton Senna. Fruto da admiração de seus criadores, Rogério Martins e Ridaut Dias Jr, pelo piloto, o personagem começou a surgir em 1990. Fãs de fórmula 1, os dois tiveram a idéia de levar a imagem do piloto para as histórias em quadrinhos. Com a certeza de que um personagem com as características de Ayrton teria uma boa aceitação junto ao público infantil, Rogério e Ridaut criaram primeiramente o personagem, em seguida seu universo, sua turma, e como não poderia deixar de ser, seus rivais. A idéia precisava passar para o papel. Nascia um projeto campeão. ${ }^{10}$

Figura 3.3 Personagem “Senninha”

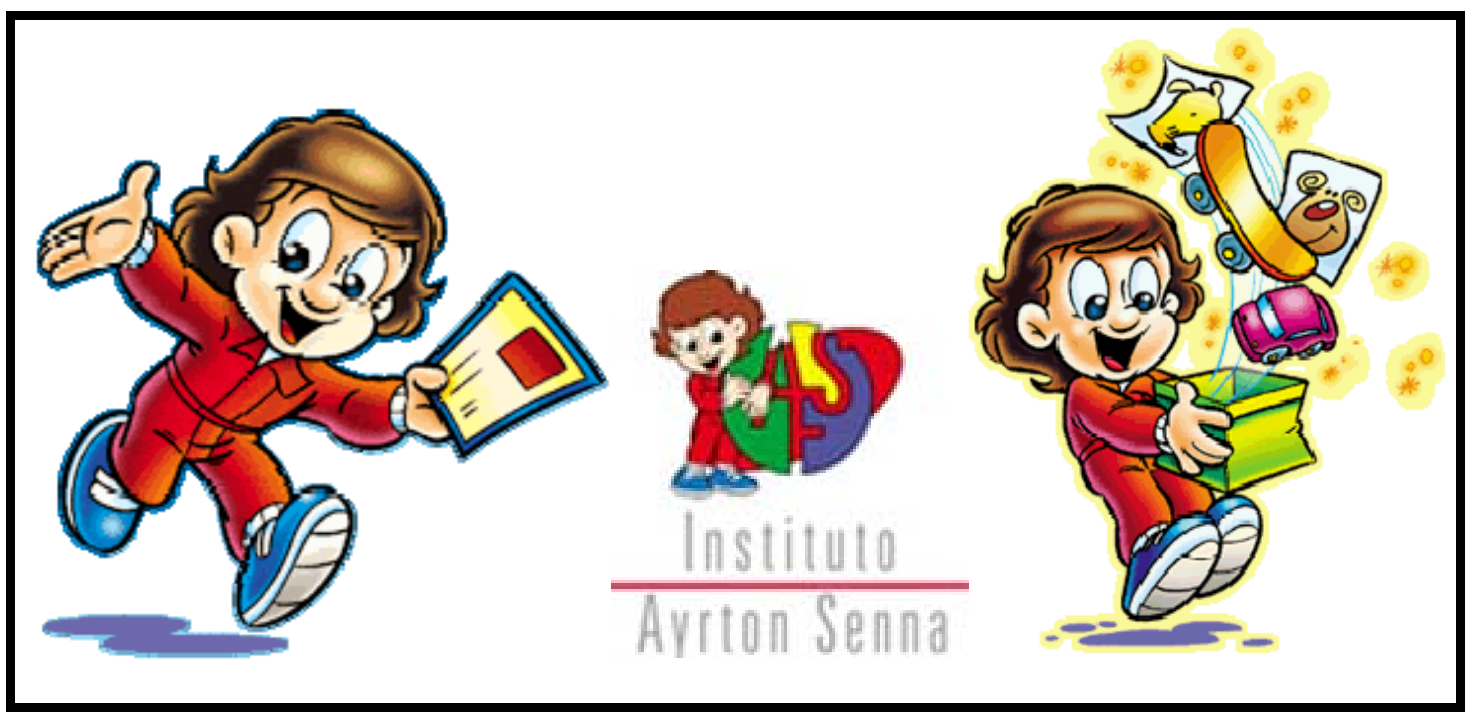

A forma do "Senninha” é o próprio Ayrton Senna, porém criança. O Senninha é o Ayrton Senna caricaturizado e infantilizado. O personagem humano ajuda a trabalhar valores morais diferente.

\subsubsection{Personagem $x$ imaginário da criança}

É muito importante entender a relação da criança com os personagens imaginários. Entendendo essa relação, consegue-se perceber a importância de um personagem para falar qualquer assunto à criança. Seja qual for a informação, se passada por um personagem, terá maior chance de ser aceita, compreendida e assimilada.

\footnotetext{
${ }^{10}$ http://senna.globo.com/senninha/
} 
Tudo é permitido (e possível) no imaginário da criança. A criatividade, as possibilidades de associações, idéias, formas, cores, sentimentos, enfim, tudo é controlado pela criança, e esta não encontra limites na imaginação.

Um aspecto muito relevante é compreender o que o personagem significa para a criança. Após estudos realizados, observou-se a maneira como as crianças referem-se aos personagens, como se fossem pessoas reais. As crianças os descrevem personificando-os, mesmo que o personagem seja um animal, ou o próprio Zé Gotinha (uma gota), apresentado anteriormente. Essa observação mostra que os personagens realmente fazem parte do cotidiano da criança, além de manter relações próximas e amigáveis. O personagem é mais um amigo, colega da criança. Ele não está fora e nem longe das ações da criança. Ele participa e está sempre presente nas brincadeiras.

Percebe-se, então, o quanto é importante o quê que o personagem passa à criança. Essa informação tem o mesmo valor de uma informação passada pelo seu melhor amigo. O personagem tem uma responsabilidade muito grande por ter essa relação tão próxima com a criança.

É claro que, para essa relação ser dessa forma, o personagem deve cativar a criança, envolvê-la, ganhar e manter sua atenção. Esse assunto será abordado em seguida, em “Como criar um Personagem?”.

O personagem, em muitos casos, propõe um modelo a ser seguido pela criança. Normalmente são heróis de desenhos animados. Um estudo realizado por Chombart de Lauwe e Bellan resume bem a dificuldade e ambigüidade do relacionamento no confronto da criança com o modelo de personagem proposto:

Ora elas (as crianças) se sentem inferiorizadas pela comparação com o herói demasiado poderoso, que sempre é bem-sucedido e se beneficia de uma situação particularmente atraente; ora elas se servem dele como mediador entre seu status de criança e um novo status de mais autonomia, mais próximo do status de adulto. Incapazes de se tornar o herói, elas aspiram a se parecer com ele, elas o imitam, adotam alguns dos seus comportamentos ou ainda se imaginam confortadas pela sua presença, que as ajuda a se transformar. (MONTIGNEAUX, 2003, p. 110) 
Também é válido citar a existência dos personagens com características más. Normalmente as crianças não se identificam com esses personagens, mas eles também são eficazes na passagem de informação. Quando há uma diferença muito clara entre o personagem bom e o personagem mau, muito freqüente em contos de fada, a criança quer ser o herói da história, o bom torna-se seu melhor amigo. Conseqüentemente, suas ações serão projetadas na vida da criança. Já as ações do personagem mau não serão bem vistas, claramente, fazendo com que a criança não tenha atitudes iguais ou parecidas. Em diversos momentos essa diferença entre os personagens mostra-se muito importante para a criança. A informação positiva fica ainda mais clara quando contrastada com a informação negativa.

Finalmente, o personagem é um modelo inspiracional que deve ajudar, conduzir a criança para o status de adulto. É pelo fato de o personagem propor à criança um modelo de comportamento e um conceito que o processo de identificação poderá ocorrer. Ao longo do processo de identificação, a criança encara o personagem segundo duas dimensões: o prazer e o dever.

\subsubsection{Como criar um personagem?}

Há pesquisas realizadas com as crianças que visam perceber o que mais as atraem nos personagens. As pesquisas abaixo evidenciam a importância do físico e jeito do personagem.

Um estudo realizado por Brissy entre crianças de idades de 7 a 8 anos apresentou com precisão as seqüências de descrições de personagens de marca, presentes nas embalagens de produtos de grande consumo. O estudo segue uma ordem bastante precisa, partindo do exterior do personagem (seus traços físicos) até a evocação de sua personalidade.

As crianças descrevem os personagens na seguinte ordem:

- Seus traços físicos (cor, vestimenta...)

- Sua atitude, seu comportamento, exprimindo uma ação (correr, saltar) ou um sentimento (sorrir);

- Seu caráter, sua personalidade e suas relações com as crianças (alegres, esportivas, gentis...).

O resultado de um estudo realizado por Reason Why Kid ("É este um personagem?”) identificam as principais razões da atração dos personagens junto às crianças.

O personagem é visto e apreciado pela criança por meio de várias dimensões: 
- personagem é engraçado, simpático (com efeito, é associado, muitas vezes, aos jogos e às brincadeiras). A dimensão lúdica é a mais importante;

- personagem acompanha a criança durante todo o dia. É uma companhia fiel;

- personagem representa um universo imaginário. Ele traz para a criança uma dimensão mágica através de seus poderes ou suas capacidades físicas ou intelectuais excepcionais que permitem à criança fuga do seu cotidiano. (MONTIGNEAUX, 2003, p. 105)

São os aspectos apresentados acima que chamam a atenção da criança. O que mantém essa atenção, é, principalmente, a coerência desses personagens, na sua forma física, atitudes e personalidade. Os incentivos dos personagens a estarem o mais próximo possível do dia a dia da criança só serão válidos se houver coerência. A criança estabelece essa relação com a repetição, que cria a confiança no personagem.

Para criar um personagem, deve-se, primeiramente, ter um objetivo. Em um segundo momento, para alcançar o objetivo, deve-se definir que conceitos estão agregados nos personagens, para conseguir apresenta-los graficamente.

A criança perceberá inconscientemente os conceitos agregados nos personagens de acordo com sua forma física e atitudes. A análise física do personagem traduz o sentimento e os caracteres profundos que o animam. Assim, abaixo há um quadro de elementos gráficos de personagens, alguns exemplos que demonstram a maneira pela qual as crianças intuitivamente decodificam essas características.

Quadro 3.1 Conceitos e características decodificadas pelas crianças.

Fonte: livro "Público Alvo: Crianças - A força dos personagens e do marketing para falar com o consumidor infantil” de Nicolas Montigneaux

\begin{tabular}{|l|l|}
\hline $\begin{array}{l}\text { Partes do } \\
\text { personagem }\end{array}$ & Conceitos e características decodificadas pelas crianças \\
\hline Cabeça & $\begin{array}{l}\text { O tamanho da cabeça indica o caráter, a idade e a capacidade de } \\
\text { pensamento (quanto maior a cabeça, maiores essas características). } \\
\text { Inversamente, personagens de cabeças pequenas podem ser } \\
\text { desvalorizados. Junto com os olhos e as orelhas, o tamanho da cabeça } \\
\text { também é um meio de comunicação por excelência; }\end{array}$ \\
\hline
\end{tabular}




\begin{tabular}{|c|c|}
\hline Olhos & $\begin{array}{l}\text { Os olhares são fonte principal de expressão do rosto, por isso a } \\
\text { importância em defini-los claramente. Um personagem corajoso olha } \\
\text { de frente e de lado e não baixa os olhos. Ele mostra os dois olhos } \\
\text { completamente; }\end{array}$ \\
\hline Воса & $\begin{array}{l}\text { Mais importante para as crianças menores, a boca indica a mamadeira, } \\
\text { o polegar. Elas exploram tudo com a boca; }\end{array}$ \\
\hline Sobrancelhas & $\begin{array}{l}\text { Harmoniosas, definidas - as sobrancelhas indicam a preocupação de } \\
\text { autocontrole e espessas, eriçadas traduzem um sentimento de raiva ou } \\
\text { dificuldade de reprimir seus instintos; }\end{array}$ \\
\hline Nariz & $\begin{array}{l}\text { Pela sua forma é um símbolo fálico. Traduz virilidade (reforçados com } \\
\text { o vestuário, como uma gravata ou boné); }\end{array}$ \\
\hline Mãos & $\begin{array}{l}\text { Definem a idade a que o personagem se dirige (personagens para } \\
\text { crianças com menos de seis anos têm quatro dedos). As mãos grandes } \\
\text { em relação ao corpo indicam desejo de exploração, de ação e } \\
\text { sociabilidade. Sua disposição indica acompanhamento. As mãos são } \\
\text { claramente um convite para a criança entrar na imagem e se deixar } \\
\text { abrigar por ela; }\end{array}$ \\
\hline $\begin{array}{l}\text { Pernas e } \\
\text { Braços }\end{array}$ & $\begin{array}{l}\text { Braços franzinos enviam para a criança a imagem de sua própria } \\
\text { fraqueza. Pernas menores que o tronco indicam a idade do personagem } \\
\text { (mais novo); }\end{array}$ \\
\hline Pés & $\begin{array}{l}\text { Achatados e com contorno definido indicam personagens que têm “o pé } \\
\text { na terra”. Pés grandes e afastados dão idéia de estabilidade e ajudam a } \\
\text { equilibrar o tamanho da cabeça; }\end{array}$ \\
\hline Acessórios & $\begin{array}{l}\text { São os valores simbólicos para a construção da personalidade e do } \\
\text { caráter. Seu vestiário, objetos que carregam são pontos preciosos para a } \\
\text { criança e significam familiaridade e proximidade com o personagem; }\end{array}$ \\
\hline Vestuário & $\begin{array}{l}\text { Mais importante a partir dos } 4 \text { ou } 5 \text { anos, agrega valor social. Nudez } \\
\text { passa a ser punição ou humilhação. Roupas macias e amplas traduzem } \\
\text { descontração e liberdade; }\end{array}$ \\
\hline
\end{tabular}




\begin{tabular}{|c|l|}
\hline Força Física & $\begin{array}{l}\text { As crianças são fascinadas pela força física, mas somente se } \\
\text { acompanhada pela inteligência, astúcia, conhecimento e sabedoria; }\end{array}$ \\
\hline Forma Geral & $\begin{array}{l}\text { Curvas - indicam idade mais nova, mais carinhosos, contêm a } \\
\text { agressividade. Angulosas - traduzem certa agressividade. }\end{array}$ \\
\hline
\end{tabular}

No geral, a simplicidade dos traços e os conceitos dos personagens são muito valorizados. Quanto mais simples é o personagem, mais a leitura da sua personalidade é facilitada para a criança, mas ela poderá com ele se identificar. Novamente, a importância da coerência nos atos e formas dos personagens também facilita a identificação.

\subsection{O Brincar infantil}

\subsubsection{Por que a criança brinca?}

Quando falamos em criança, é impossível não falarmos do brincar, não só pelo aspecto lúdico que caracteriza essa fase, mas também pela grande importância que o brincar tem na preparação da criança para vida futura. É através das brincadeiras que a criança descobre suas capacidades e habilidades e pode, dessa forma delinear e fixar uma diretriz vocacional.

Com as brincadeiras, a criança imita, joga, brinca, experimenta enriquecendo suas experiências individuais, ampliando seu contato com o mundo que a cerca, descobrindo novidades, desenvolvendo habilidades, estabelecendo relações e cultivando sua inteligência.

É justamente pensando no desenvolvimento infantil como um todo que devem ser propostos jogos e brincadeiras que ajudem nesse sentido. O brinquedo, além das funções de dar prazer, desenvolver a inteligência e a motricidade, de aprender a realidade, prepara para uma atividade produtiva, inicialmente para si mesmo, depois para a sociedade.

Por exemplo, ao dar à criança a oportunidade de brincar, estamos formando nela a socialização. Ao apresentar-lhe metodicamente atividades, estamos proporcionando-lhes a 
formação do senso de horário e trabalho. Os jogos de bola formam o gosto pelo esporte e pela competição. Ao colocá-la em contato com a jardinagem, ela criará amor pela natureza, além do desenvolvimento do aspecto motor.

Através da forma que a criança brinca, é possível observar suas atitudes em relação ao ambiente e sua maneira de agir e reagir com os demais. O brinquedo traz uma vivência de um prazer específico intenso, o que indica que brincar é uma necessidade básica da criança como instrumento de seu desenvolvimento.

Além disso, de acordo com Vânia Dohme ${ }^{11}$ :

Começa-se a acreditar que, para as crianças em geral e para as excluídas e desfavorecidas, em particular, as atividades lúdicas podem ser uma das poucas atividades que criam situações onde as desvantagens e as desigualdades sociais e culturais se atenuam ou mesmo se dissipam. O brincar faz parte de um processo de aculturamento para crianças de diferentes origens, por meio do qual elas estabelecem contato e fazem trocas de experiências e pontos de vista. (DOHME, 2003, p. 14)

Com o jogo, pode-se trabalhar o desenvolvimento físico, intelectual, artístico criativo, dos sentidos, afetivo, social e ético. Ele também colabora tanto no aperfeiçoamento físico, como na destreza, no equilíbrio e acuidade dos sentidos, como no aperfeiçoamento mental, desenvolvendo a atenção, a memória, o raciocínio e a lógica e, ainda, no aperfeiçoamento do relacionamento social, como o convívio com regras e a vida em equipe. (DOHME, 2003, p. 21)

A criança passa a ser o centro da ação e, a partir daí, ela se reconhece e reconhece os demais, entre maneiras de usar as suas habilidades, superar suas limitações, conhecer o próximo, fazer acordos, interagir buscando o melhor de cada um a fim de alcançar o desafio proposto. (DOHME, 2003, p. 22)

\subsubsection{O Jogo na educação e no hospital}

Na escola, manipulando e brincando com materiais como bolas e cilindros, montando e desmontando cubos, a criança estabelece relações matemáticas e adquire conhecimentos de Física e Metafísica, além de desenvolver noções estéticas. Isso acontece, porque através do jogo, brincando a criança torna concreto um conceito abstrato, tornando muito mais fácil a compreensão e assimilação.

O jogo, por ser livre de pressões e avaliações, cria um clima adequado para a investigação e busca de soluções. O benefício do jogo está nessa possibilidade de estimular a

11 Vania D'Angelo Dohme é mestre em Educação, Cultura e Arte pela Universidade Presbiteriana Mackenzie. Sua formação é completada por diversos cursos técnicos em ludoeducação, capacitação de líderes e equipes e protagonismo social no Brasil e no exterior. É pesquisadora do uso do lúdico na educação, tendo trabalhado nesta área há 30 anos. 
exploração em busca de respostas, em não constranger quando se erra. Nesse caso, o erro pode estimular ainda mais a busca por novas respostas.

De acordo com a literatura, o jogo é importante por seu potencial para o aprendizado moral, integração da criança no grupo social e como meio para aquisição de regras. Considera-se que as habilidades e conhecimentos adquiridos no jogo preparam para o desempenho para a vida adulta. De acordo com Vânia Dohme, a mais interessante característica do jogo é que, dentro deste ambiente fechado e assumido livremente, os jogadores experimentam múltiplos sentimentos e experiências educativas diferentes, que podem ser usadas na vida cotidiana.

No hospital, os objetivos na utilização do jogo também não são muito diferentes. Nesse ambiente, os jogos têm várias funções: a de entreter a criança no momento de espera, a de ensinar novos conceitos e novos hábitos e a de tentar trazer à tona as sensações e sentimentos das crianças em relação ao hospital, ao tratamento e aos médicos. Dessa forma, todas as reflexões sobre jogo feitas para os jogos aplicados na escola podem também ser aplicadas no hospital.

Devido a toda sua importância dentro do ambiente hospitalar, o jogo que será proposto como objeto final deste projeto abordará todos esses aspectos, mas terá principalmente o objetivo de facilitar a aquisição e compreensão de novos conceitos e novos hábitos, reforçando ainda mais os conceitos e informações transmitidos pelas explanações nos grupos informativos.

\subsubsection{Jogo Cooperativo}

Nos Jogos Cooperativos, a ação cooperativa das crianças é necessária para se atingir um objetivo comum a todos. Os participantes jogam uns com os outros e não contra. Joga-se para juntos superar desafios e compartilhar o sucesso. O confronto é eliminado e dá lugar ao encontro, à união das pessoas, à eliminação do medo e do fracasso. 
Os princípios dos Jogos Cooperativos foram desenvolvidos por Terry Orlick, psicólogo canadense que na década de 70 constatou que os jogos reproduziam a estrutura social, refletindo valores da sociedade.

Os Jogos Cooperativos são estruturados para diminuir a pressão para competir e a necessidade de comportamentos destrutivos, para promover a interação e a participação de todos, e deixar aflorar a espontaneidade e a alegria de jogar. São jogos de compartilhar, unir pessoas, que eliminam o medo e o fracasso e que reforçam a auto-confiança. Dessa forma os Jogos Cooperativos resultam no envolvimento total, em sentimentos de aceitação e vontade de continuar jogando.

\subsubsection{Alguns requisitos para o desenvolvimento do jogo}

Segundo a psicóloga do Hospital de Apoio, Sílvia Coutinho, a média das crianças atendidas está entre 7 e 8 anos de idade. Como visto no resumo do desenvolvimento infantil apresentado durante a descrição do público-alvo, durante cada estágio de desenvolvimento, há substanciais e importantes diferenças nas habilidades, na forma de aprendizagem, nas interpretações das sensações e dos estímulos e, conseqüentemente, diferentes formas de brincar são abordadas. Por esse motivo, a definição e desenvolvimento do jogo serão concentrados na faixa etária dos 7 e 8 anos. A seguir, serão apresentados, de acordo com a literatura, os tipos de brincadeiras dessa faixa de idade.

Para um bom desenvolvimento físico, são recomendadas as brincadeiras com bola (futebol, bater bola), bem como boliche, monta-pino. Em ambiente fechado, podem ser usados jogos de armar, colagem, pintura, recorte para formação de figuras, dobraduras. Devem ser fornecidos à criança lápis e desenhos para colorir, e ela deve copiar as cores. Para estimular a atenção, são úteis jogos da memória e dominó. A criança gosta também de histórias com marionetes. Ela própria chega a inventar as histórias. Nessa fase, a criança se interessa por discos de histórias e contos de fada. 
Levando-se em consideração que jogando e brincando a criança se desenvolve física e emocionalmente, ao mesmo tempo que mantém sua inteligência e seus reflexos ativos; pretende-se que o jogo funcione tanto como entretenimento para a criança no momento de espera e como ensinamento de novos conceitos, novos hábitos.

\subsection{Cores}

A cor dentro deste projeto terá duas e essenciais funções: a primeira delas é tornar todo o material visualmente atrativo e estimulante para pais e principalmente para as crianças; a segunda é distinguir os grupos de painéis pelas informações neles contidas. Para isso, então é importante a compreensão do significado psicológico das cores.

As cores constituem estímulos para a sensibilidade humana, influindo no indivíduo para gostar ou não de algo, para negar ou afirmar, para se abster ou agir. Mas muitas preferências e reações às cores são muito particulares e subjetivas e relacionadas a sensações passadas e a muitos outros fatores. Mesmo assim, os psicólogos estão de comum acordo quando atribuem certos significados a determinadas cores que são básicas para qualquer indivíduo que viva dentro da nossa cultura. Segue abaixo o esquema do significado das cores, retirado do livro Psicodinâmica das cores em Comunicação, p.112-115.

\subsubsection{Sensações acromáticas}

\section{Branco}

- Associação material: batismo, casamento, cisne, uno, primeira comunhão, neve, nuvens em tempo claro, areia clara.

- Associação afetiva: ordem, simplicidade, limpeza, bom pensamento, juventudade, otimismo, piedade, paz, pureza, inocência, dignidade, afirmação, modéstia, deleite, despertar, infância, alma, harmonia, estabilidade, divindade. 
- A palavra branco nos vem do germânico blank (brilhante). Simboliza a luz e nunca é considerada cor, pois de fato não é. Se para os ocidentais simboliza a vida e o bem, para os orientais é a morte, o fim, o nada. Representa também, para nós, ocidentais, o vestíbulo do fim, isto é, o medo ou representa um espaço (entrelinhas).

\section{Preto}

- Associação material: sujeira, sombra, enterro, noite, carvão, fumaça, condolência, morto, fim, coisas escondidas.

- Associação afetiva: mal, miséria, pessimismo, sordidez, tristeza, frigidez, desgraça, dor, temor, negação, melancolia, opressão, angústia, renúncia, intriga.

- Deriva do latim niger (escuro, preto, negro). Nós utilizamos o vocábulo “preto”, cuja etimologia é controvertida. É expressivo e angustiante ao mesmo tempo. É alegre quando combinado com certas cores. Às vezes tem conotação de nobreza, seriedade.

\section{Cinza}

- Associação material: pó, chuva, ratos, neblina, máquinas, mar sob tempestade.

- Associação afetiva: tédio, tristeza, decadência, velhice, desânimo, seriedade, sabedoria, passado, finura, pena, aborrecimento, carência vital.

- Do latim cinicia (cinza) ou do germânico gris (gris, cinza); nós utilizamos o termo de origem latina. Simboliza a posição intermédia entre a luz e a sombra. Não interfere junto às cores em geral. 


\subsubsection{Sensações cromáticas}

\section{Vermelho}

- Associação material: rubi, cereja, guerra, lugar, sinal de parada, perigo, vida, sol, fogo, chama, sangue, combate, lábios, mulher, feridas, rochas vermelhas, conquista, masculinidade.

- Associação afetiva: dinamismo, força, baixeza, energia, revolta, movimento, barbarismo, coragem, furor, esplendor, intensidade, paixão, vulgaridade, poderio, vigor, glória, calor, violência, dureza, excitação, ira, interdição, emoção, ação, agressividade, alegria comunicativa, extroversão.

- Vermelho nos vem do latim vermiculus [verme, inseto (a cochonilha)]. Desta se extrai uma substância escarlate, o carmim, e chamamos a cor de carmesim [do árabe: qirmezi (vermelho bem vivo ou escarlate)]. Simboliza uma cor de aproximação, de encontro.

Laranja (correspondo ao vermelho moderado)

- Associação material: outono, laranja, fogo, pôr-do-sol, luz, chama, calor, festa, perigo, aurora, raios solares, robustez.

- Associação afetiva: força, luminosidade, dureza, euforia, energia, alegria, advertência, tentação, prazer, senso de humor.

- $\quad$ Laranja origina-se do persa narang, através do árabe naranja. Simboliza o flamejar do fogo.

\section{Amarelo}

- Associação material: flores grandes, terra argilosa, palha, luz, topázio, verão, limão, chinês, calor de luz solar. 
- Associação afetiva: iluminação, conforto, alerta, gozo, ciúme, orgulho, esperança, idealismo, egoísmo, inveja, ódio, adolescência, espontaneidade, variabilidade, euforia, originalidade, expectativa.

- Amarelo deriva do latim amaryllis. Simboliza a cor da luz irradiante em todas as direções.

\section{Verde}

- Associação material: umidade, frescor, primavera, bosque, águas claras, folhagem, tapete de jogos, mar, verão, planície, natureza.

- Associação afetiva: adolescência, bem-estar, paz, saúde, ideal, abundância, tranqüilidade, segurança, natureza, equilíbrio, esperança, serenidade, juventude, suavidade, crença, firmeza, coragem, desejo, descanso, liberalidade, tolerância, ciúme.

- Verde vem do latim viridis. Simboliza a faixa harmoniosa que se interpõe entre o céu e o sol. Cor reservada e de paz repousante. Cor que favorece o desencadeamento de paixões.

\section{Verde-azulado}

- Associação afetiva: persistência, arrogância, obstinação, amor próprio, elasticidade da vontade.

\section{Azul}

- Associação material: montanhas longínquas, frio, mar, céu, gelo, feminilidade, águas tranqüilas. 
- Associação afetiva: espaço, viagem, verdade, sentido, afeto, intelectualidade, paz, advertência, precaução, serenidade, infinito, meditação, confiança, amizade, amor, fidelidade, sentimento profundo.

- Azul tem origem no árabe e no persa lázúrd, por lazaward (azul). É a cor do céu sem nuvens. Dá a sensação do movimento para o infinito.

\section{Roxo}

- Associação material: noite, janela, igreja, aurora, sonho, mar profundo.

- Associação afetiva: fantasia, mistério, profundidade, eletricidade, dignidade, justiça, egoísmo, grandeza, misticismo, espiritualidade, delicadeza, calma.

- $\quad$ Roxo vem do latim russeus (vermelho-carregado). Cor que possui um forte poder microbicida.

\section{Marrom}

- Associação material: terra, águas lamacentas, outono, doença, sensualidade, desconforto.

- Associação afetiva: pesar, melancolia, resistência, vigor.

- Marrom, do francês marron (castanho).

\section{Púrpura}

- Associação material: vidência, agressão, furto, miséria.

- Associação afetiva: engano, calma, dignidade, autocontrole, estima, valor.

- Púrpura deriva do latim purpura. Simboliza a dignidade real, cardinalícia.

\section{Violeta}

- Associação afetiva: engano, miséria, calma, dignidade, auto-controle, violência, furto, agressão. 
- Violeta é diminutivo do provençal antigo viula (viola). Essa cor possui bom poder sonífero.

\section{Vermelho-alaranjado}

- Associação material: ofensa, agressão, competição, operacionalidade, locomoção.

- Associação afetiva: desejo, excitabilidade, dominação, sexualidade.

\subsection{Tipografia infantil}

Os dados para escolha das fontes utilizadas no projeto foram retirados, principalmente, da pesquisa realiza na University of Reading, em Londres, Inglaterra. O Departamento de Tipografia e Comunicação Gráfica (Department of Typography \& Graphic Communication at The University of Reading) disponibiliza um site com informações sobre tipografia para crianças.

A pesquisa dessa universidade se baseia em dois aspectos: a fonte (forma da letra, do caractere) e o uso do espaço horizontal ou vertical. A tipografia depende da relação entre o tamanho, o entrelinhamento (espaço entre linhas), o kerning (espaço entre as letras), conseqüentemente, o comprimento da linha. Por essas razões não é possível afirmar que uma fonte, por si só, funciona melhor ou não para uma criança.

A pesquisa procura aspectos para que seja possível achar fontes que facilitem a leitura para a criança. Com esse objetivo, a pesquisa tem mostrado que a forma das letras, o estilo da fonte, o espaçamento entre letras e linhas e o comprimento da linha influenciam na escolha de uma fonte mais apropriada para a criança, focando na facilidade de leitura.

A pesquisa foi realizada em escolas primárias com 24 crianças em idade de leitura, cerca de seis ou mais de seis anos de idade. Um mesmo trecho de texto com caracteres e espaçamentos com as diferenças importantes para a pesquisa era passado às crianças para a leitura em voz alta na classe. As leituras foram gravadas e analisadas de acordo com o tempo 
da leitura, substituição de palavras ou letras, omissão da linha, palavra ou letra, inserção das mesmas, autocorreção, hesitação e repetição.

Conclusões baseadas na pesquisa, em opiniões de designers, editores e professores, testes de leitura para identificar quantos e quais tipos de erros quando as crianças lêem e opiniões de crianças sobre fontes e quais palavras elas usam para descrevê-las, indicam o seguinte:

- Os caracteres devem ter simplicidade na forma;

- Os caracteres ascendentes mais altos enfatizam a forma da palavra;

- Os caracteres devem ser de fácil distinção. Alguns caracteres, como o “a” e o “o”, dependendo da fonte, são facilmente confundidos;

- Não deve-se usar formas não usuais de caracteres;

- Fontes manuscritas ou que imitam a letra da criança não facilitam a leitura;

- Fontes com serifa ou sem serifa não apresentaram muita diferença nos resultados da pesquisa, porém $17 \%$ preferiram fontes sem serifa;

- Caracteres com algum traço mais infantil ou caracteres comuns também não apresentaram muita diferença, porém $13 \%$ das crianças preferiram fontes sem o traço infantil;

- O espaçamento entre palavras também não apresentou muita diferença, mas há uma preferência por palavras que se apresentam 70\% mais espaçadas que o normal;

- O espaçamento entre letras não apresentou diferença significante.

É importante explicar que as diferenças nas formas dos caracteres e nos espaços usados para essa pesquisa foram relativamente pequenas. Se uma criança apenas passasse o olho nesses textos não perceberia diferença alguma. Porém, a pesquisa mostra, sim, uma diferença na leitura e apresenta diversos comentários de crianças que perceberam essas diferenças assim como as palavras usadas. 


\section{DESENVOLVIMENTO DO PROJETO}

\subsection{Informações contempladas nos painéis de apresentação}

As informações dos painéis foram escolhidas após várias conversas com os profissionais de saúde do Hospital de Apoio. Os profissionais mais presentes neste processo de escolha foram a psicóloga doutora Sílvia Coutinho, a dentista Elizabeth Camilo e a médica doutora Raquel Toscano.

Os assuntos são diversos e amplos e, por conta disso, o nome da campanha foi escolhido. O nome “Amigos para sempre: a Saúde, o Cuidado e Você!” possibilita o trabalho em assuntos diversos focando na saúde e cuidados para com ela. Portanto, as informações justificam-se principalmente dessa forma: assuntos para cuidar da saúde da criança. Os assuntos podem ser básicos e pessoais como higiene básica, limpeza da casa e animais domésticos, como mais amplos como higiene no hospital e cuidados na internação. Pode, ainda, ser informações sobre as doenças, tratamento e remédios.

Para organizar as informações, uma divisão temática foi proposta. 


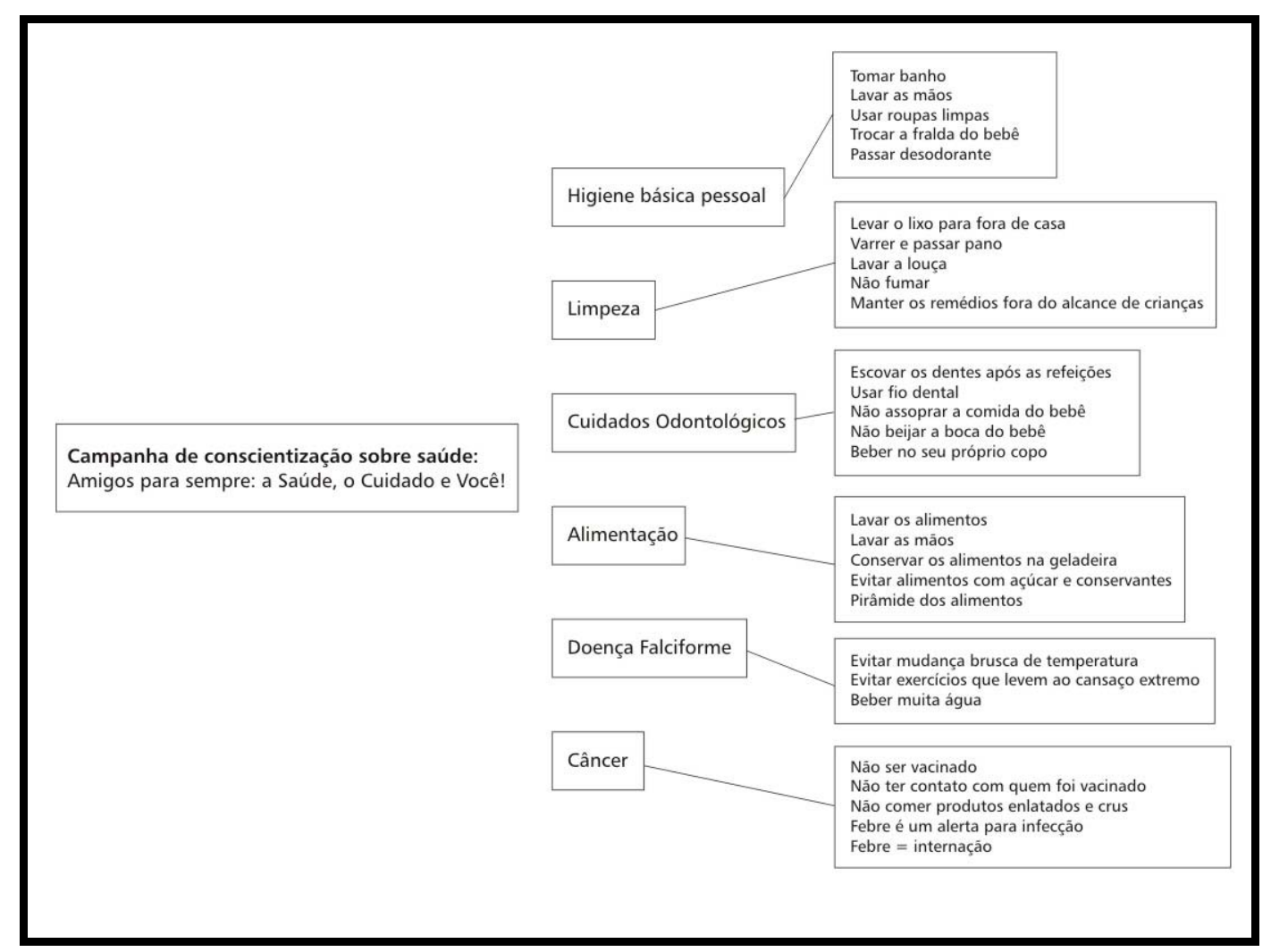

Assim, definidos os temas, higiene pessoal, limpeza, cuidados odontológicos, alimentação, doença falciforme e câncer, começou-se a pensar como esses temas estariam organizados nos painéis.

Para entender como as informações foram organizadas após serem tematizadas, deve-se entender onde os painéis serão usados, quais informações devem conter.

O principal lugar de uso dos painéis é o grupo informativo. O grupo informativo é um momento que acontece nas segundas-feiras de manhã, destinado principalmente aos pais, com o objetivo de informar sobre todas as mudanças na vida da criança e da família após o início do tratamento. 
Figura 4.1 Grupo informativo no Hospital de Apoio de Brasília.

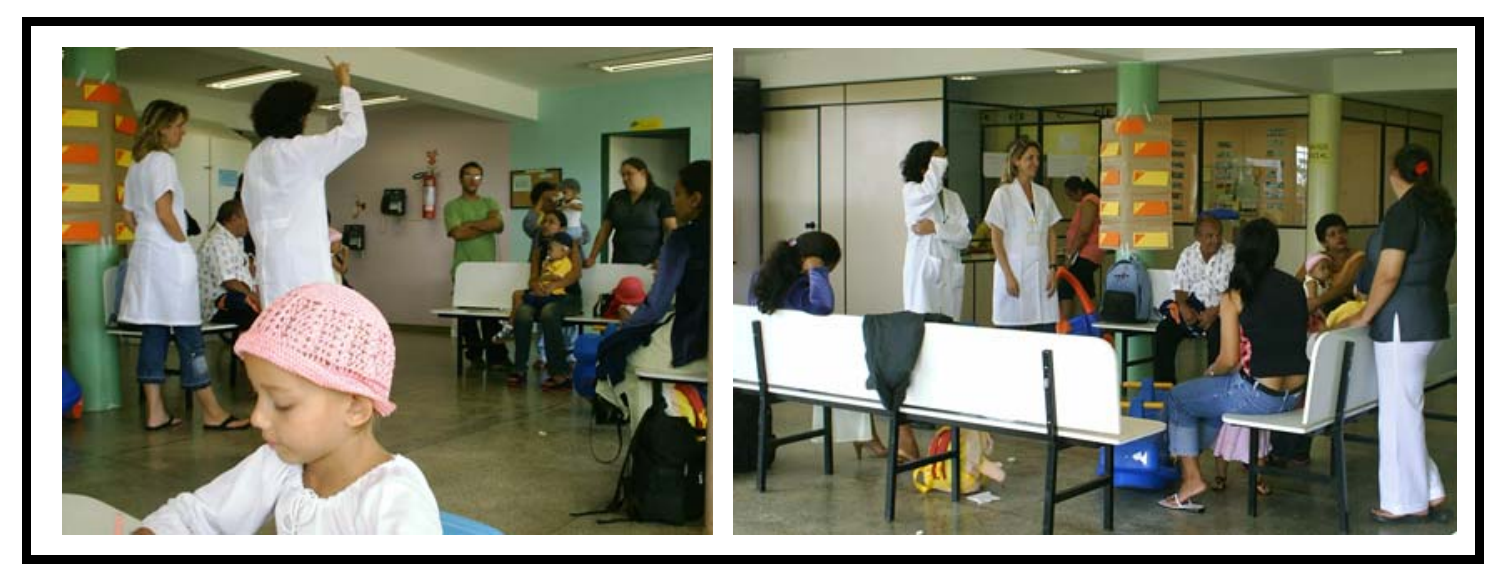

Esses grupos são informais e os assuntos o comentados a partir dos interesses e dúvidas dos participantes. A Dra. Sílvia Coutinho, psicóloga responsável do HAB, coordena esse grupo e esclarece as perguntas. Quando surge algum assunto mais específico ou que ela não sabe responder, Dra. Sílvia procura chamar outro profissional ou fica “devendo a resposta”, pesquisando-a e retornando posteriormente.

O único material de apoio usado é um cartaz com oito temas escondidos e assinalados com números. O objetivo desse cartaz é começar a conversa no grupo. Como no início todos ficam tímidos, é uma forma de começar um assunto. Os temas são, por exemplo, família, escola ou tratamento. Então um pai ou criança escolhe um número e de acordo com o tema a psicóloga fala das situações mais comuns até os pais começarem a participar, contar suas estórias, trazer suas dúvidas.

A Dra. Sílvia fala da dificuldade de, em diversos momentos, deixar claras algumas informações. Além do nível sócio-econômico e do grau de escolarização dos pais e crianças serem baixos, os termos técnicos das doenças e complexidades das mesmas dificultam a assimilação das informações. A Dra. Sílvia sente falta de recursos visuais, como ilustrações, para auxiliar a transmissão das informações.

Os painéis projetados neste trabalho serão usados nos grupos informativos como um material de apoio. Evidenciarão prioritariamente as ilustrações, justamente para suprir a 
demanda do grupo, facilitando o entendimento e assimilação das informações, tanto pelos pais como pelas crianças.

\subsection{Pesquisa de projetos visuais similares}

\subsubsection{Turma do Ique}

A “Turma do Ique” é um projeto gráfico desenvolvido no curso de desenho industrial da Universidade de Santa Maria, no Rio Grande do Sul.

Figura 4.2 Capa da cartilha da Turma do Ique

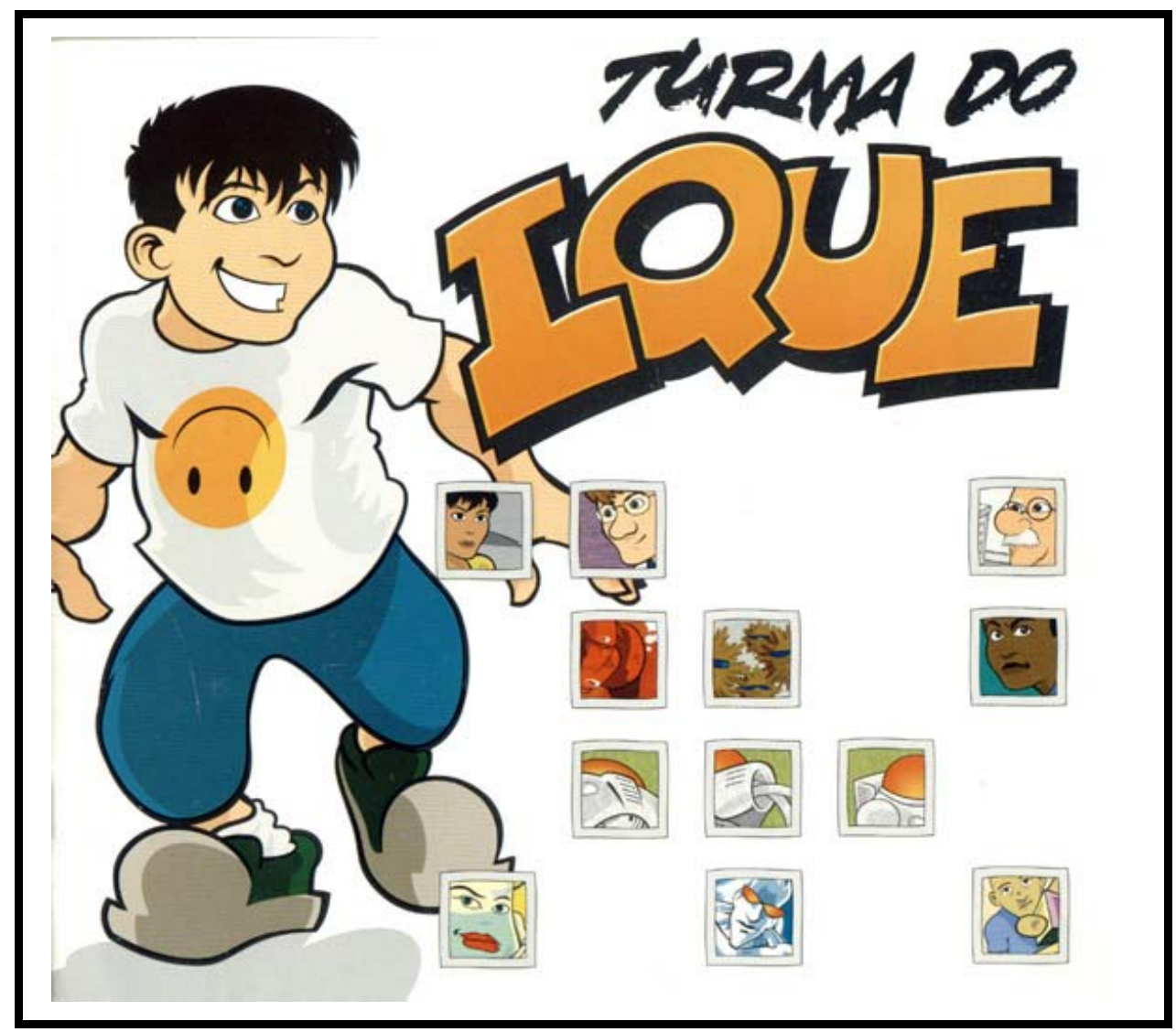

Junto com o personagem Ique, os seus amigos, os médicos e a família, o projeto pretende apresentar informações para as crianças que adquirem o câncer e começam os tratamentos, sobre a doença e processos os quais as crianças deverão ser submetidas ao longo do seu tratamento. A turma do Ique procura mostrar como pode ser bom e divertido tratar o câncer. 
Esse projeto desenvolveu uma cartilha, que pode ser vista nas figuras 4.2 e 4.3, além de um vídeo educativo e jornais com informações e brincadeiras para as crianças. Trata-se de um bom exemplo de projeto gráfico. As ilustrações têm um estilo próprio, que parece ser mais voltado aos adolescentes e menos infantil.

Figura 4.3 Página interna da cartilha da turma do Ique

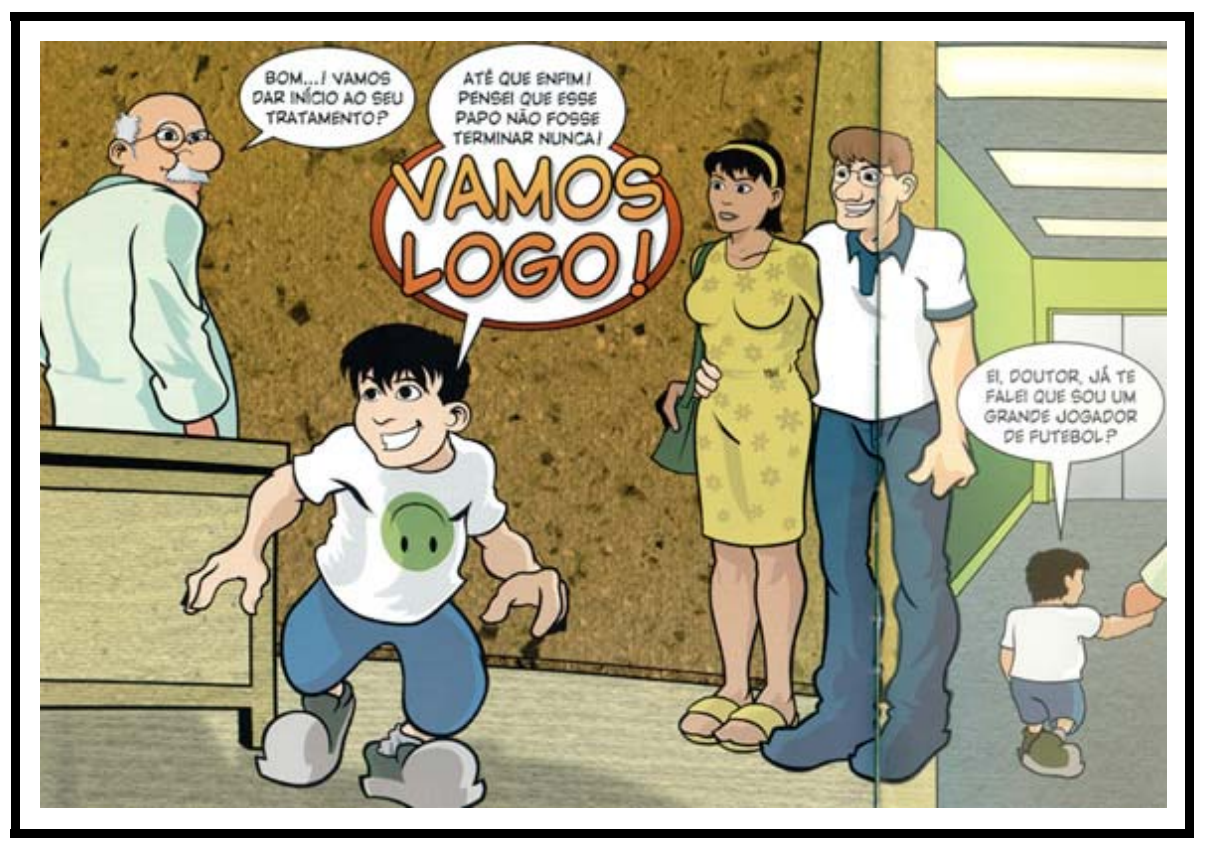

\subsubsection{Rede Infanto-Juvenil de Informações sobre o Câncer}

A Rede Infanto-Juvenil de Informações sobre o Câncer existe desde 2003. Seu objetivo é esclarecer quaisquer tipos de dúvidas em relação à criança com câncer. 
Figura 4.4 Página inicial do site da Rede Infanto-Juvenil de Informações sobre o Câncer

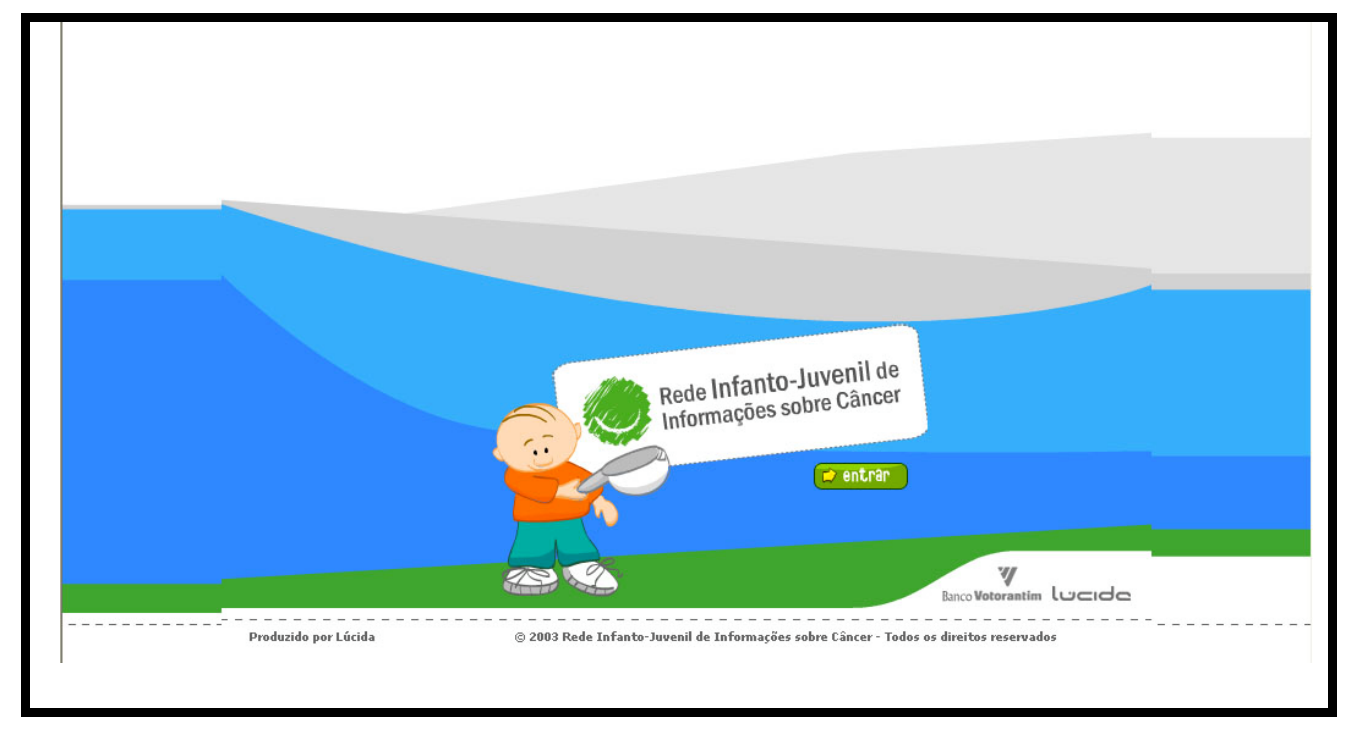

Figura 4.5 Página onde o usuário escolhe como quer entrar na Rede Infanto-Juvenil de Informações sobre o Câncer

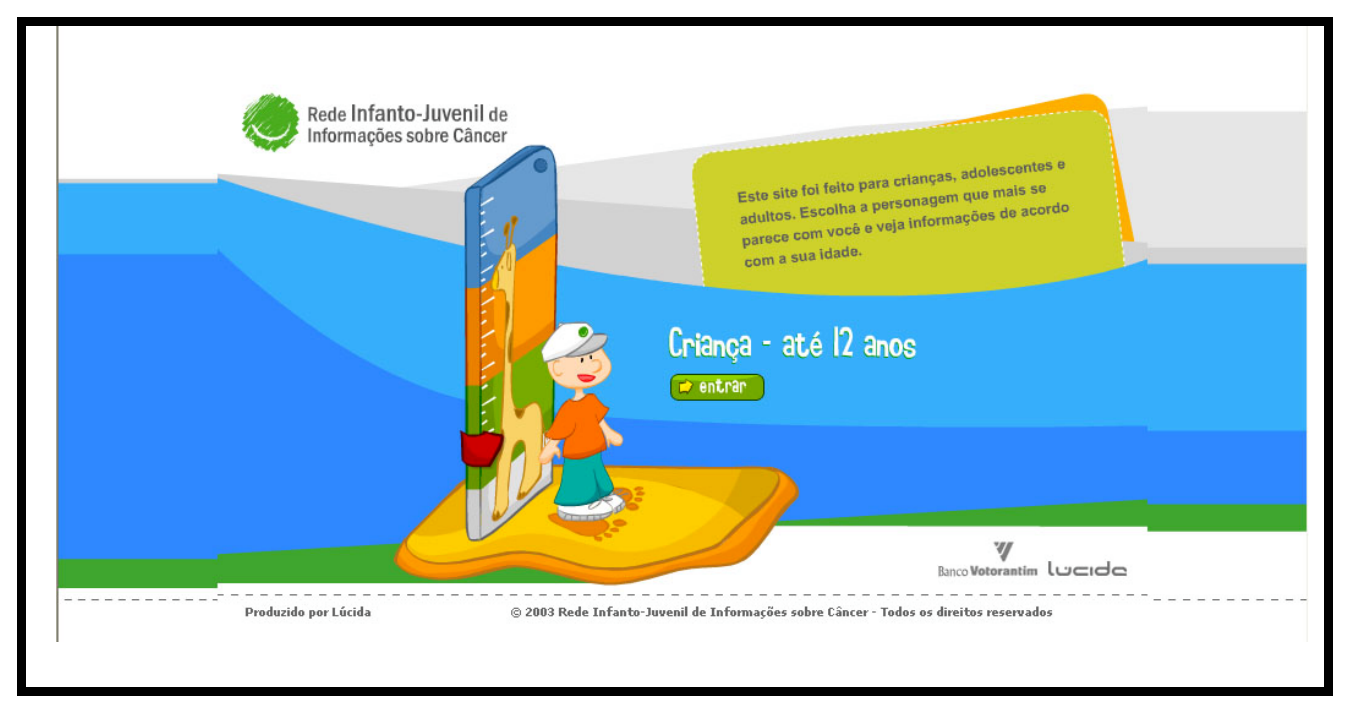

Essa informação só é acessada por uma página da internet, onde o usuário pode escolher como pode entrar na rede de informações. Há as opções: crianças, adolescentes e pais. É interessante observar que a linguagem visual é a mesma, mudando apenas os focos das dúvidas. 
Figura 4.6 Exemplo de uma página interna da Rede Infanto-Juvenil de Informações sobre o Câncer

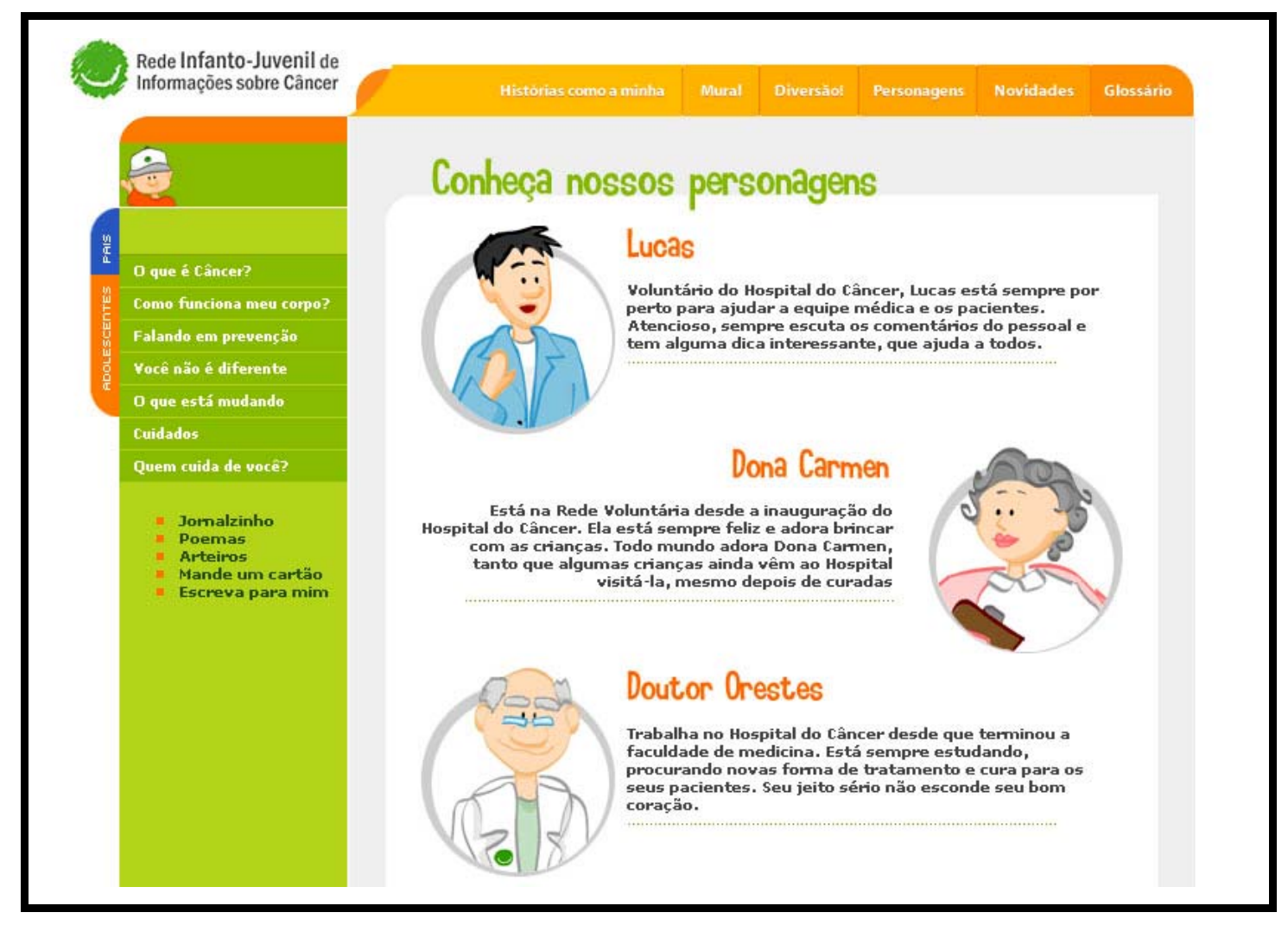

De acordo com a pesquisa de projetos similares, a Rede Infanto-Juvenil de Informações sobre o Câncer é o projeto mais bem trabalhado e preocupado com a informação. A informação é seu principal objetivo e trabalham com isso de forma muito clara e responsável. Na rede, existe uma família de personagens entre eles, crianças, adolescentes, pais, médicos e cachorros. Mostram também uma preocupação afetiva e de desenvolvimento infantil, que outros projetos não abordam. Por exemplo, há uma sessão no site que publica poesias e desenhos das crianças dos hospitais e uma outra sessão que disponibiliza cartões virtuais para os colegas da escola mandarem à criança em tratamento. 
4.2.3 Abrace - Associação Brasileira de Assistência às Famílias de Crianças

\section{Portadoras de Hemopatias}

Figura 4.7 Página inicial da Abrace

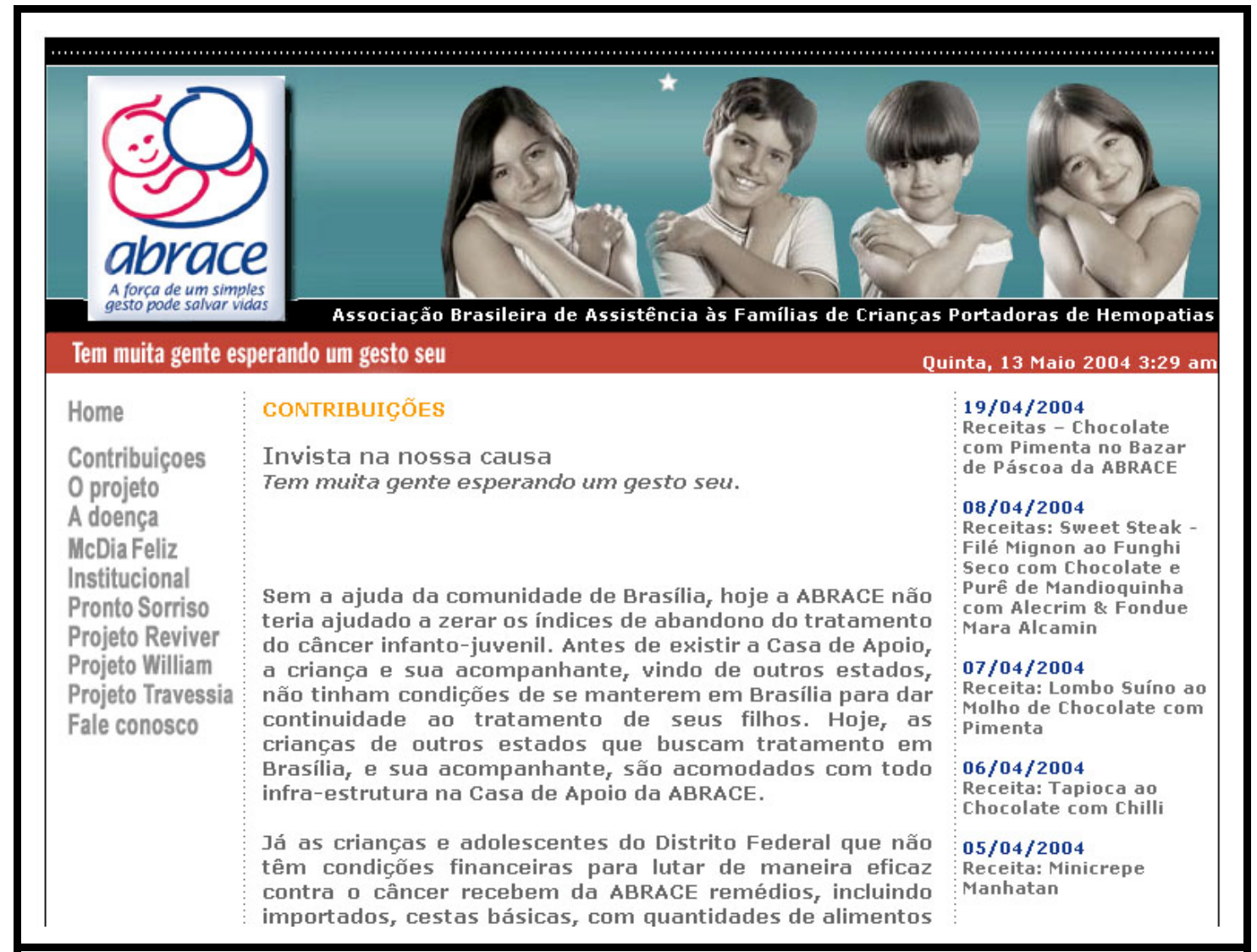

O projeto visual da Abrace é voltado a instituições, voluntários e doadores interessados na causa. Trata-se de um site institucional. Como não é voltado à criança, não há interesse direto em seu projeto gráfico. A marca da Abrace é simples e direta. Usa cores básicas e linhas e formas simples. Passa principalmente os sentimentos de amor e carinho de quem abraça a causa. 


\subsubsection{Hospital infantil europeu}

Figura 4.8 Capa e página da cartilha do hospital infantil europeu.

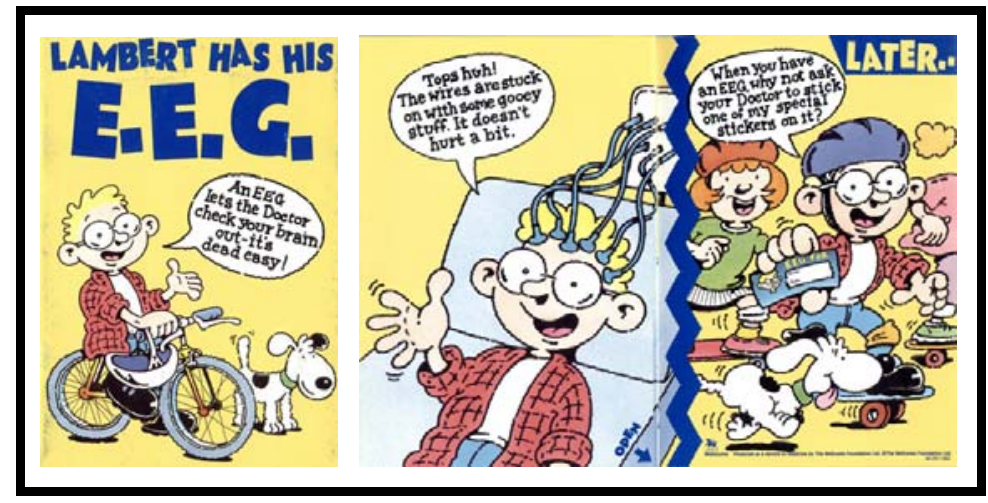

A cartilha é interessante por ser exclusivamente voltada à criança. Materiais como esse são difíceis de serem desenvolvidos, principalmente no Brasil. Com esse exemplo é possível observar o uso de cores, ilustrações grandes, chamativas, uso de balões, como estórias em quadrinhos e intervenções contrastantes.

\subsubsection{Instituto Ronald McDonald}

“O Instituto Ronald McDonald ${ }^{\mathrm{TM}}$ (IRM) foi fundado pelo McDonald's em 8 de abril de 1999 - Dia Mundial da Luta Contra o Câncer. Ele nasceu com o apoio de instituições dedicadas à luta contra o câncer infanto-juvenil, a partir da necessidade de se trabalhar no combate à doença durante o ano inteiro, e não somente durante o McDia Feliz ${ }^{\mathrm{TM}}$.” 
Figura 4.9 Página da internet do Instituto Ronald McDonald.

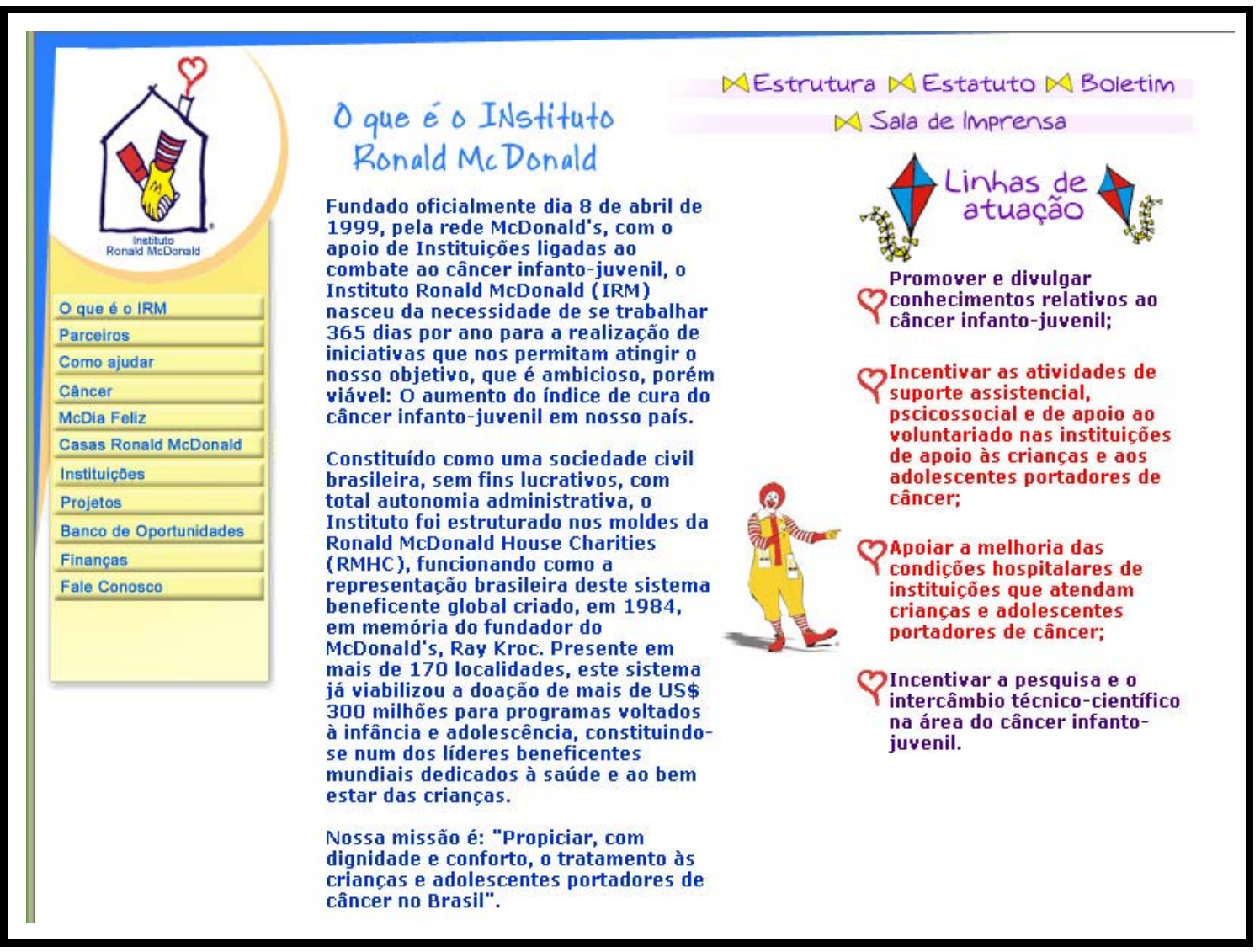

O site apresenta ilustrações e cores voltadas a crianças, apesar de também ser um site institucional, como a Abrace. Preocupa-se mais com os projetos, doações e finanças. Não é um site informativo sobre a doença, mas sim sobre os projetos, ajudas e maneiras de colaborar.

A seguir, na figura 4.10 há a marca do Instituto Ronald Mc Donald e do Mc Dia Feliz. O Mc Dia Feliz acontece um dia por ano, quando todo o dinheiro arrecadado da venda dos “BigMacs” é passado as instituições que tratam de crianças com câncer e precisam de dinheiro. 
Figura 4.10 Logo do Instituto Ronald McDonald e marca do McDia Feliz.

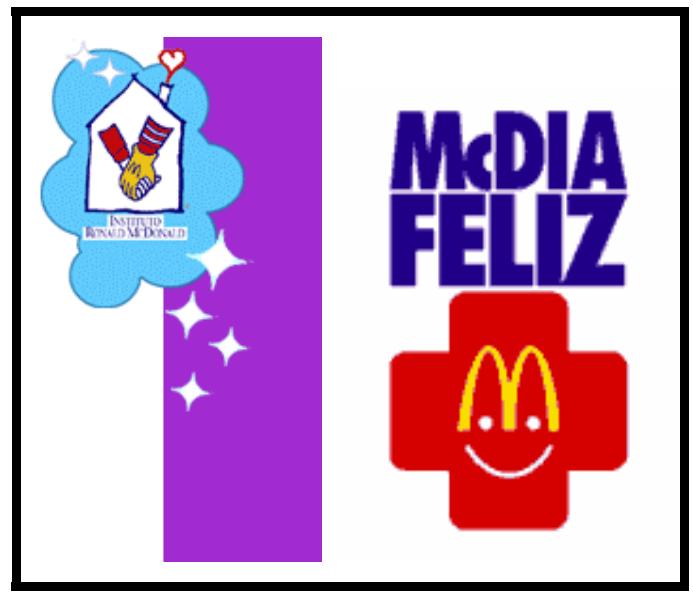

\subsection{Pesquisas com o público-alvo: crianças}

\subsubsection{Técnica de observação}

A técnica de observação significa aplicar os sentidos a fim de se obter uma determinada informação. Porém não podemos observar muitas coisas ao mesmo tempo. Por isso, é muito importante para a observação limitar e definir o que se deseja observar. (MORAES e MONT’ALVÃO, 2000, p. 39).

Dentro dos tipos de observação, utilizamos a observação sistemática, pois há objetivos a pesquisar e pretende-se, por meio da observação, registrar comportamentos e resposta específicas.

\subsubsection{Observação}

A observação foi realizada na brinquedoteca do Hospital de Apoio de Brasília, enquanto três a quatro crianças brincavam com a estagiária em psicologia, Isabela.

O tempo de duração da observação foi de aproximadamente 40 (quarenta) minutos. O objetivo geral dessa observação foi o de perceber o mundo recreativo da criança, como brincam e interagem com os brinquedos. Os objetivos mais específicos foram identificar:

- quais os jogos ou brincadeiras as crianças mais gostavam, por faixa etária;

- $\quad$ se existia o gosto pela leitura e quais leituras as atraiam, por faixa etária;

- $\quad$ se as crianças gostavam de histórias em quadrinhos e por quê; 
- com quais personagens as ciranças mais se identificavam e por quê;

- que, nos brinquedos, mais chamava a atenção das crianças (cores, formas, tema, estilo);

\subsubsection{Dados da observação}

O jogo de memória com que as crianças brincavam era de tema hospitalar. As ilustrações do jogo de memória traziam situações hospitalares com o objetivo de iniciar uma conversa com as crianças. As quatro crianças que brincavam tinham entre 4 a 8 anos. As crianças menores não entendiam perfeitamente a brincadeira e nem tinham paciência para esperar sua vez, querendo mexer nas peças quando tivessem vontade, atrapalhando o jogo, do qual os maiores estavam gostando. Por conta disso, a estagiária separou algumas cartas e possibilitou a brincadeira com os mais novos enquanto os mais velhos jogavam o jogo de forma adequada. Enquanto as crianças brincavam de memória, a estagiária aproveitava para perguntar sobre cada situação escolhida pelas crianças. Dessa forma, sempre que uma criança virava as peças do jogo, a psicóloga iniciava uma conversa. Ela via a imagem da ambulância e perguntava o que era. Espontaneamente uma criança respondia que era uma ambulância e em seguida a estagiária perguntava para que ela servia. A criança respondeu: “a ambulância serve para salvar as pessoas”. A partir dessa resposta ela continuava a conversa perguntando se ela já havia sido salva, quem já havia sido salvo ou para onde a ambulância a levara. Alguns momentos permitiram uma conversa mais longa, em outros a brincadeira chamava mais atenção. É interessante observar como as crianças se envolvem com o assunto, a conversa e como cada um conta sua experiência dependendo de cada situação.

Outra conversa interessante ocorreu quando em uma das imagens havia uma criança tirando sangue. Uma das crianças logo contou a história a respeito de quando cinco pessoas tiveram que segurar seu amigo para os médicos conseguirem tirar sangue dele. Com isso a estagiária conversou sobre a importância de se tirar sangue, explicou que não se deve ter 
medo e assim por diante. No geral, as crianças estavam entusiasmadas com o jogo de memória e com as conversas. Elas ficavam muito excitadas quando percebiam onde estavam os pares das figuras, ansiosas pela sua vez. Quando isso acontecia a conversa não surtia muito efeito.

Observou-se uma grande oportunidade de aprendizado com o uso do jogo da memória. A forma como a estagiária conduziu a brincadeira e os assuntos abordados mostravam como a criança entende o que está acontecendo com ela, como é o hospital, como ela deve cuidar de sua higiene e sua alimentação. Os assuntos abordados e trabalhados pela estagiária, assim como algumas frases das crianças foram:

- $\quad$ Lavar as mãos (momentos importantes);

- Ir ao dentista, para tirar as "sujeirinhas do dente” e ainda, “não pode escovar o dente e beber a água que está na boca”;

- Estetoscópio, "é para pressão";

- Termômetro, e logo a criança disse que é para ver se está com febre;

- A ambulância, que "serve para salvar as pessoas”;

- Seringa, "para ver o sangue” e "meu amigo precisou de cinco pessoas para segurar ele";

- Remédio, “é para a gente ficar melhor”;

Ainda no jogo da memória, alguns aspectos interessantes foram observados. As ilustrações usadas eram simples e lembravam os desenhos de crianças. Algumas tinham o uso de personagens famosos, como o "Ursinho Pooh” ou o "Mickey”. Uma diferente maneira de brincar com o jogo da memória chamou a atenção. Uma criança de 5 anos, ao virar uma peça que mostrava a imagem de uma balança, durante a conversa da psicóloga, ela pegou outra peça, de uma pessoa e colocou-a em cima da peça da balança. Então falou: "É para isso, para o menino se pesar na balança”. 
Observando mais o jogo no geral, percebe-se uma agitação, inquietação, como se as crianças não quisessem ficar sentadas. Elas mostram-se muito ativas, fazem outras coisas enquanto estão jogando. Na mesma mesa da memória há também carrinho, caminhão, blocos de montar e, entre a vez de cada um, as crianças brincam com essas outras coisas. O interessante é observar que elas não perdem a atenção no jogo de memória. As crianças costumam virar as peças dispostas na mesa e pegar para elas. Não têm o costume de deixar no lugar para os outros virem e até fixarem a posição. Mas, em compensação, após as crianças que pegaram já virem as cartas, elas devolvem para o lugar correto e passam a vez.

Após o jogo de memória, foi ainda possível observar as crianças brincarem com blocos de montar. A estagiária sugeriu montar uma cidade e cada criança faria um prédio, algo que existisse em uma cidade. As crianças construíram um estabelecimento comercial (shopping), um hospital, uma escola, duas árvores, um carro, um ônibus e um prédio para morar. As crianças disputam muito os blocos de montar e ficam comentando um a criação do outro. Nesses blocos há uma predominância da cor vermelha e observou-se que as rodas, para construir carros, eram muito disputadas.

\subsubsection{Conclusão da observação}

Primeiramente, a conclusão mais importante é a ratificação da importância do brincar no hospital e como a criança pode aprender enquanto está brincando, de maneira lúdica. Além disso verificou-se que as informações assimiladas durante a brincadeira podem realmente ajudar no tratamento da criança. A brincadeira se torna uma "desculpa” para iniciar uma conversa e trabalhar diversos assuntos importantes.

Conclui-se, claramente, que a criança tem facilidade em prestar atenção em muitas brincadeiras ao mesmo tempo. A brincadeira ou o jogo ideal para a brinquedoteca deve permitir a saída e entrada de crianças, sem prejudicar o jogo, já que elas podem se interessar 
mais por outra brincadeira ou podem ser chamadas para ir ao dentista ou para alguma consulta.

Acredita-se que como, normalmente, todas as crianças que estavam lá contavam alguma coisa da sua vida, as crianças se identificavam e percebiam que a situação pela qual estão passando é normal, ajudando no desenvolvimento social. Brincadeiras que permitam a construção e desconstrução pela criança, o transformar, o criar são aceitas e estimulam o interesse da criança.

Finalmente, observou-se que, para se conseguir alcançar plenamente os objetivos, deveria haver observações variadas e com mais tempo. Também se observou que, com a intervenção do observador, pode-se atingir mais facilmente outros objetivos, como saber quais cores as crianças mais gostam e quais são os seus personagens prediletos. Com essa intervenção, a técnica deixa de ser apenas observação e passa a ser também uma entrevista. Portanto, após a experiência da observação, percebeu-se que com uma entrevista com as estagiárias era possível obter maiores informações, já que essas estão há um ano ou mais em contato com as crianças do hospital, fazendo esse trabalho de recreação.

\subsubsection{Técnica de entrevista}

A entrevista é uma técnica por meio do qual o investigador se apresenta ao investigado e lhe formula perguntas, com o objetivo de obter dados que interessem à investigação. (...) A entrevista é o mais flexível de todos os métodos interrogativos de coleta dados. Daí podem-se identificar os mais diversos tipos de entrevista. A classificação se faz a partir de critérios diversos, sendo que o mais usual se refere ao grau de estruturação. As entrevistas menos estruturadas desenvolvem-se de forma mais espontânea, sem que estejam sujeitas a um modelo apriorístico de interrogação. Já as entrevistas mais estruturadas são aquelas que predeterminam em menor ou maior grau as respostas a serem obtidas. (MORAES e MONT’ALVÃO, 2000 p. 4344)

Entre vários tipos de entrevistas existentes, decidiu-se, para este projeto em questão, aplicar a entrevista focalizada ou centralizada, na qual, dentro de hipóteses e de certos temas, o entrevistados deixa o entrevistado descrever livremente sua experiência pessoal a respeito do assunto investigado. (MORAES e MONT’ALVÃO, 2000 p. 44) 


\subsubsection{Entrevistas}

O objetivo esperado com as entrevistas sintetizadas a seguir é o de identificar características importantes da recreação no hospital, dos brinquedos que mais atraem as crianças de acordo com a faixa etária e outras informações importantes sobre as brincadeiras nesse contexto hospitalar. Espera-se também compreender o que mais atrai a criança, referindo-se à percepção visual, como cores e formas, e saber se existe um hábito de leitura e de que personagens gostam.

A partir dessas informações, pretende-se identificar o nicho de atuação do jogo e saber o que esse nicho mais gosta, facilitando, assim, o processo de criação do jogo, um produto final do projeto. Além disso, espera-se que as informações coletadas nas entrevistas ajudem no desenvolvimento dos outros produtos finais.

\subsubsection{Entrevista com estagiária em psicologia do Hospital de Apoio: Catarina}

Catarina é estagiária há 1 ano e participa da recreação com as crianças, tanto na brinquedoteca como nas enfermarias, e busca, a partir disso, o entendimento das mudanças psicológicas que se dão na criança e na família depois da ocorrência da doença.

A entrevista durou uma hora e meia e foi abordado o seguinte assunto: Jogos e Brincadeiras de que as crianças mais gostam, dividos pelas faixas etárias de 2 a 4 anos, 5 aos 7 anos, 7 a 9 anos e 9 a 12 anos. Segundo Catarina, essa divisão deu-se devido às características observadas nesses grupos de crianças dessa idade.

Crianças de 2 a 4 anos

Os jogos e brincadeiras dessa faixa etária têm predominante a aparência visual com o predomínio de “estilos fortes”. Catarina explica o que seja esses “estilos fortes”: cores básicas e fortes, vibrantes, que chamam a atenção. Esses brinquedos e jogos também apresentam “estilos fortes” no movimento, no esconder e descobrir, no barulho, no som e no pintar e 
desenhar. São brincadeiras de desenvolvimento psicomotor, menos informativas. Uma característica importante que Catarina sugeriu é que, sempre que possível, principalmente nessa idade, o jogo deve envolver o pai e a mãe na brincadeira da criança.

\section{Crianças de 5 a 7 anos}

Essa faixa etária foi a mais difícil de Catarina conseguir definir as características específicas de jogos e brincadeiras. Segundo ela, as crianças a partir dos cinco anos começam a entender mais o que está acontecendo, mas têm uma dificuldade em aceitar a nova realidade no hospital, com a doença. É nessa idade que as crianças expressam espontaneamente os acontecimentos e situações da sua vida, mas sem julgamento, sem preocupações. As crianças comentam que foram tirar sangue, mas sem esperar nada, sem pensar em conseqüências ou sem objetivo de começar uma conversa. Nessa faixa etária também há um problema muito visível, o da criança não ter limite, o que acentuado com as crianças doentes no hospital, pelo fato dos pais sentirem pena do sofrimento da criança e quererem sempre satisfazer as vontades de seus filhos.

Crianças de 7 a 9 anos

De acordo com Catarina, essa é a fase que as crianças passam a compreender tudo o que acontece nessa nova realidade e, por isso, passam a ter um sentimento de culpa por não poderem ajudar os pais nos afazeres domésticos ou por não poderem acompanhar a escola, por exemplo. Com isso, às vezes se fecham, se julgam e colocam muito peso sobre suas responsabilidades. Eles falam mais sobre o que os preocupa, já pensando na conseqüência dessa fala. Nessa faixa etária, já se tem a compreensão pela leitura, já se entende jogos com regras e o ganhar e ou perder já é um objetivo. É interessante que um jogo mostre uma situação, um todo. Em relação às cores, é interessante que se tenha uma harmonia, e não como 
em fases anteriores, nas quais o importante eram cores fortes e vibrantes para se chamar a atenção. Os jogos que as crianças mais gostam são dominó, perfil e o jogo da vida.

Crianças de 9 a 12 anos

Crianças nessa faixa etária são pré-adolescentes que buscam identidade e uma diferenciação das crianças por não quererem mais ser vistas como criança e, por isso, se encontram em momento mais fechado, mais delas. Mas, quando a estagiária consegue adquirir sua confiança, tornam-se grandes amigos e companheiros de conversa. Por não participarem de todas as brincadeiras, elas reclamam que não há o que fazer no hospital. Mas quando brincam, gostam de jogar jogos mais adultos, como jogo da vida, xadrez e dominó.

Outras observações

Catarina destaca uma preocupação quanto ao entendimento da própria doença e a influência dos cuidados básicos com a alimentação e higiene no tratamento.

Destaca também algumas brincadeiras que fazem muito sucesso, com a participação da maioria das crianças, como:

- a fazendinha (vaquinha, cerquinha, curral), por ser bem próxima da realidade de muitos que são provenientes de zonas rurais;

- brincadeiras de inventar, como criar máscaras e bijuterias com miçangas;

- a festa que o Pronto Sorriso, palhaços voluntários, faz nas enfermarias, brincando e falando alto tanto com pais como com crianças.

Um aspecto importante que deve ser observado nas brincadeiras dentro das enfermarias são as restrições hospitalares e físicas a que a criança está submetida quando internada. 
É importante também o trabalho de criação de um vínculo positivo entre psicólogos e crianças antes de internações e procedimentos invasivos, como tirar sangue, para uma posterior aceitação da criança em relação às intervenções psicológicas.

Após descobrir a doença, pais e crianças criam um vínculo muito forte, já que um dependerá do outro para “sobreviver” a essa nova realidade do hospital. Por isso é importante a criação de uma atividade, de um jogo que estimule positivamente a interação de pais e crianças. Os pais, principalmente nas enfermarias, não têm o que fazer, por isso, participar das brincadeiras da criança é uma forma de distração, aprendizado e fortalecimento desse vínculo.

Outro aspecto importante que Catarina apresenta é o fato de os pais se interessarem pela forma como as psicólogas explicam a doença e tratamento para as crianças. Como essa forma é lúdica e simples, como, por exemplo, contar uma história envolvendo personagens, usar termos do cotidiano e palavras como "bichinhos maus do sangue”, os pais passam a entender também melhor as informações. Esse fato também facilita no vínculo do pai com o filho, visto que os dois terão a mesma linguagem quando falarem da doença e do tratamento. Os médicos, no geral, costumam explicar com termos técnicos, o que faz o pai não entender claramente o que está acontecendo com seu filho.

\subsubsection{Entrevista com mestranda em psicologia e ex-estagiária do Hospital de} Apoio, que desenvolveu um projeto de recreação no hospital: Rejane

O primeiro comentário de Rejane, que ela julga ser muito importante, é o fato da capacidade de fantasiar da criança. Essa capacidade é muito positiva, mas pode ser negativa dependendo do caso. Ela explica que, como a criança com câncer, em tratamento com quimioterapia, fica um tempo mais suscetível a doenças, por estar com seu sistema imunológico enfraquecido, deve-se evitar contato com outras crianças, com pessoas vacinadas ou portadoras de alguma doença, e também com animais e sujeira, no geral. A criança, em sua fantasia, pode achar que, na verdade, ela pode passar o câncer para outras pessoas. Rejane 
conclui, então, que é importante deixar bem clara certas informações, como essa, a fim de evitar sentimentos de culpa e mal-entendidos.

\section{Brincadeiras que Rejane destaca:}

- jogos de montar, criar;

- colagem;

- jogos com relevo, coisas diferentes do costume;

- peças para juntar, encaixar tipo um quebra-cabeça tridimensional);

- desenhar.

\subsection{Requisitos do projeto}

\section{Ilustração}

- haver rápido entendimento da situação ilustrada;

- $\quad$ ter simplicidade na forma;

- ter cores e características que “conversem” com as características formais dos personagens;

- focalizar ou detalhar a situação da ilustração.

\section{Personagens}

- ter formas definidas e nítidas;

- $\quad$ ter simplicidade na forma;

- $\quad$ suas formas devem deixar claro sua personalidade;

- ter cores atraentes e harmoniosas.

\section{Painéis}

- ser visualmente limpos;

- comportar todas as informações de maneira organizada e clara;

- $\quad$ ter as sessões bem definidas e de fácil acesso; 
- apresentar leiaute que “converse” com as características formais dos personagens e das ilustrações;

Jogo

- $\quad$ ser cooperativo e dinâmico;

- promover a interação entre crianças, pais, e psicólogos;

- possibilitar a discussão de assuntos hospitalares;

- permitir a intervenção da criança de forma que ela mude, construa, desconstrua e crie a partir dele;

- ter os personagens inseridos na realidade assim como suas características formais;

\subsection{Geração de alternativas}

\subsubsection{Personagens}

Os personagens principais nesse projeto são a Saúde e o Cuidado. São os personagens da campanha “Amigos para sempre: A Saúde, O Cuidado e Você!”. O objetivo da criação desses personagens visa alcançar uma relação de proximidade e identidade desses com a criança de maneira que ela adquira os hábitos que os personagens apresentam em sua própria vida. Desta forma participam diretamente da eficácia da campanha.

Em um segundo momento, para alcançar o objetivo, definiram-se quais conceitos serão agregados aos personagens, para se conseguir apresentá-los graficamente. Abaixo seguem os conceitos agregados na Saúde e no Cuidado: 
Quadro 4.2- Conceitos dos personagens Saúde e Cuidado

\begin{tabular}{|c|c|c|}
\hline \multicolumn{2}{|c|}{ Saúde } & Cuidado \\
\hline & Criança do gênero feminino; & - Criança do gênero masculino; \\
\hline- & Mais velha que o Cuidado; & - $\quad$ Mais novo que a Saúde; \\
\hline- & Sempre limpa e arrumada; & - Amigo da Saúde; \\
\hline- & Alimenta-se bem e é saudável; & - Escuta os conselhos da Saúde; \\
\hline- & bom exemplo; & - $\quad$ Moleque, despojado, arteiro; \\
\hline & $\begin{array}{l}\text { Ensina bons hábitos ao Cuidado } \\
\text { quando necessário; }\end{array}$ & $\begin{array}{l}\text { - Exemplifica os maus hábitos; } \\
\text { - } \quad \text { Mais branco; }\end{array}$ \\
\hline & Mais morena; & \\
\hline
\end{tabular}

A escolha dos personagens com uma representação humana e não animal deu-se, principalmente, por causa da grande necessidade de representações de situações muito específicas do ser humano. Além disso, o modo de representação humana permite evocar valores “morais”: lealdade, justiça, bondade; valores muito importantes a se passar para uma criança em desenvolvimento social. Também, de acordo com a pesquisa realizada buscando outros exemplos de personagens criados para crianças em hospitais, em situações como a desse projeto, observou-se apenas o uso de personagens humanos. Outro aspecto importante é o fato de personagens de representação animal serem mais apreciados por crianças menores, perdendo a relação mais próxima com crianças com mais de 7 ou 8 anos. De acordo com a literatura, a representação humana apresenta o inconveniente de limitar a capacidade de identificação pelo simples fato de ter de escolher um menino ou uma menina. Dessa forma, optou-se por dois personagens de ambos os sexos, de forma a minimizar esse inconveniente. 
Outras características também foram pensadas de modo a generalizar ao máximo as diferenças humanas. Além dos dois gêneros, há também as seguintes diferenças: idade, para conseguir atingir o público-alvo da campanha que são crianças de 6 a 12 anos e a cor (raça), para aumentar a possibilidade de identificação através da cor e evitar estereótipos raciais;

Após a definição dos conceitos é possível começar a imaginar o personagem. Sua personalidade já está formada e suas atitudes já são conhecidas. Lembrando que as formas do personagem são decodificadas pelas crianças intuitivamente, o personagem começa a ganhar os primeiros traços. Abaixo seguem as primeiras representações gráficas da Saúde e do Cuidado.

Figura 4.11 - Primeiras gerações de alternativas para a personagem Saúde.

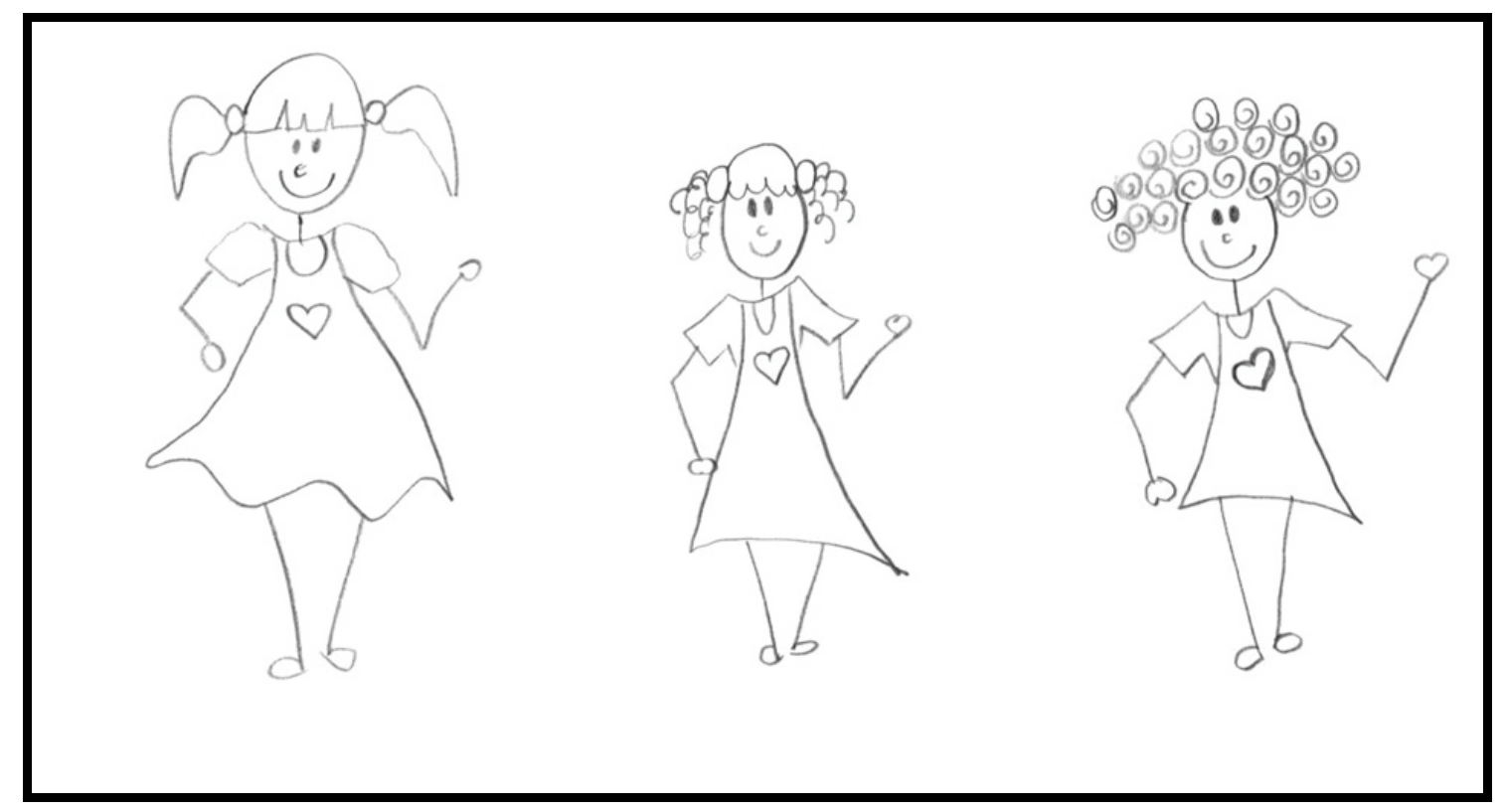


Figura 4.12 - Primeiras gerações de alternativas para o personagem Cuidado.

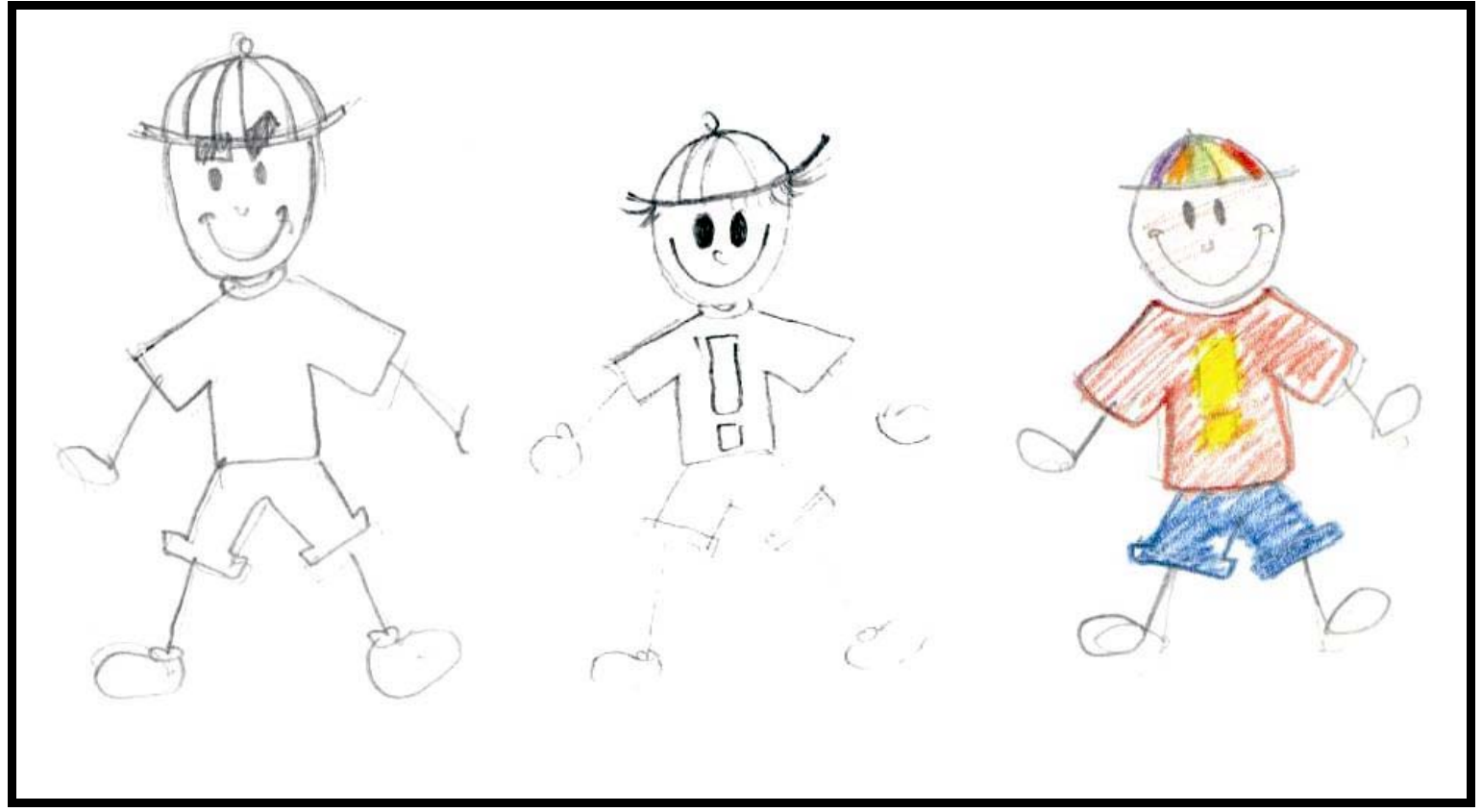

Figura 4.13 - Primeiras gerações de alternativas para os personagens Saúde e Cuidado.

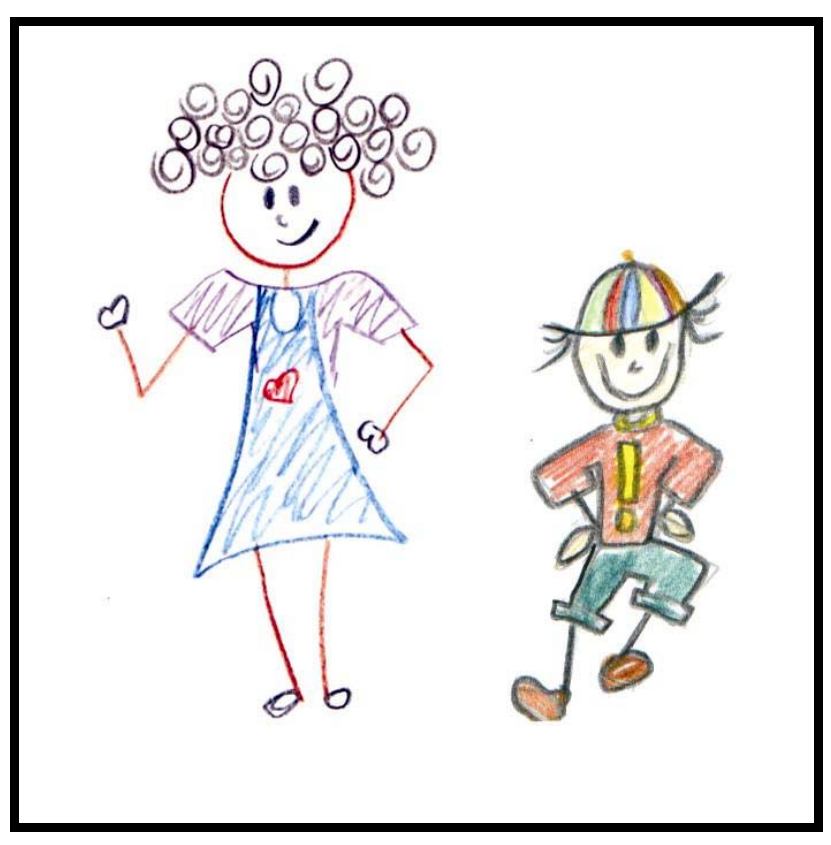

Nas gerações acima há a representação das diferentes características de cada personagem: o Cuidado mais novo que a Saúde e com cara de moleque; a Saúde com cabelo enrolado, diferente do Cuidado, de cabelo liso. Procurou ter formas simples para a maior assimilação dos personagens. Uma característica importante percebida nessa primeira fase é o uso de ícones: no Cuidado, o ponto de exclamação, na Saúde, o coração. Esses símbolos 
remetem à personalidade de cada um, representando suas características graficamente. O ponto de exclamação do personagem Cuidado é o símbolo usado em placas de sinalização que expressam “cuidado ou alerta”. Além disso, a sua forma e localização na blusa do Cuidado remete aos símbolos usados em personagens heróis, seja de quadrinhos ou desenho animado, facilitando a identificação. O coração da Saúde remete à emoção, ao envolvimento afetivo, mas principalmente a todo o processo de humanização tão visível nessa campanha de conscientização.

Figura 4.14 - Primeira alternativa vetorizada para os personagens Saúde e Cuidado.

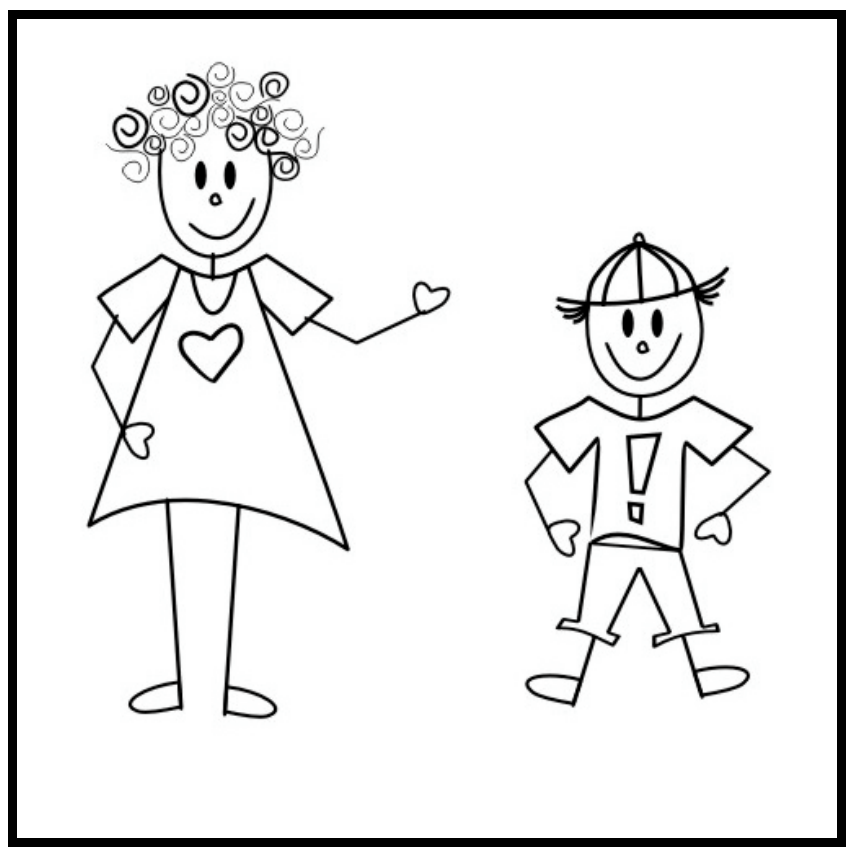

Analisando a primeira alternativa de acordo com a base teórica e técnicas de desenho, observam-se alguns problemas nas ilustrações dos personagens. A grande simplicidade nos traços perde características importantes de serem trabalhadas nas ilustrações das situações da campanha. Os membros como "pauzinhos” dificultam a aplicação em fundos diversos, assim como a visualização desses. As mãos e os pés, muito simplificados (sem os dedos), dificultam a identificação e não permitem algumas aplicações, como lavar as mãos ou cortar as unhas.

Assim, em uma segunda geração, essas simplicidades foram se detalhando sem perder o estilo e conceitos dos personagens, como pode ser visto adiante. 
Figura 4.15 - Segunda alternativa para os personagens Saúde e Cuidado (vista frontal e posterior).

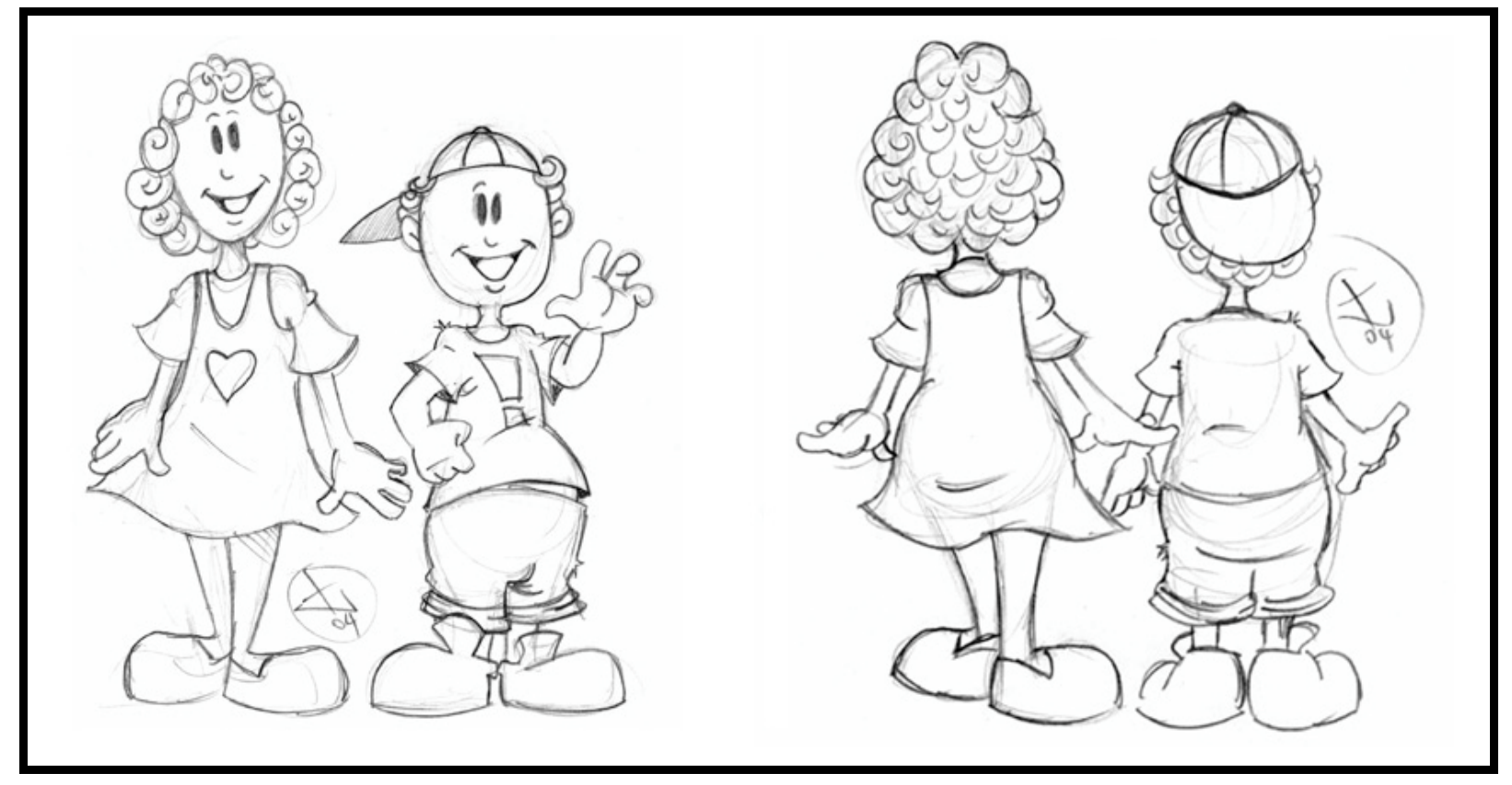

Observa-se claramente um maior detalhamento do desenho dos personagens. Suas características foram mantidas, mas o estilo se distanciou da proposta para esses personagens. O desenho mostra-se muito complexo (muitas linhas e detalhes) e alguns aspectos, como a barriga, o sapato e o cabelo do Cuidado, não o representavam de forma coerente com suas características. Inclusive, a idade dos personagens não ficou tão clara nessa alternativa.

Então, uma terceira alternativa começou a ganhar forma, tentando se posicionar entre a primeira (muito simples) e a segunda (muito complexa). Os traços e detalhes foram simplificados e procurou-se representar mais aproximadamente a idade dos personagens. O cabelo do Cuidado passou a ser liso, como pensado no início. A barriga do Cuidado foi retirada, pois havia muita associação com vermes e falta de higiene. O sapato estava muito certinho para o ar moleque que o Cuidado devia passar, então se pensou no uso de um chinelo, mais despojado. Partindo dessa resolução, também se optou pela camisa regata no lugar da de manga, o que fez o Cuidado ficar muito mais coerente com sua personalidade. A Saúde, que já parecia resolvida enquanto representação da sua personalidade, apenas foi 
simplificada acompanhando o estilo de desenho do Cuidado e preocupando-se com a diferença de idade dos dois.

Figura 4.16 - Terceira alternativa para os personagens Saúde e Cuidado.

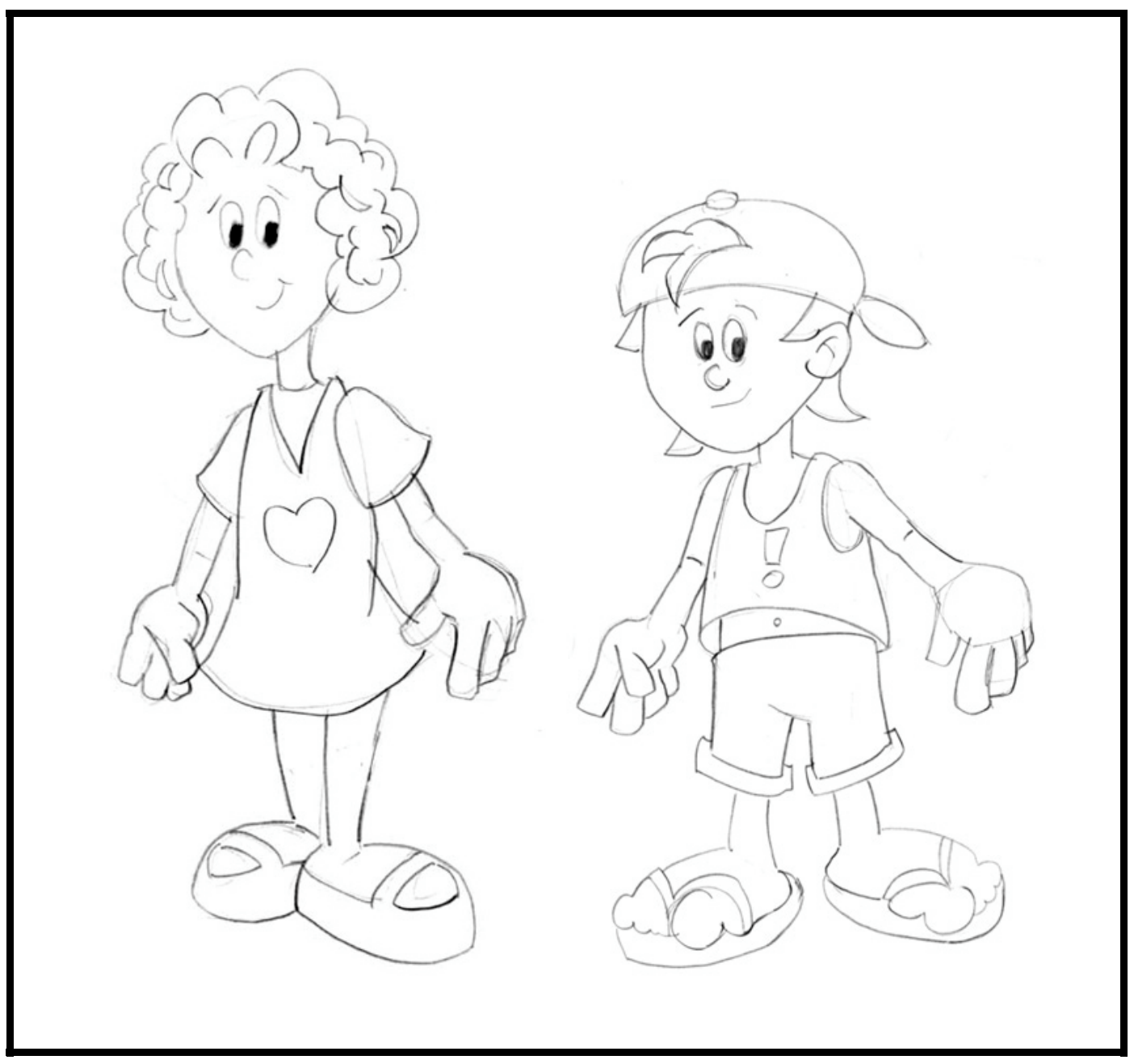

Com essa terceira alternativa foi possível observar as características de cada personagem, seu estilo e personalidade. As linhas, mais simples e em menor quantidade simplificam o desenho aproximando ao estilo de ilustração desejado. Voltando-se aos conceitos de cada personagem no quadro 4.4.1.2.1, observa-se que a ilustração condiz com cada personagem. 
Figura 4.17 - Vetorização da terceira alternativa para os personagens Saúde e Cuidado.

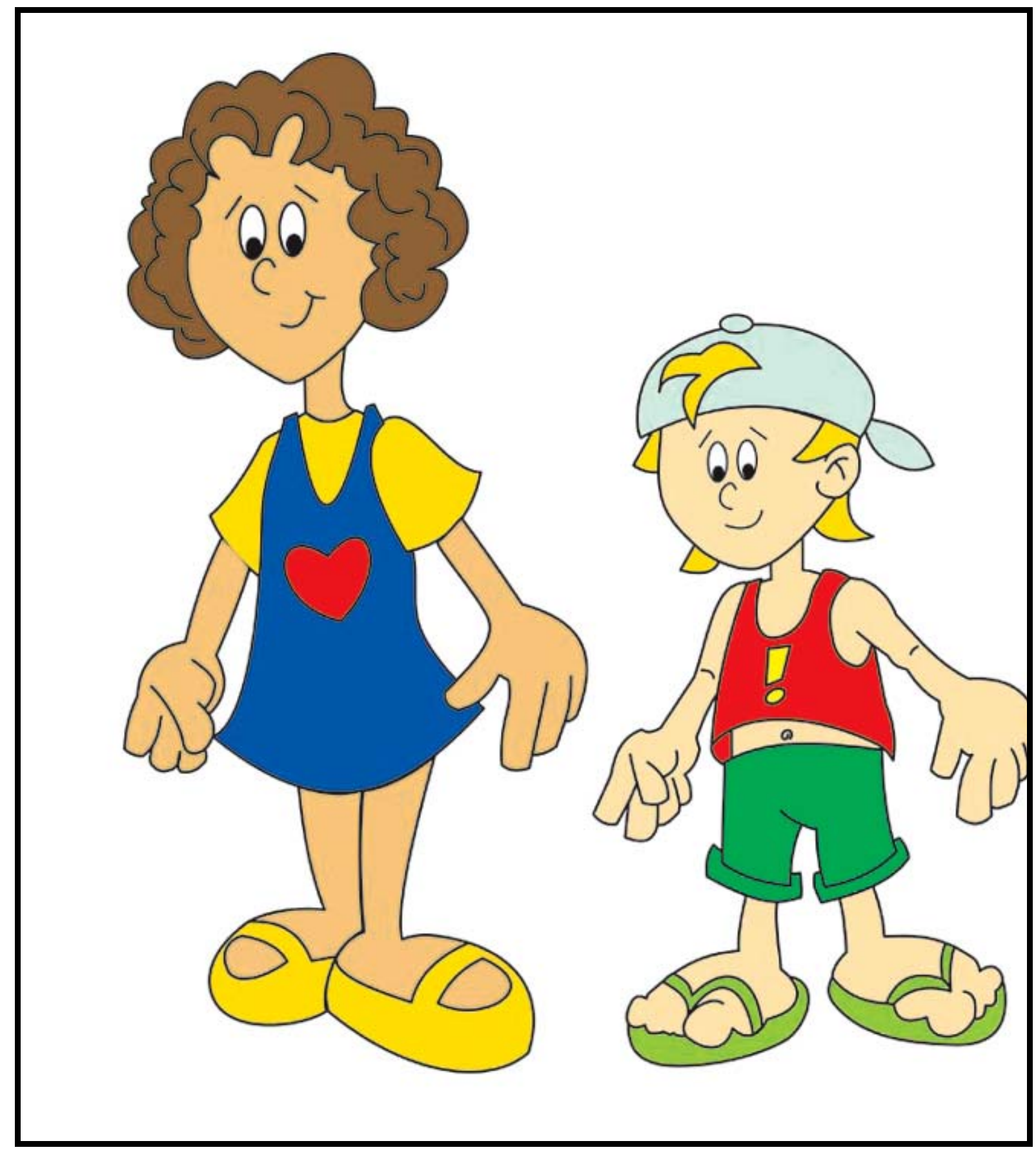

Na figura 4.4.7, os personagens já estão representados em vetor. A vetorização foi feita no programa CorelDraw versão 11. Tanto o desenho (traços) como o preenchimento (cores) foram realizados no mesmo programa.

As cores escolhidas para os personagens também significam sua personalidade e seus conceitos. A Saúde, que usa blusa e sapatos amarelos, passa alegria, espontaneidade e energia. 
Também transmite calor e conforto. Seu vestido azul, cor fria, contrasta com o amarelo e vermelho do coração, transmitindo paz, verdade, confiança e amizade. E o coração, vermelho, representa a humanização e a emoção do personagem. O Cuidado, de blusa vermelha com ponto de exclamação amarelo, faz a ligação direta com cuidado, perigo e atenção. Sua outra cor predominante, o verde, cor fria, acalma as outras cores quentes e também transmite saúde, coragem, esperança e tranqüilidade.

Com a forma e cor dos personagens definida, começa-se a pensar em técnicas de ilustração. Como melhor representar, reproduzir, colorir e apresentar esses personagens? Qual o melhor estilo de pintura (colorização) do desenho? Essas perguntas geraram uma nova fase na geração dos personagens, agora uma fase de colorização e definição do estilo das ilustrações.

\subsubsection{Colorização}

Com a intenção de maior aproximação e identificação com o público infantil, testes de colorização como as crianças têm o costume de fazer em seus desenhos foram aplicados nos personagens. Técnicas de pintura com o efeito do lápis de cor, caneta hidrocor e giz de cera foram testadas e avaliadas como visto em seguida.

Figura 4.18 - Personagens com efeito de lápis de cor.

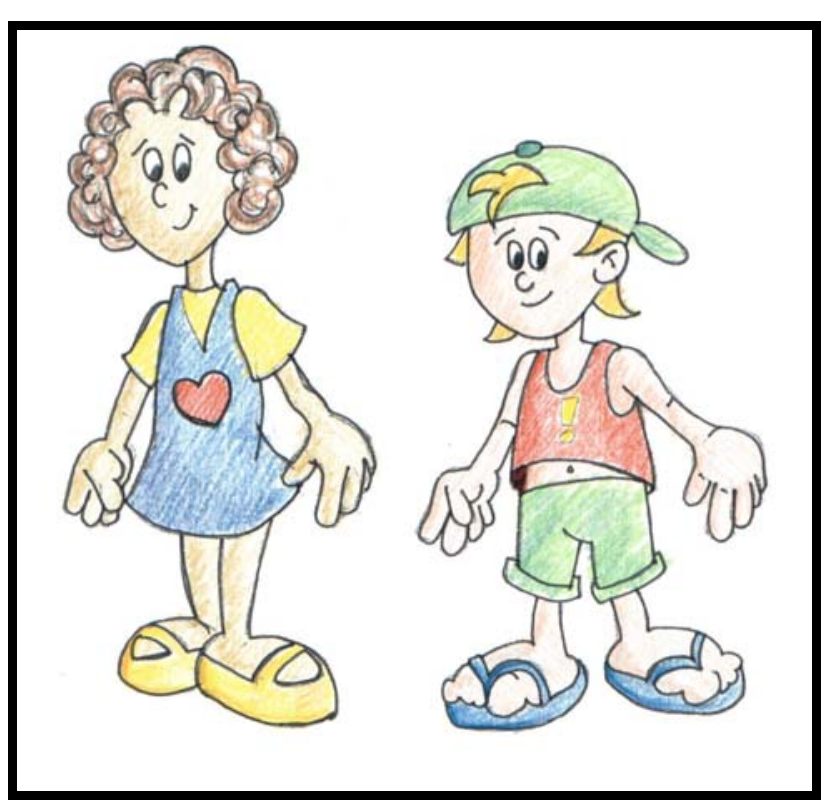


Figura 4.19 - Personagens com efeito de caneta hidrocor (contorno).

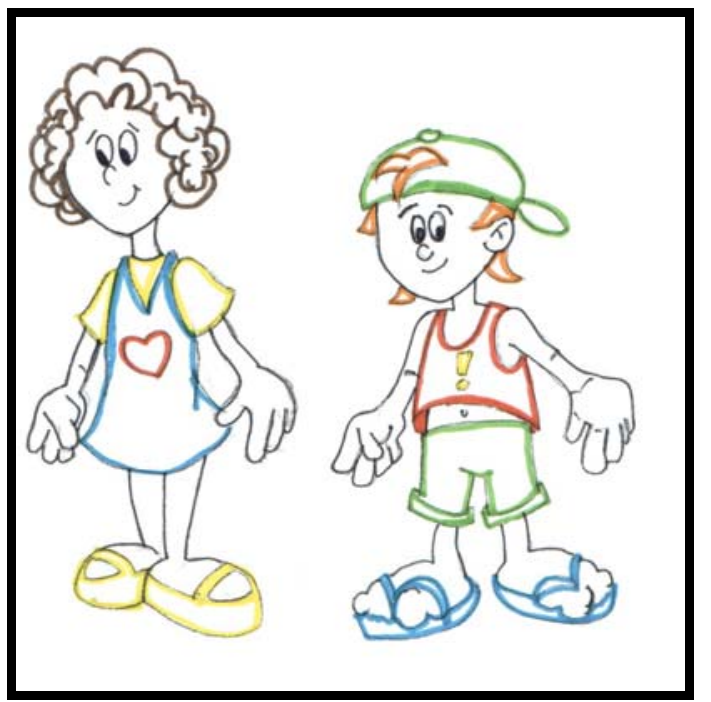

Figura 4.19 - Personagens com efeito de caneta hidrocor (preenchimento).

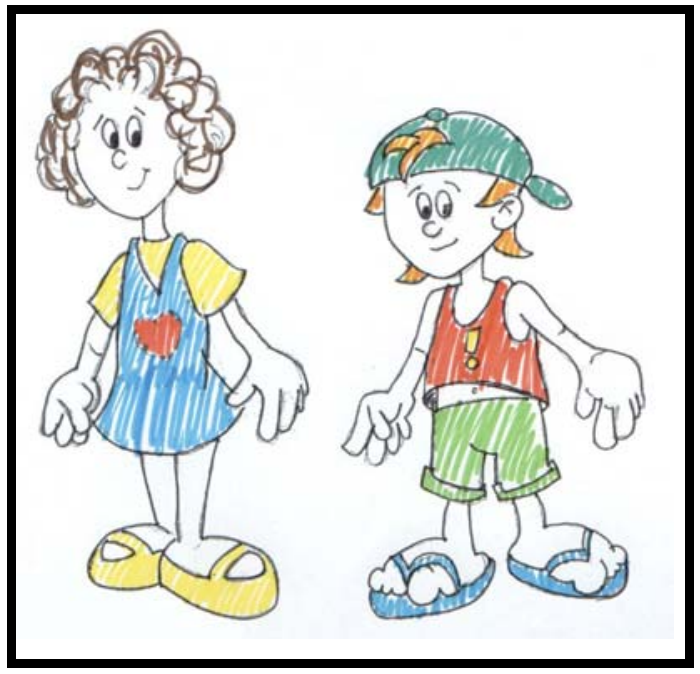

Figura 4.20 - Cuidado com efeito de giz de cera.

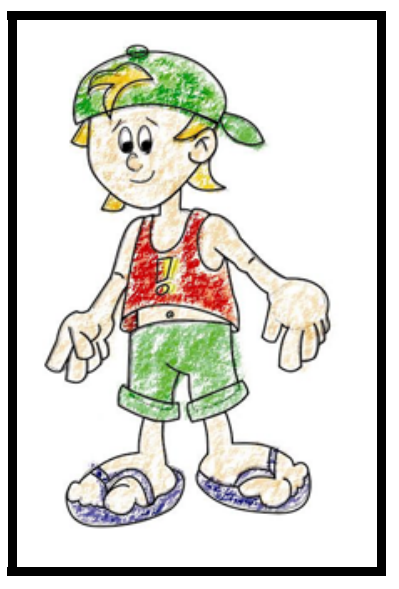

Os testes foram feitos colorindo os personagens à mão ou com o auxílio do Photoshop, versão 7.0, e os pincéis que imitam os efeitos das pinturas infantis. Na figura 4.4.1.3.1, os 
personagens foram coloridos à mão, com lápis de cor. Entre as alternativas apresentadas, esta foi a que mais combinou com os personagens. Usaram-se efeitos de sombra e o que se apresenta mais organizado. Nos outros testes de colorização imitando efeitos de desenhos de crianças, observa-se uma finalização não resolvida.

Com base na colorização com lápis de cor, alguns testes realizados no Photoshop podem ser vistos a seguir.

Figura 4.21 - Saúde e alguns testes de colorização no Photoshop.

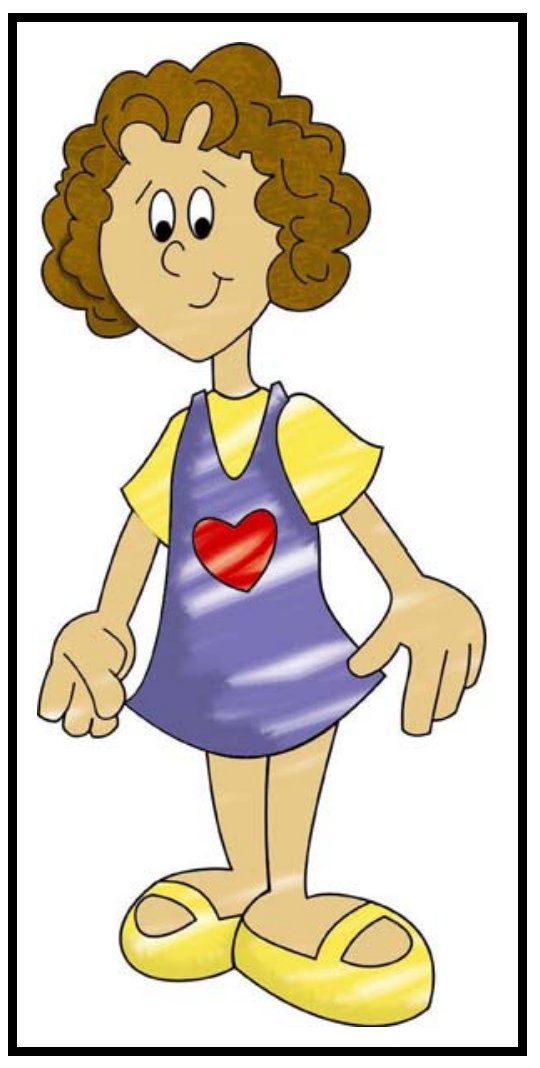

Essa colorização deu um efeito interessante, mas esse pincel, que deixa manchas brancas, a Saúde aparenta um aspecto sujo, desorganizado. Observa-se também o uso de textura no cabelo, o que apresentou um resultado bom, evidenciando os cachos da Saúde, a cor do cabelo e dando mais vida ao desenho, diferente de uma cor chapada ou lisa. 
Figura 4.22 - Saúde e Cuidado no teste final de colorização no Photoshop.

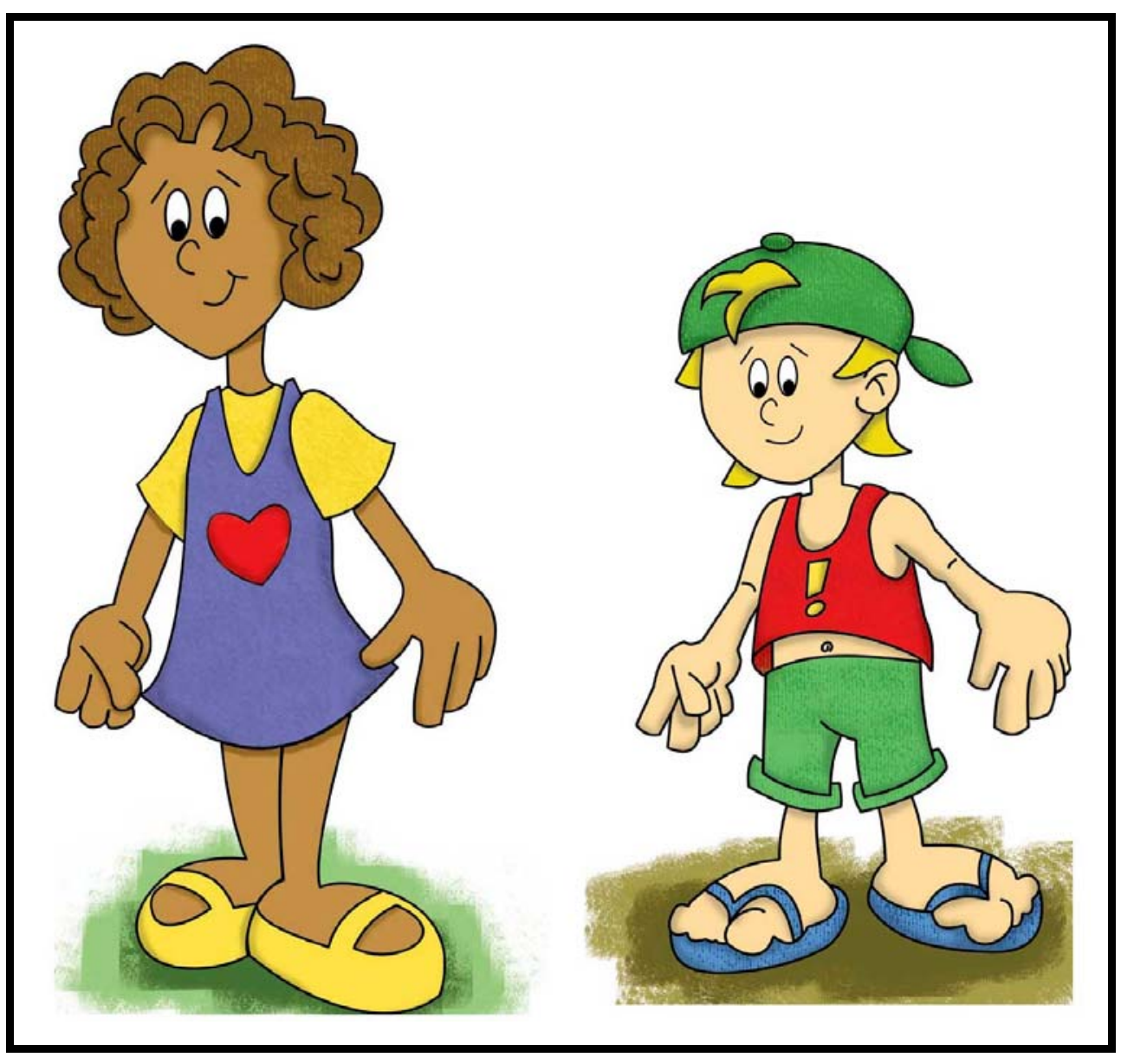

Nessa última alternativa de colorização procurou juntar as características importantes observadas de cada estilo de colorir. Nessa, a sombra é muito presente nos personagens. A textura também é visível e proporciona vida nas ilustrações. O uso de manchas, com um pincel, no fundo, cria um espaço onde os personagens se encontram representados de maneira livre. Com base nesses testes, para garantir a identidade visual, essas características de colorização serão incorporadas também nas ilustrações do projeto. 


\subsubsection{Ilustrações}

As ilustrações são fundamentais para a finalização dos painéis. Elas representarão graficamente as situações das informações sobre saúde abordadas na campanha.

As ilustrações partiram, em um primeiro momento, de vetorizações de fotografias. As fotos das situações exatas foram tiradas, no ângulo e distância escolhidos, para melhor representar a ação. As fotos foram vetorizadas no programa de vetorização CorelDraw, simplificando ao máximo as linhas sem perder a essência da ação.

Figura 4.23 Foto da situação e vetorização.

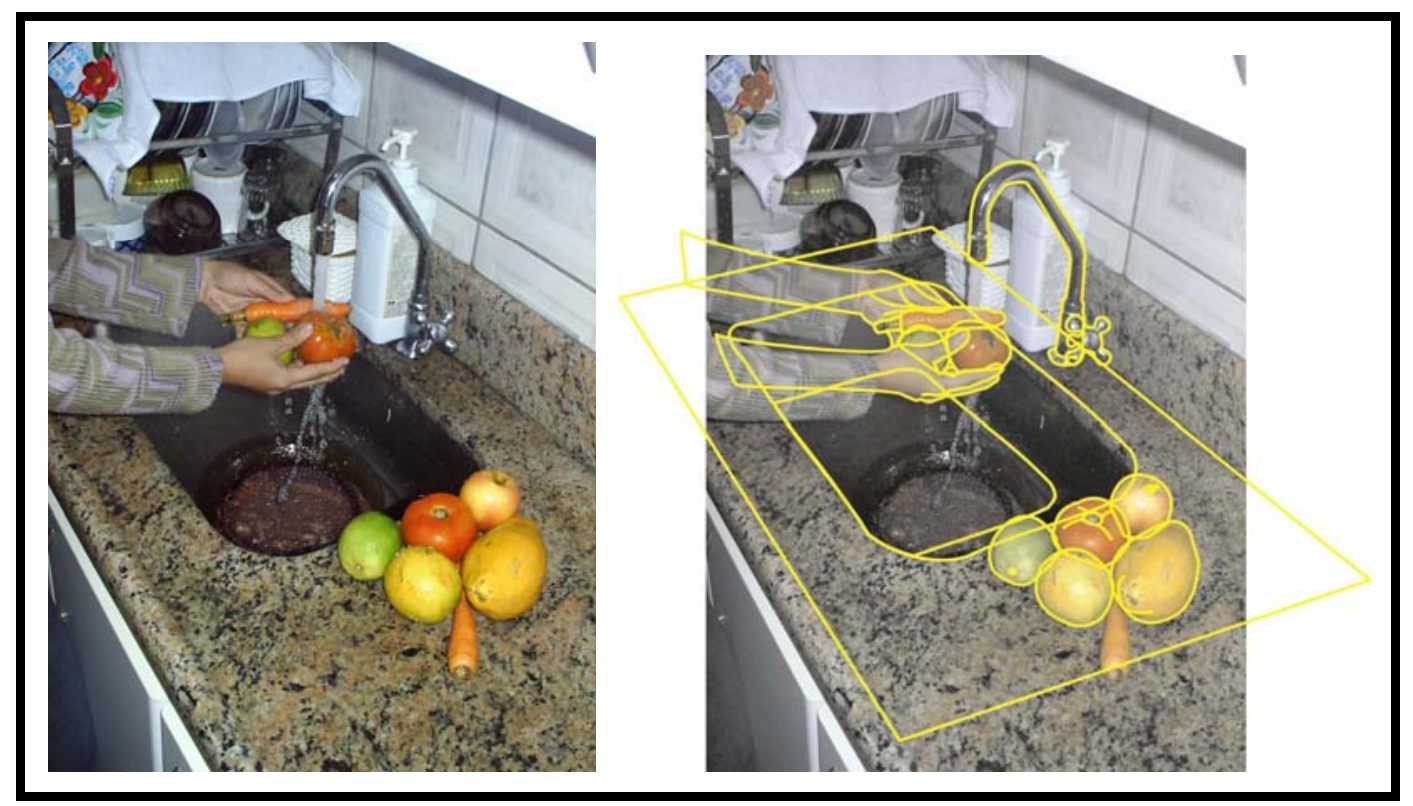

Figura 4.24 Resultado da ilustração vetorizada a partir da fotografia.

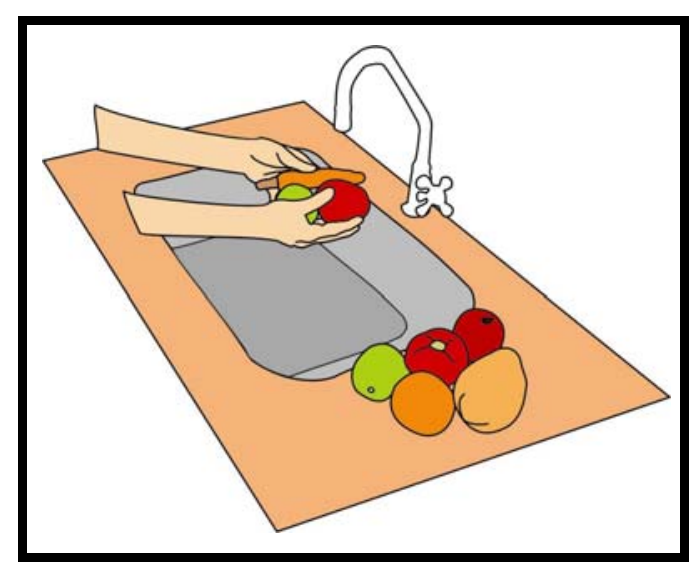


Após a vetorização, alguns problemas foram encontrados. O que mais incomoda visualmente na ilustração da figura 4. é o corte brusco nos braços. Como o objetivo da ilustração é o foco na situação, ação que deve ser informada, o corpo de quem está lavando os alimentos é uma informação secundária. A ilustração deve ser o mais direta e clara possível. Assim, buscaram-se alternativas para resolver esse problema.

Figura 4.25 Ilustrações vetorizadas mantendo as fotografias das situações.

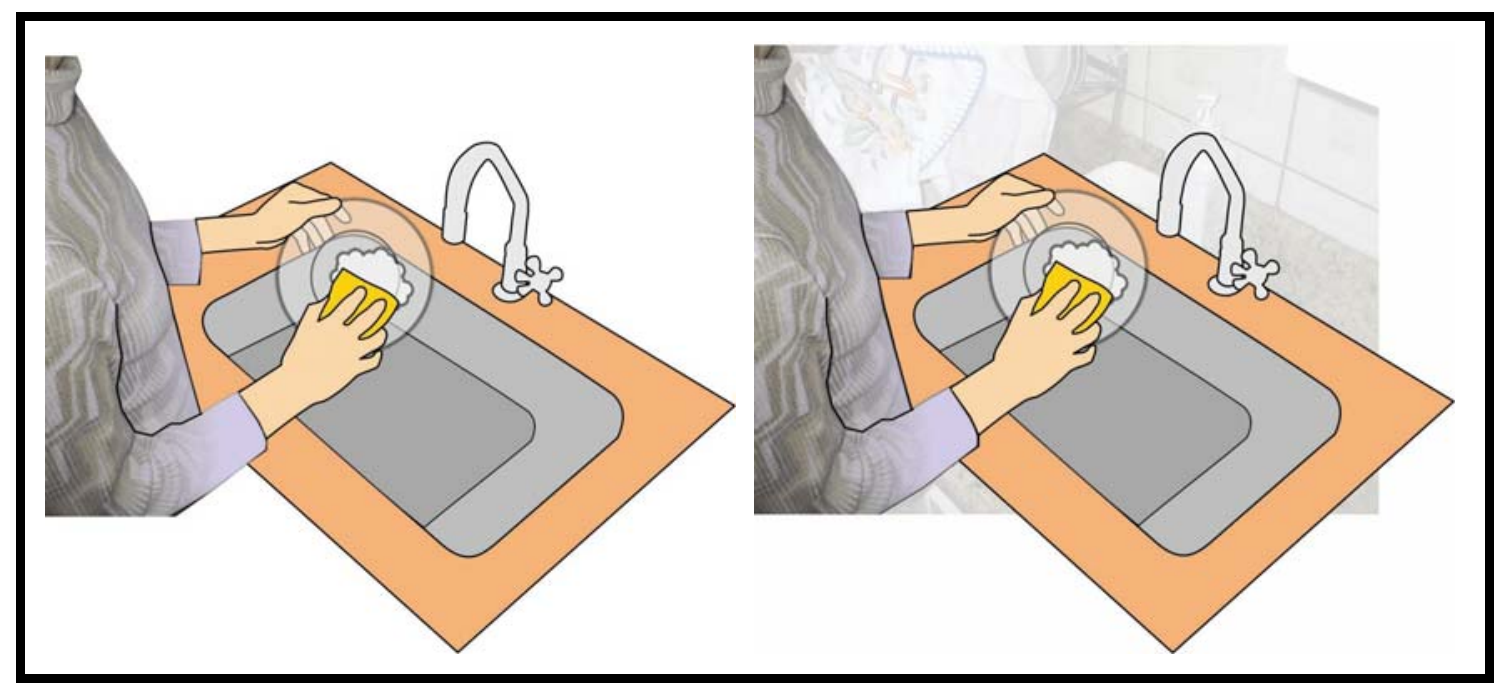

Com os resultados da figura 4. pode-se perceber que há uma melhora no corte dos braços, porém, além da ilustração ficar complexa visualmente, o problema anterior é resolvido em parte, visto que, agora, o incômodo passa a ser o corte brusco na cabeça. A figura 4. mostra como foi possível resolver a situação sem ter que colocar uma pessoa inteira e continuar a focar a ação.

Figura 4.26 Ilustração com os braços desaparecendo.

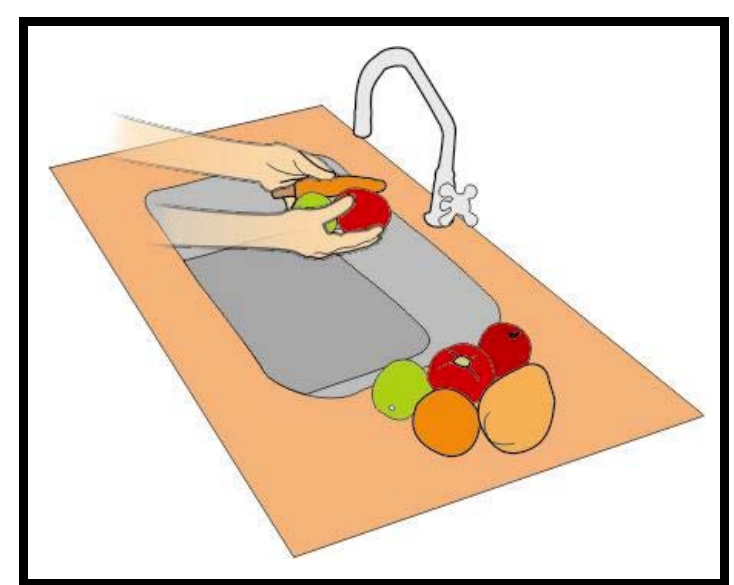


Com o primeiro problema solucionado, percebeu-se outro. O objetivo principal da ilustração nesse projeto é representar rápida e claramente a situação abordada. Sendo assim, o que há de mais claro nas ilustrações mostradas anteriormente é a pia. A pia está evidenciada, por conta do seu tamanho. Ela chama mais a atenção que a ação em si. Portanto, outra alternativa foi gerada.

Figura 4.27 Ilustração evidenciando a ação.

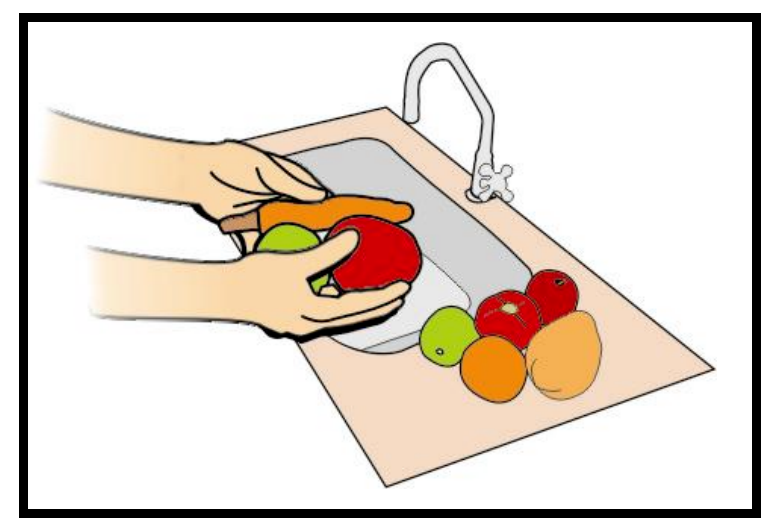

Outro aspecto importante diz respeito às cores. De maneira geral, as cores devem ter relação com a realidade, para o entendimento ser claro. Além dessa consideração, o uso de cores pastéis tem prioridade devido à ligação que as ilustrações devem ter com o universo infantil e com a identidade visual dos personagens Saúde e Cuidado.

\subsubsection{Painéis}

\subsubsection{Objetivos e restrições}

O objetivo principal dos painéis é dar suporte às ilustrações e às informações textuais que auxiliarão as explanações dos profissionais de saúde. A partir da análise da tarefa e do ambiente no qual são feitas as explanações, verificou-se que os painéis devem:

- ter custo baixo, devido à geral falta de recursos da Rede Pública; 
- $\quad$ ser leves e fáceis de segurar, já que na grande maioria das vezes eles serão utilizados e segurados pela própria pessoa que está explanando para o grupo informativo;

- ser de fácil manuseio, para facilitar a dinâmica durante a explanação, ou seja, podendo ser tanto passado de mão em mão quando mostrado frente e verso durante a explanação;

- ter fáceis transporte, devido à necessidade de locomoção do material do Hospital de Apoio ao Hospital de Base e vice-versa;

- ser fáceis de limpar, pois no ambiente hospitalar os objetos precisam ser limpos com uma freqüência bastante alta;

- $\quad$ ser duráveis, devido à redução de custos com a manutenção do material e a uma maior resistência durante o constante transporte;

- ser de simples reprodução, devido à necessidade de reprodução tanto para manutenção do material existente e disseminação desse material em outros hospitais e até em outros estados;

- ter a linguagem e ilustrações adequadas ao público-alvo;

- dispor as informações de maneira clara e de boa visualização a pelo menos 2 metros de distância.

\subsubsection{Resumidos e detalhados}

Existem duas situações nas quais os painéis serão utilizados. A primeira situação é durante um esclarecimento de dúvidas no decorrer de um grupo informativo, na qual uma diversidade de temas podem ser abordados. Isso significa que não existe muito tempo para se alongar na explicação de algum tema específico, mas, sim, para falar apenas sobre os assuntos mais importantes de cada tema.

Na segunda situação, que pode acontecer nas enfermarias ou em um consultório, por exemplo, os profissionais de saúde podem abordar assuntos mais específicos e mais 
detalhadamente, pois a quantidade de pessoas com dúvidas é menor e tem-se mais tempo para explicações, já que ninguém ali está esperando ser chamado para consultas, como acontece nos grupos informativos.

Dessa forma, como, para cada uma dessas situações, o tempo disponível para explicações, a quantidade e os tipos de dúvidas são diferentes, teve-se que dividir os painéis, e conseqüentemente suas informações, em dois grupos: resumidos e detalhados. Os painéis resumidos serão utilizados na primeira situação descrita, na qual se tem menos tempo para explicações porém muitas dúvidas sobre diferentes assuntos a serem sanadas. Já os painéis detalhados serão utilizados na segunda situação descrita, na qual se tem um ambiente mais reservado, com mais tempo para explicações mais detalhadas.

Após a definição de todas as informações a serem abordadas pelos painéis detalhados, as mais essenciais, que não podem deixar de ser mencionadas em nenhuma ocasião, serão selecionadas algumas para compor o grupo de painéis resumidos. Tanto a relação das informações que serão ilustradas nos painéis detalhados quanto a seleção das informações para os painéis resumidos serão feitas pelos profissionais de saúde responsáveis por seus respectivos temas. Os painéis resumidos e os detalhados serão divididos nos mesmos seis temas propostos para a organização das informações - estes temas estão relacionados na página 49 desta monografia.

\subsubsection{Formato}

Visto que as informações (ilustrações e textos) devem ser vistas a uma distância de mais ou menos 2 metros e que os painéis devem ser leves, fáceis de segurar e manusear, o melhor formato encontrado foi o A3 (420 x $297 \mathrm{~mm})$.

Além disso, o formato A3 proporciona uma reprodução simples, pois como o material será, em um primeiro momento, produzido em gráficas rápidas, o formato, para este tipo de 
empresa, é comum e, comparativamente com formatos maiores, o custo com empresas de plotagem seria bem mais alto e a reprodução mais trabalhosa.

\subsubsection{Material}

Parte Interna: papel branco de gramatura 120gr com impressão, em um primeiro momento, em impressora laser. A gramatura não precisa ser muito alta já que todo o material será plastificado. Dentro das gramaturas disponíveis, esta está na faixa de preço mais baixo e, mesmo assim, propicia uma impressão qualidade, sem que o papel “enrugue” e danifique a impressão.

Parte Externa: plastificação a quente, para conservação, limpeza e utilização dos dois lados do papel.

\subsubsection{Conteúdo}

Os painéis são compostos de:

- Cabeçalho;

- $\quad$ Ilustrações (o desenvolvimento das ilustrações se encontra no item 4.5.3);

- Frases explicativas das ilustrações;

- Personagens.

A seguir serão detalhadas as funções e caraterísticas de cada um desses conteúdos.

\subsection{Cabeçalho}

Os cabeçalhos se encontram na parte superior do painel. São diferenciados por cores de acordo com temas. Cada tema, como dito anteriormente, engloba um conjunto de informações. Existem seis temas e, portanto, seis cores. Os seis temas são: Higiene - azul; Limpeza - laranja; Cuidados Odontológicos - lilás; Alimentação - verde ; Doença Falciforme - vermelho; e Câncer - amarelo. Os cabeçalhos mantêm uma identidade, sendo preenchidos 
pela cor com menos matiz e contornados com a cor saturada. Além da identificação do tema por cor, o nome do tema também está presente do lado esquerdo. No cabeçalho, do lado direito, existe um símbolo para identificar se o painel pertence ao grupo dos painéis detalhados e painéis resumidos. Essa identificação deve ser clara e visível, para facilidade na escolha dos painéis e também discreta pois é uma informação importante apenas a quem está explanando sobre o assunto.

Figura 4.28 - Relação de cores e temas do cabeçalho do painel.

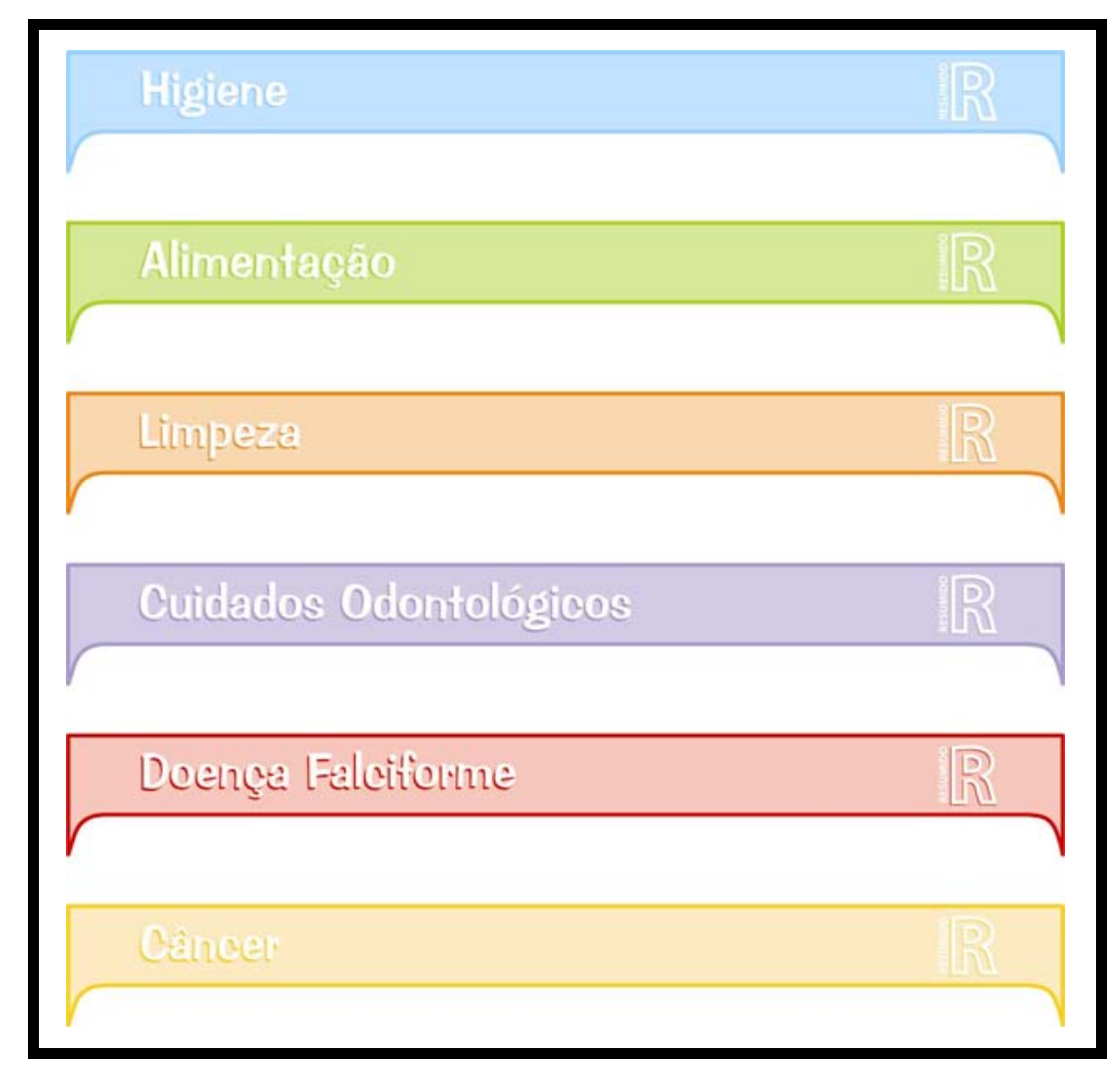

As cores das seções foram escolhidas com base na sensação e na relação visual com a idéia e com os elementos que podem compor um determinado tema, como, por exemplo, verde para alimentação, por lembrar vegetais que são componentes básicos de uma alimentação saudável; azul para higiene, por lembrar água, banho etc.

A tipografia escolhida para ser utilizada no tema deve apresentar as seguintes características:

- possibilitar leitura a 2m de distância; 
- ter um desenho que se identifique com as formas das ilustrações e dos personagens;

- ser mais descontraída para não perder a questão lúdica, já que, para as frases explicativas, a fonte escolhida foi mais “séria” por ter que privilegiar a leitura. (Em títulos pode-se usar uma fonte fantasia, por não se haver compromisso tão forte com a leitura e também por não ser a informação principal e primordial como são as informações das frases explicativas).

Inicialmente escolheram-se três fontes para o nome do tema, cada uma privilegiando um aspecto diferente.

Figura 4.29 - Fonte Carnation

\section{Carnation ABCDEFGHIJKLMNOPQRSTUVWXYZ abcdefghijklnnopqrsturwxyz 0123456789 áéíóų̧̃ãõ}

A fonte Carnation foi testada por ter o lado lúdico e infantil muito marcante nas suas formas, com curvas assimétricas e disposição irregular. Porém, não foi utilizada no painel por não concordar, da forma que se esperava, com o traço das ilustrações.

Figura 4.30 - Fonte Neo

\section{Neo}

ABCDEFGHIJKLMNOPQRSTUVWXYZ abcdefghijklmnopqrstuvwxyz 0123456789 áéíoúçãõ 
A fonte Neo foi testada por também reforçar o lado lúdico e infantil na escrita. Porém, não foi utilizada no painel por ter um corpo muito grosso e, a uma distância de 2 metros, as letras parecem “colar” umas nas outras, tornando a leitura difícil.

Figura 4.31 - Fonte Impress

\section{Impress B十 \\ ABCDEFGHIJKLMNOPQRSTUVWXYZ \\ abcdefghijklmnopqrstuvwxyz 0123456789 áéíúçããó}

A fonte Impress foi testada por lembrar uma escrita a mão e ter um desenho mais descontraído. Essa fonte foi a escolhida para compor o nome do tema, pois possibilita uma boa leitura a 2 metros de distância e seu desenho e formas estão mais de acordo com os desenhos e formas das ilustrações.

Em relação ao símbolo para identificação de painéis resumidos e detalhados, primeiramente pensou-se em utilizar um retângulo preenchido para representar o grupo de painéis detalhado, e um retângulo só com o contorno colorido da mesma cor do retângulo preenchido. Pode-se ver a idéia no exemplo abaixo: 
Figura 4.32 - Identificação dos painéis resumidos e detalhados 1

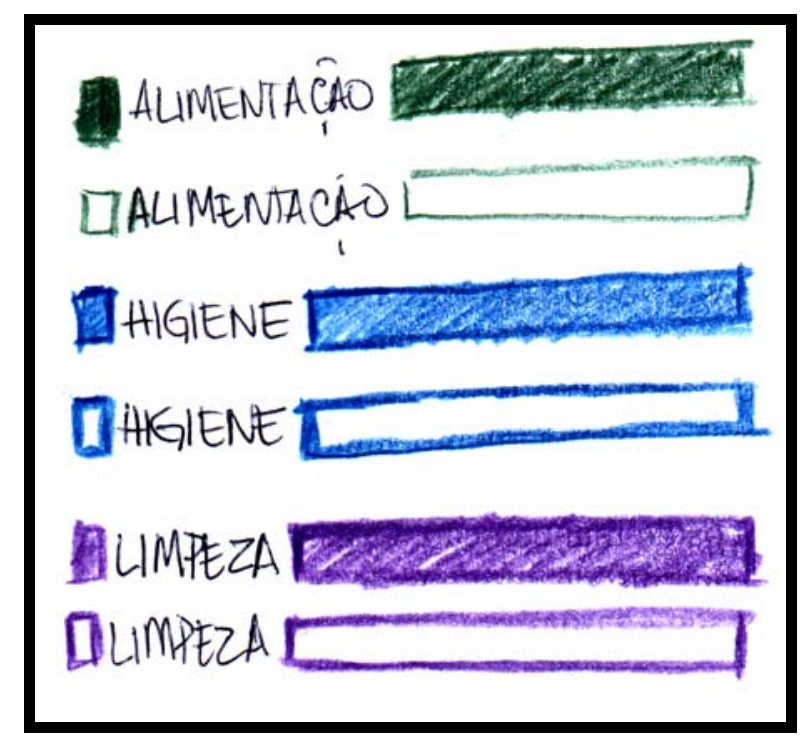

Porém, com o desenvolvimento do leiaute do painel, o uso do retângulo só com o contorno faz com que o visual do perde-se o seu efeito de fazer com que a área branca "salte" indo para o primeiro plano na visualização do painel. Por isso, optou-se por desenvolver outro esquema para identificação dos painéis detalhados e resumidos. Para essa nova forma de identificação, constatou-se que não há necessidade que essa informação esteja visível para todos e que ela deve ser clara e objetiva apenas para o profissional que está explanando sobre o assunto.

Figura 4.33 - Identificação dos painéis resumidos e detalhados 2

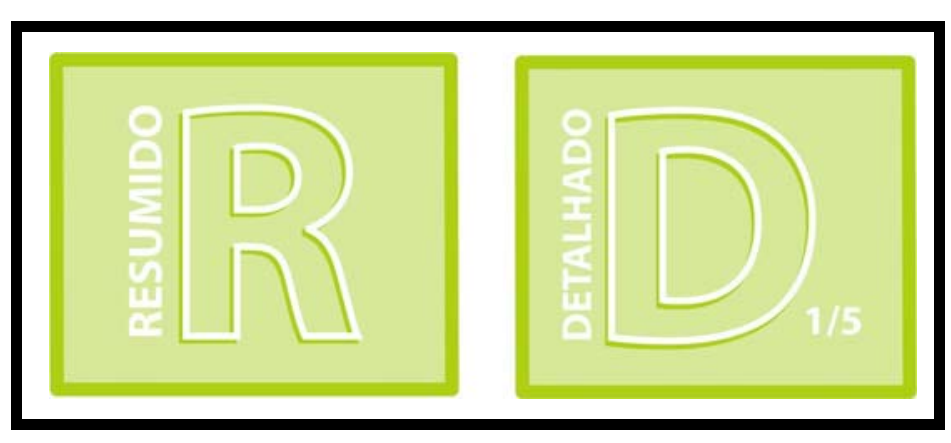

\subsection{Frases explicativas}

São sentenças curtas que acompanharão as ilustrações, explicando verbalmente a ação representada pela ilustração. Como são textos para serem lidos e compreendidos por crianças, principalmente, e pais a uns 2 metros de distância, levar-se-ão em conta, para a escolha da 
tipografia, as informações obtidas a partir da pesquisa bibliográfica sobre tipografia para a leitura da criança, tais como:

- Os caracteres devem ter simplicidade na forma;

- Os caracteres ascendentes mais altos enfatizam a forma da palavra;

- Os caracteres devem ser de fácil distinção. Alguns caracteres, como o “a” e o “o”, dependendo da fonte, são facilmente confundidos;

- Fontes com serifa ou sem serifa não apresentaram muita diferença nos resultados da pesquisa, porém $17 \%$ preferiram fontes sem serifa;

- Caracteres com algum traço mais infantil ou caracteres comuns também não apresentaram muita diferença, porém $13 \%$ das crianças preferiram fontes sem o traço infantil;

A partir disso definiu-se que a tipografia para esses textos será:

- fonte sem serifa

- formas e linhas do caracter sem rebuscamento, ou seja, sem grandes contrastes entre fino e grosso;

- diferenciação, principalmente da letra “o” e da letra “a” evidente.

Opções de fontes para o texto das frases explicativas

Figura 4.34 - Fonte FrankGothic

FrankGothic ITC Bk BT

ABCDEFGHIJKLMNOPQRSTUVWXYZ

abcdefghijklmnopqrstuvwxyz

0123456789 áéíóúçãõ 


\section{Frutiger Roman \\ ABCDEFGHIJKLMNOPQRSTUVWXYZ abcdefghijkImnopqrstuvwxyz 0123456789 áéíóuçã̃̃}

\section{Myriad Roman}

ABCDEFGHIJKLMNOPQRSTUVWXYZ abcdefghijklmnopqrstuvwxyz 0123456789 áéíóúçãõ

Apesar dos três exemplos das fontes acima se encaixarem nos requisitos definidos anteriormente para a escolha da tipografia, após os testes realizados com as fontes em conjunto com as ilustrações e personagens, verificou-se que a fonte que mais se adequou às formas, desenho e estilo do painel foi a fonte Myriad Roman.

\subsection{Personagens no painel}

Os personagens também aparecem nos painéis, em dois momentos distintos. Um momento é quando os personagens aparecem abaixo das ilustrações sorrindo ou tristes com o sinal de “ok” ou “jóia” ou ao contrário. Eles também acompanham um balão como os de estória em quadrinhos, com uma fala (frase explicativa), que reforça as informações das ilustrações. Os personagens assumem um papel como o de "avaliadores da situação”. Esses personagens têm como função falar ao público que se identificou com eles a fim de que as informações passadas sejam aceitas e assimiladas. 
Figura 4.37 - Personagens no painel 1

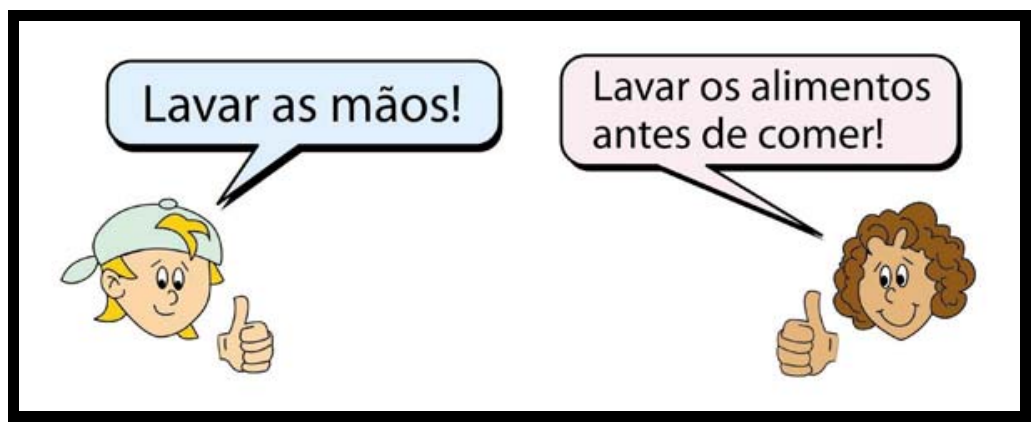

O outro momento é quando, em um dos lados dos painéis, existem apenas duas ilustrações. O personagem, Saúde ou Cuidado, preenche o lugar da terceira ilustração. Nessa situação, os personagens estão em uma posição como que se estivessem curiosos, entrando em algum lugar, querendo saber o que está acontecendo. Sua função é a de reforçar seus conceitos de saúde e cuidado e a de associar os painéis à campanha “Amigos para sempre: a Saúde, o Cuidado e Você!”.

Figura 4.38 - Personagens no painel 2

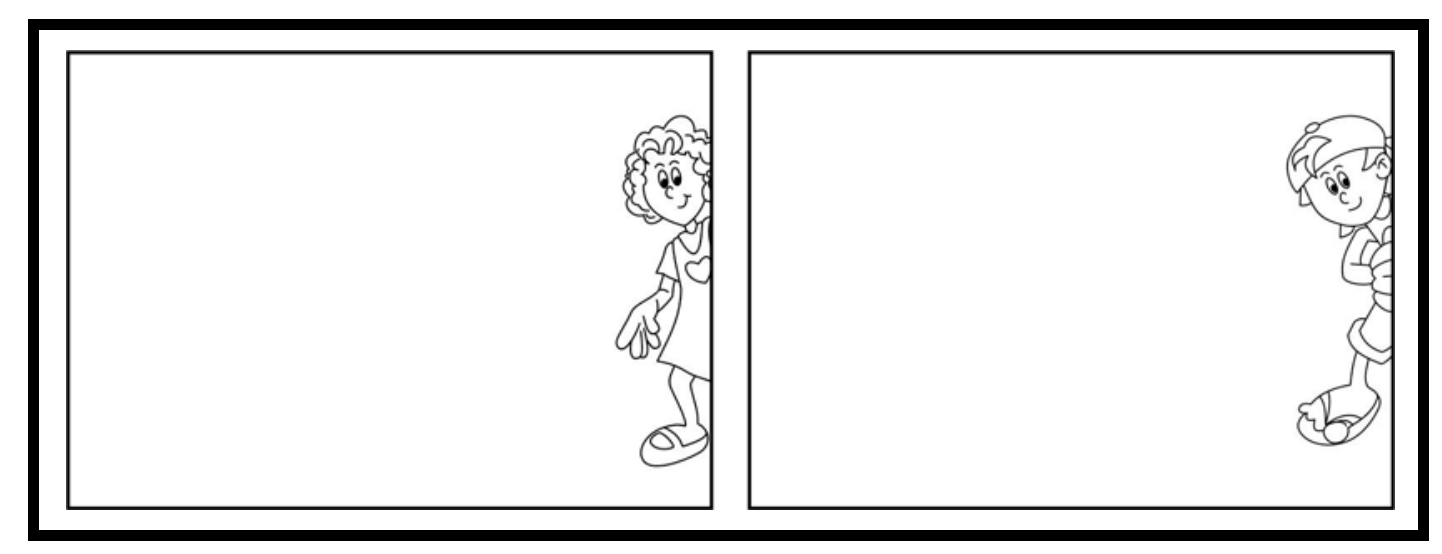

\subsubsection{Leiaute}

Para o leiaute dos painéis, primeiramente pensou-se qual seria a melhor orientação, se vertical ou horizontal, para disposição de todo o conteúdo planejado. 
Figura 4.39 - Testes horizontal e vertical

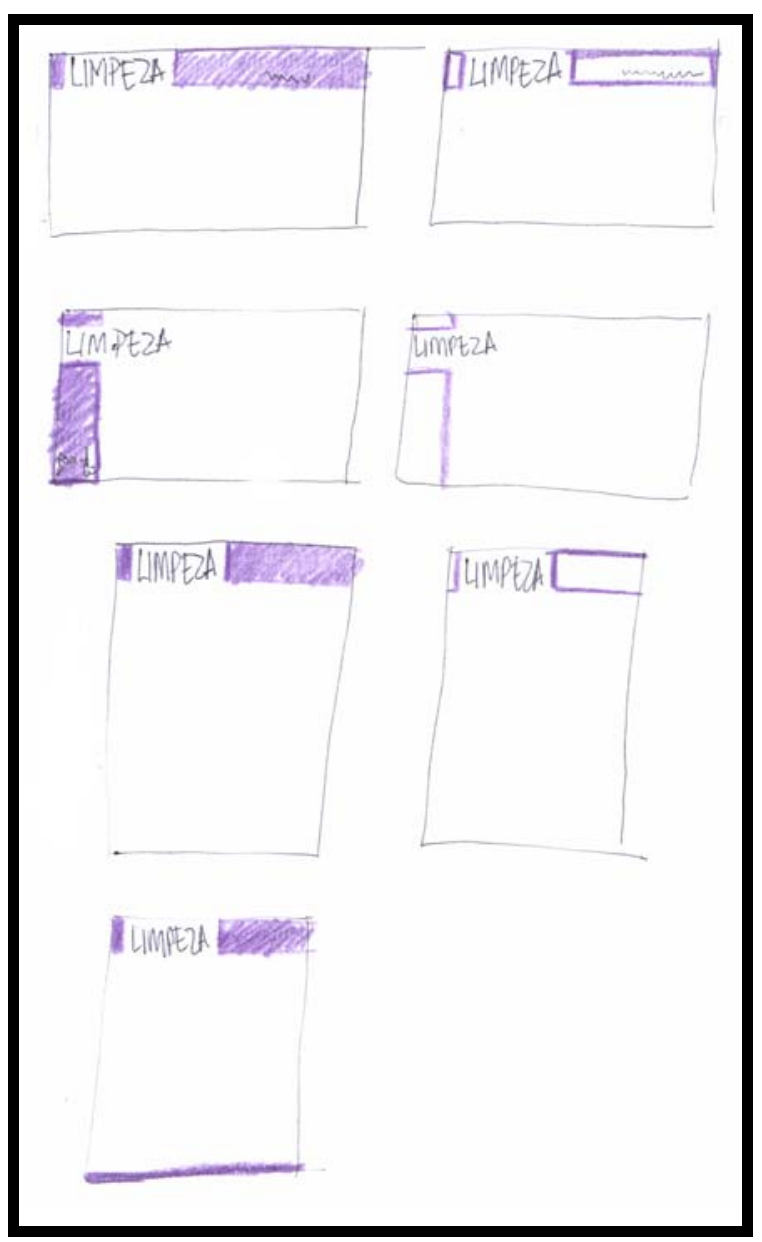

A orientação escolhida foi a orientação horizontal, por disponibilizar uma maior área de trabalho e melhor organização das informações, já que a maior parte das ilustrações e textos tem sua orientação na horizontal.

Depois realizaram-se testes para avaliar a disposição de todos os elementos do conteúdo citados anteriormente. 
Figura 4.40 - Geração de alternativas de leiaute 1

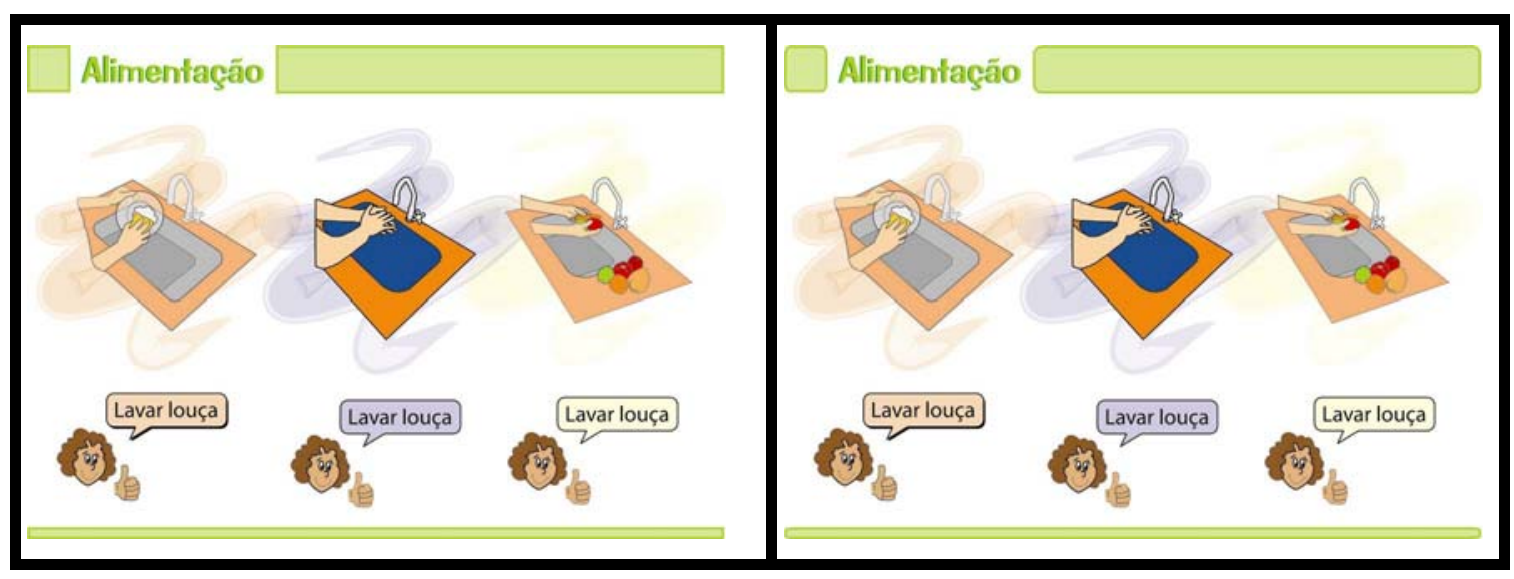

Figura 4.41 - Geração de alternativas de leiaute 2

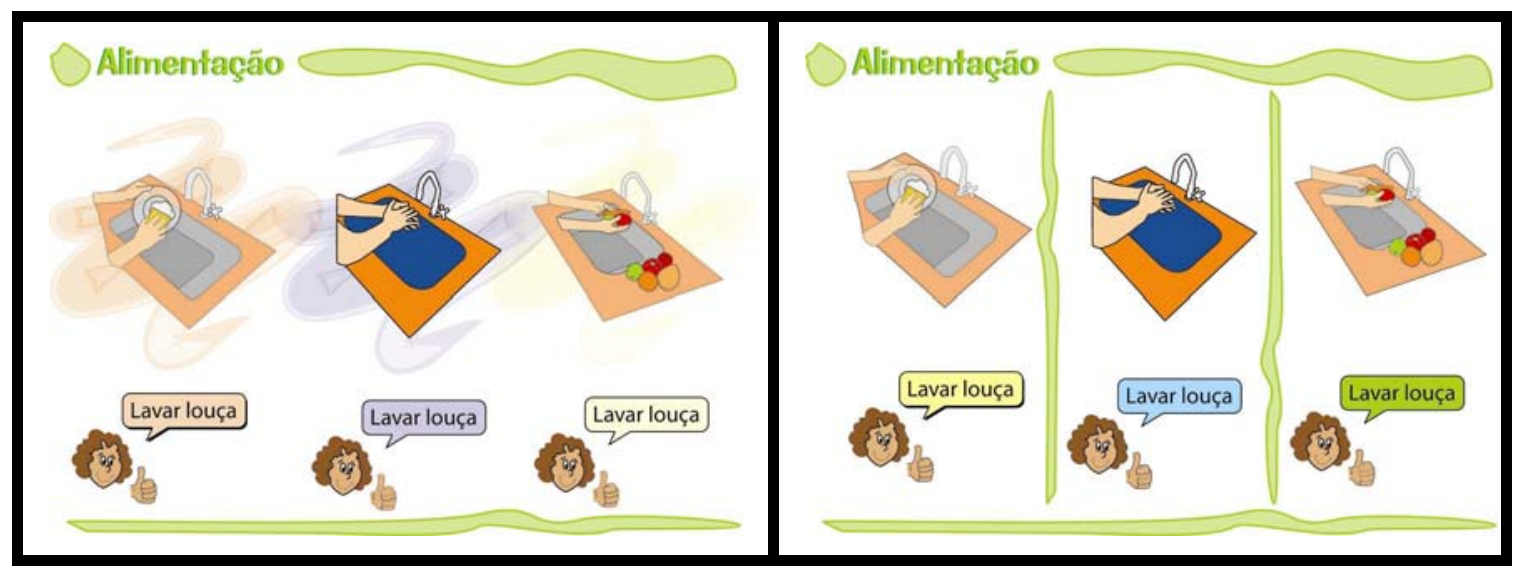

Figura 4.42 - Geração de alternativas de leiaute 3

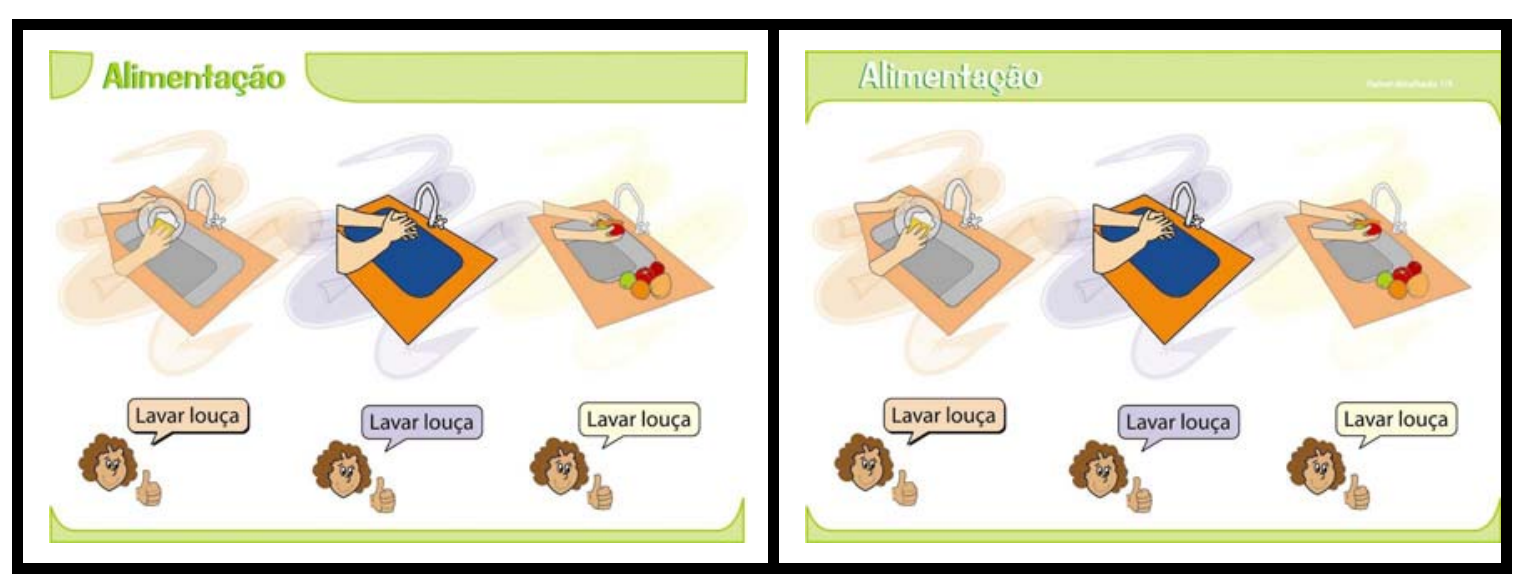


Figura 4.43 - Geração de alternativas de leiaute 4

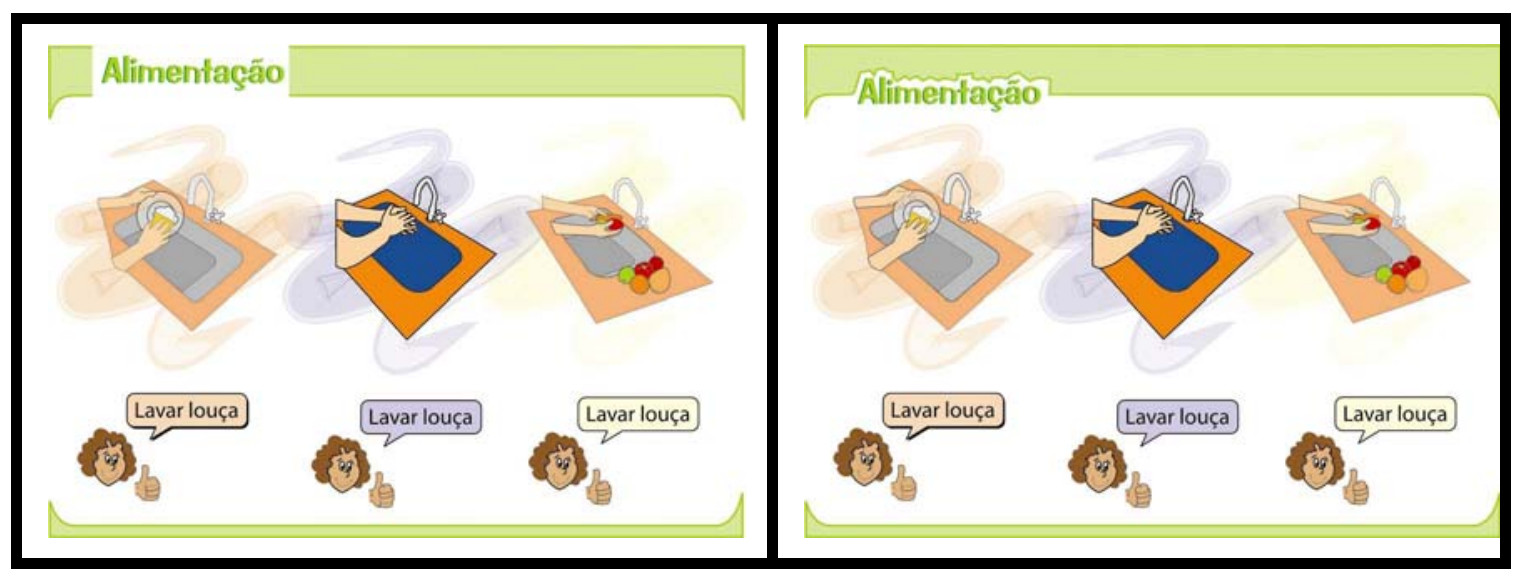

Para a escolha do leiaute final definiu-se que:

- o cabeçalho e o rodapé devem ter as mesmas características de preenchimento e cor do contorno para facilitar a identificação do tema pela cor e para delimitar a área de trabalho com as ilustrações e textos;

- o fundo deve ser colorido e suave atrás das ilustrações, para delimitar a área de abrangência de cada ilustração e intensificar a sua relação com a frase que está em um balão com uma cor semelhante, mas com um tom mais escuro em relação à cor do fundo da ilustração.

Figura 4.44 - Leiaute final

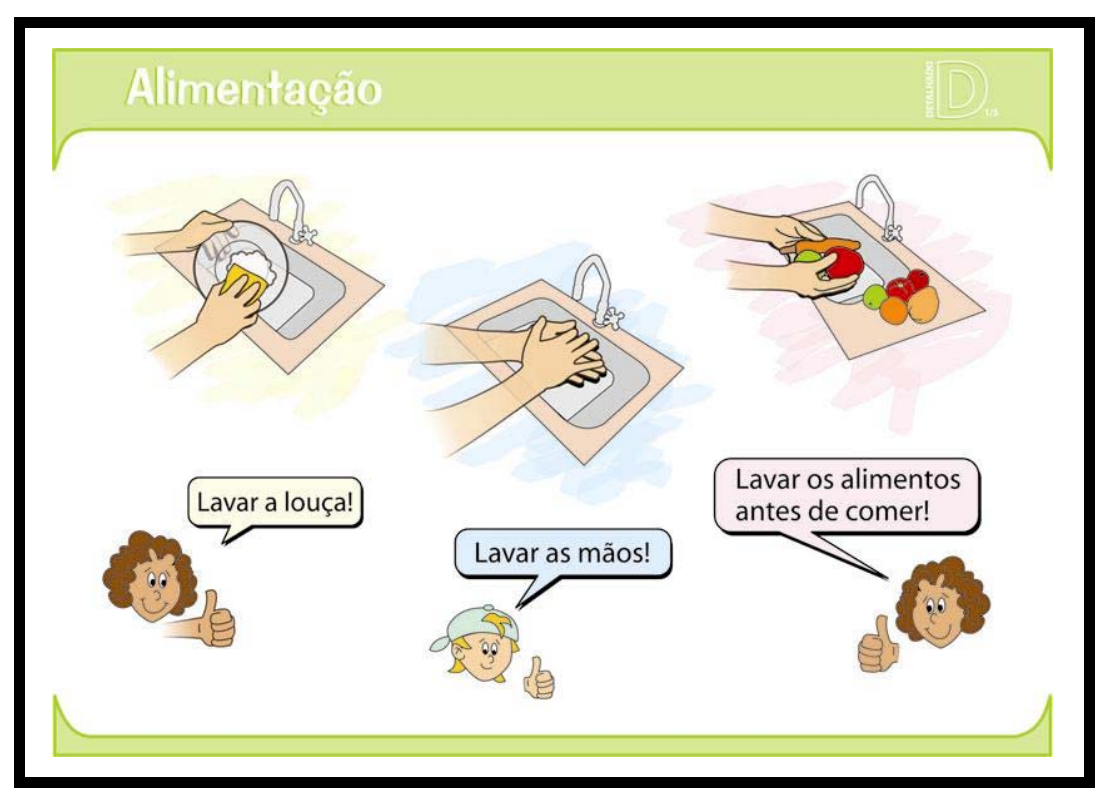




\subsection{Malha gráfica - Grid}

Para desenvolver uma padronização dos leiautes e fortalecer a identidade visual entre os mesmos, delimitou-se uma grid de 6 colunas de 4,75 cm de largura cada, com o espaçamento entre colunas de $1,5 \mathrm{~cm}$ e margens laterais de $3 \mathrm{~cm}$ de cada lado.

Figura 4.45 - Malha Gráfica - Grid

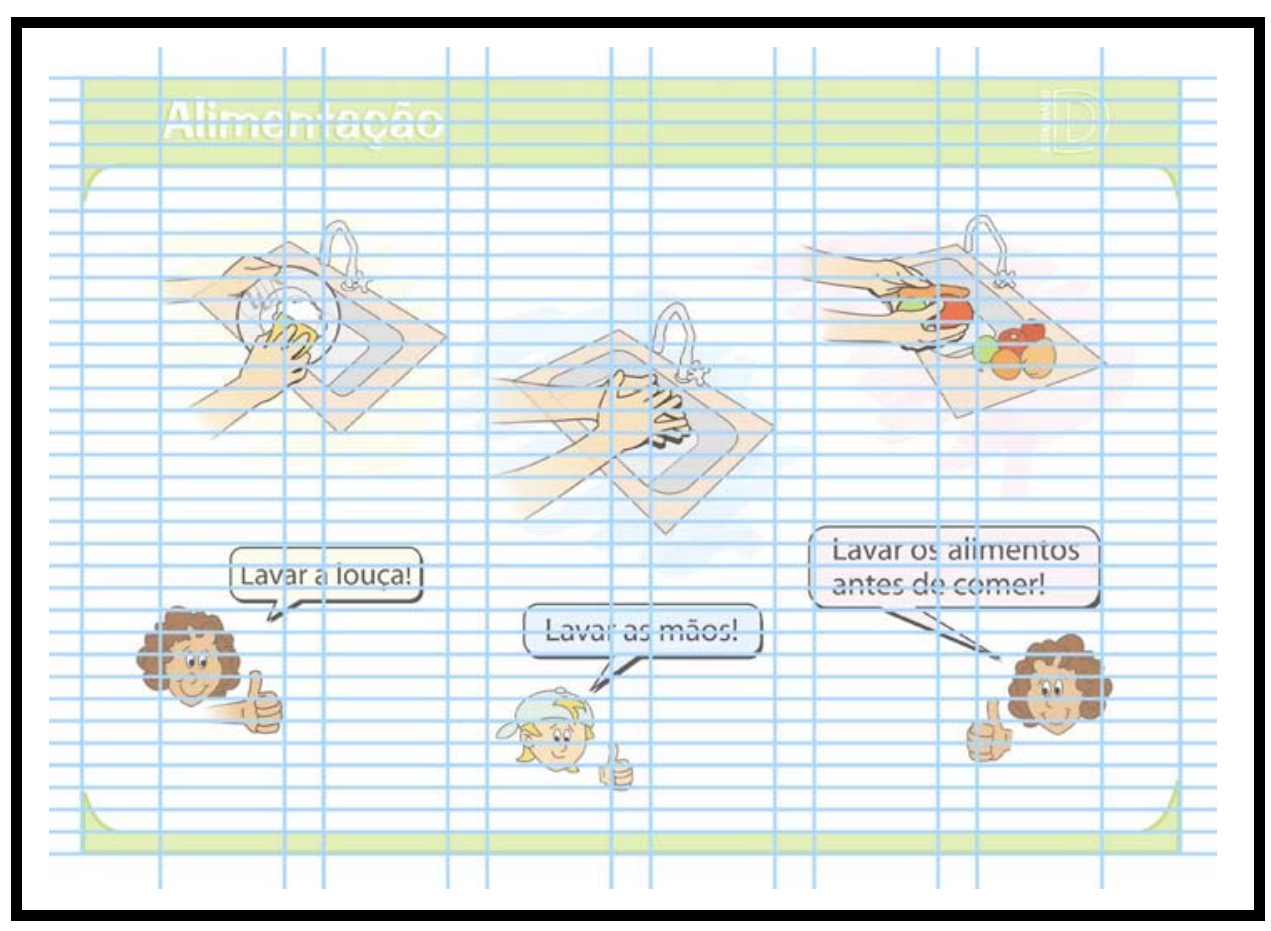

Cada ilustração com sua respectiva frase explicativa deve ocupar o espaço de duas colunas. Deve ser respeitado o espaçamento entre colunas de uma ilustração para outra para que cada ilustração e cada informação possam ser vistas e identificadas claramente.

Foram delimitadas margens laterais de $3 \mathrm{~cm}$ para que se tenha espaço para posicionar os dedos sem cobrir nenhuma informação ou ilustração.

Os personagens que serão utilizados em um dos lados dos painéis, quando existirem apenas duas ilustrações, podem ser posicionados rente às laterais do painel já que sua função é a de reforçar os conceitos de saúde e cuidado e a de associar os painéis à campanha "Amigos para sempre: A Saúde, o Cuidado e Você!”. Como sua função é complementar e de preenchimento, não há problema caso eles sejam em algum momento da explanação cobertos pelas mãos. 


\subsubsection{Jogo}

\subsubsection{A estratégia do jogo}

O jogo foi criado a partir da pesquisa sobre crianças, jogos e brincadeiras, da definição dos requisitos do projeto, da observação das crianças brincando no hospital e da entrevista com os profissionais de saúde. A principal proposta do jogo é que este possibilite a conversa entre crianças e psicólogos sobre assuntos que interessam a esses profissionais, a fim de ajudá-los no atendimento e tratamento das crianças.

Nas entrevistas e observações realizadas, como visto anteriormente, pode-se perceber que a brincadeira é usada pelos psicólogos para “entrar” no mundo da criança e, através da brincadeira, conseguir entender o que a crianças sentem, podendo então auxiliá-las enquanto elas estiverem em tratamento. Percebe-se também que os psicólogos procuram as oportunidades para essa conversa nos jogos e brincadeiras disponíveis e, por vezes, não possuem um material ideal para trabalhar certos assuntos com algumas crianças.

Além disso, o jogo segue a identidade visual da campanha de conscientização sobre saúde: “Amigos para sempre: a Saúde, o Cuidado e Você!”, ou seja, utiliza-se a mesma divisão de assuntos por cores, os personagens, tipografia e formas.

O jogo surgiu baseado nessas observações, com o objetivo de suprir as necessidades observadas no Hospital de Apoio.

O jogo é uma brincadeira de contar estórias. A criatividade é o pré-requisito chave para o jogo e as crianças conseguem explorá-la com facilidade. O jogo tem poucas regras e é cooperativo, ou seja, todos os participantes ganham com a brincadeira. Além disso, possibilita a participação de crianças, pais e psicólogos, bastando apenas ter vontade de brincar e usar a imaginação.

As estórias são baseadas na imaginação de cada participante, que é estimulado através das ilustrações das cartas do jogo. Assim, as cartas abordam temas de saúde, como 
alimentação, higiene e tratamento de doenças, trazendo o assunto para brincadeira e criando um espaço de troca de informações e aprendizado útil principalmente à criança, a qual aprende, com mais facilidade, brincando.

\subsubsection{Geração de alternativas}

A geração de alternativas começa após a definição da estratégia do jogo. Assim é possível pensar nas características formais que ajudem a chegar ao objetivo do jogo. Para uma organização e compreensão didática, divide-se aqui o jogo em quatro componentes básicos: a marca, as cartas, o tabuleiro e a caixa. Dessa forma é possível entender o desenvolvimento de cada componente separadamente, sabendo-se que todos foram desenvolvidos em conjunto no mesmo momento.

\subsubsection{A marca e o nome do jogo}

Para se chegar ao nome do jogo, foi usada a técnica de brainstorming a fim de conseguir variadas idéias e associações de nomes que sugerissem “o contar estórias”. Abaixo pode-se observar alguns dos resultados:

\footnotetext{
“Quem conta um conto aumenta um ponto”

“Quem conta uma estória continua outra”

“Quem pega uma carta aumenta uma fala”

“Escolha a carta e conte sua estória”

"Escute, escolha e conte"

“Escute, pegue e conte!”

"Era uma vez...”

“Conte sua estória!”
}

A partir dessas idéias, voltando-se à estratégia do jogo, percebeu-se que o jogo resumiase a três ações, o de escutar o colega, o de pegar uma carta e o de contar a estória. Assim, 
optou-se por essas ações principalmente por ser um nome que já explica a essência do jogo. O nome escolhido é: Escute! Pegue! Conte!. Os verbos no imperativo e as pontuações “exclamação” reforçam o convite direto ao participante.

Como há um nome, deve existir uma marca, ou seja, uma forma de representar esse nome. Para o desenvolvimento de uma marca, há muitos passos, estudos, pesquisas e observações importantes a serem levados em conta. Porém, como se trata da marca do jogo que é um produto entre outros desse projeto, a marca foi pensada de forma simples, para representar o nome e identificar o jogo, tendo, o verso das cartas como aplicação principal.

Figura 4.46 - Primeiras marcas do jogo

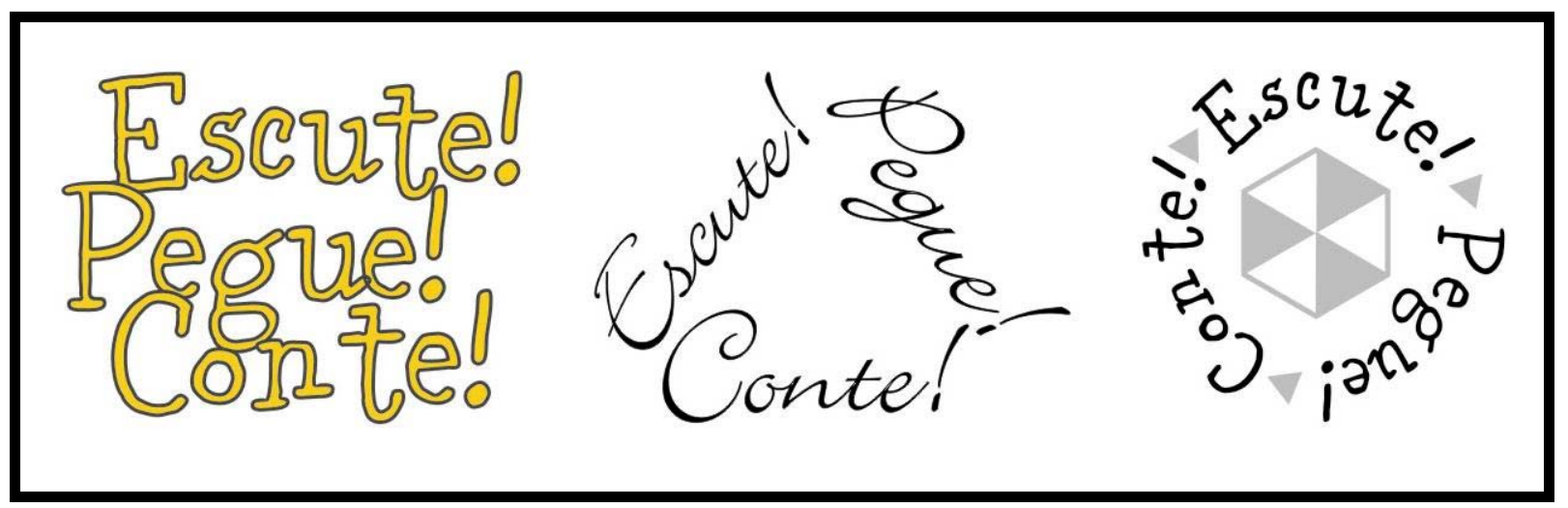

A primeira alternativa usou uma fonte fantasia, “carnation”, preenchida de amarelo. A fonte lembra brincadeira e crianças. O amarelo, além de estimular a comunicação, é uma cor primária e atrativa, de boa visualização para as crianças. As palavras foram organizadas de modo a percebê-las separadamente e em conjunto.

A segunda alternativa usou a forma geométrica triangular (três lados) para organizar as três ações e ainda uma fonte associada a contos de fadas quando se escrevem "Era uma vez...”

A terceira alternativa organiza a marca em triângulos e hexágonos, e cria um símbolo. O símbolo é o hexágono com os três triângulos. O hexágono é uma forma presente no jogo, como poderá ser visto em seguida e os três triângulos simbolizam as três ações do jogo. 
Nenhuma geração conseguiu representar o jogo segundo sua estratégia. A terceira geração conseguiu representar melhor, porém seu desenho remete ao símbolo de radiação já existente. Assim, a partir dessa terceira geração, novas formas foram criadas.

Figura 4.47 - Continuação geração marcas do jogo

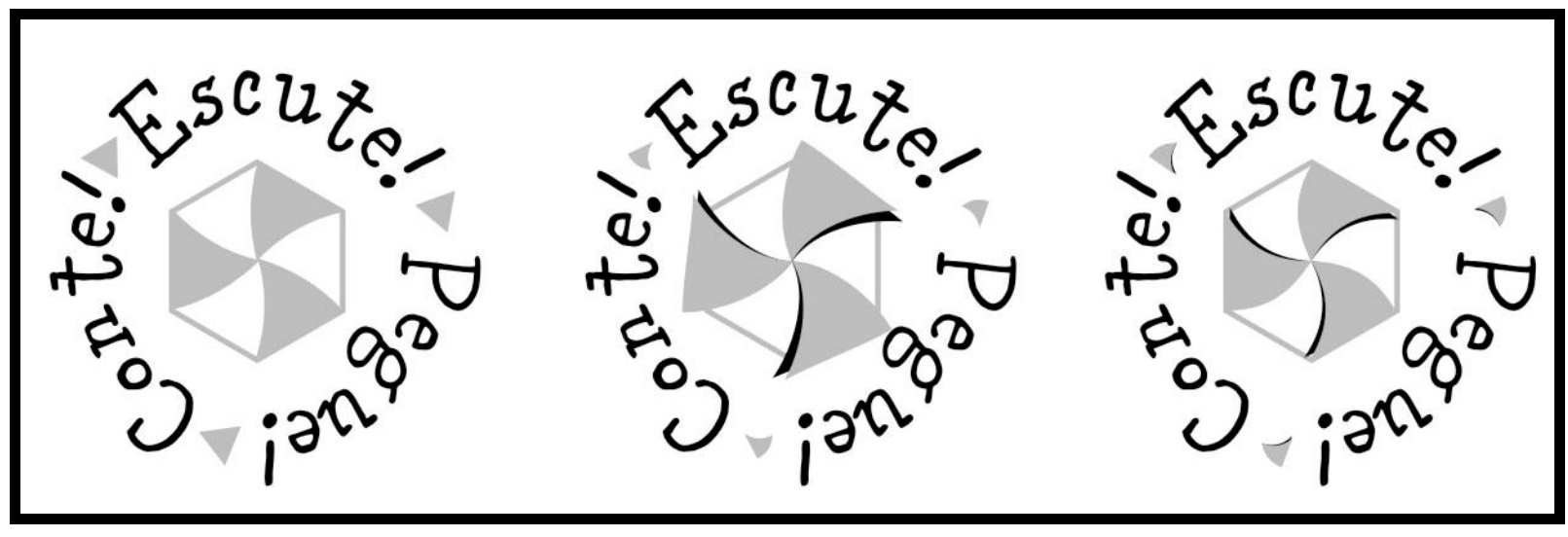

Como se pode observar acima, a marca foi sofrendo alterações em suas linhas retas, passando para linhas curvas assim como sombras foram usadas para evidenciar as formas. $\mathrm{O}$ desenho dos triângulos transformou-se na idéia de um cata-vento, brincadeira de criança. A marca agora se identifica com o jogo e simboliza as três ações do jogo presentes em seu nome.

Figura 4.48 - Marca final do jogo

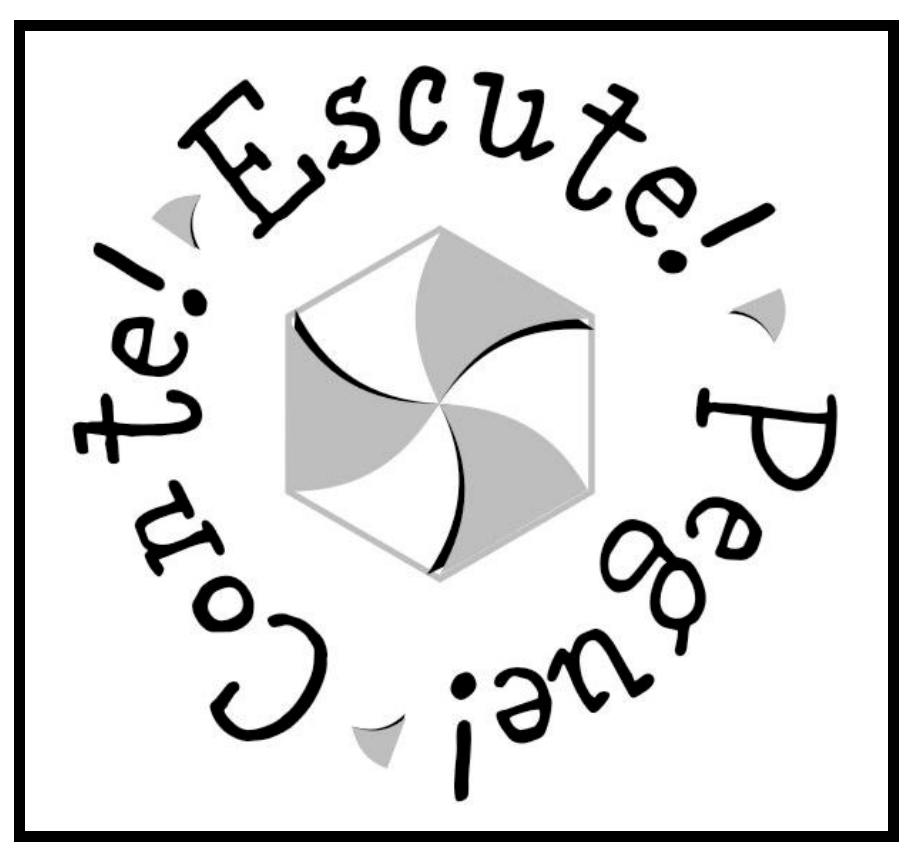




\subsubsection{As cartas}

As cartas do jogo têm frente e verso. A idéia é que na frente estejam as ilustrações e no verso a marca do jogo.

As cores das cartas no contorno e preenchimento seguem a formatação dos painéis explicativos já desenvolvidos para os grupos informativos. Os assuntos dos painéis foram divididos em temas e esses temas em cores, que continuam presentes aqui no jogo. Isso é possível porque o jogo trabalha com os mesmos assuntos da campanha.

A geração de alternativas das cartas, então, focou-se na forma das cartas e no leiaute do verso da mesma.

Figura 4.49 - Carta do jogo 1

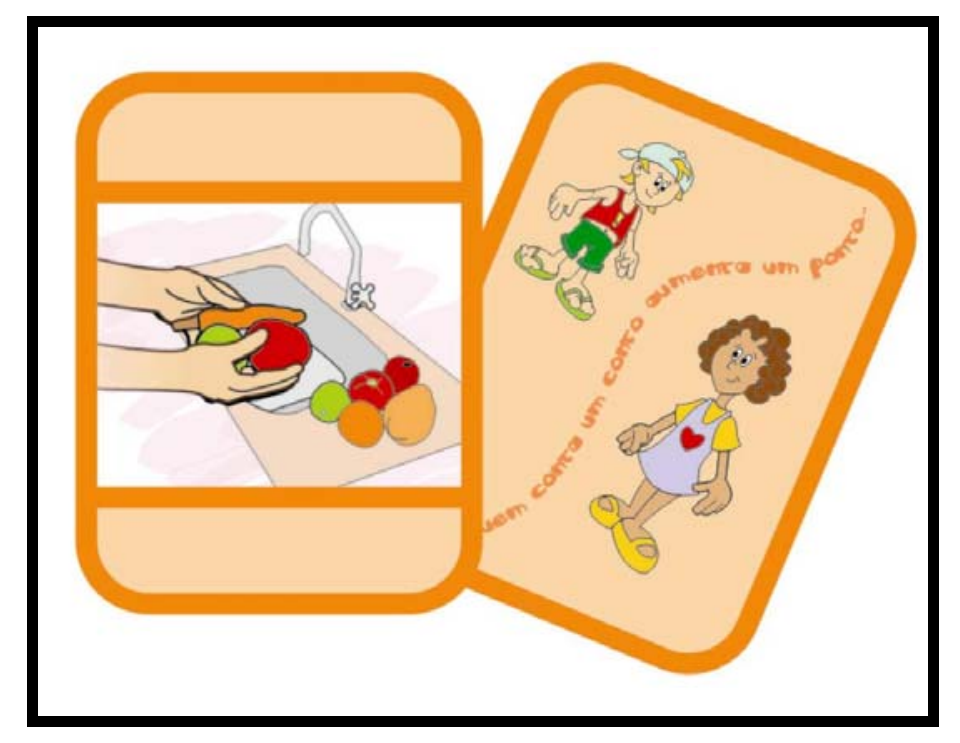

A carta segue uma forma tradicional, retangular, no sentido vertical. Insere a ilustração na frente e, no verso, usa os personagens e uma primeira idéia para o nome do jogo. Como o jogo procura estimular a criatividade, a forma da carta retangular não oferece muitas possibilidades de organização. O mesmo acontece com a forma quadrada observada na figura 4.50 . 
Figura 4.50 - Carta do jogo 2

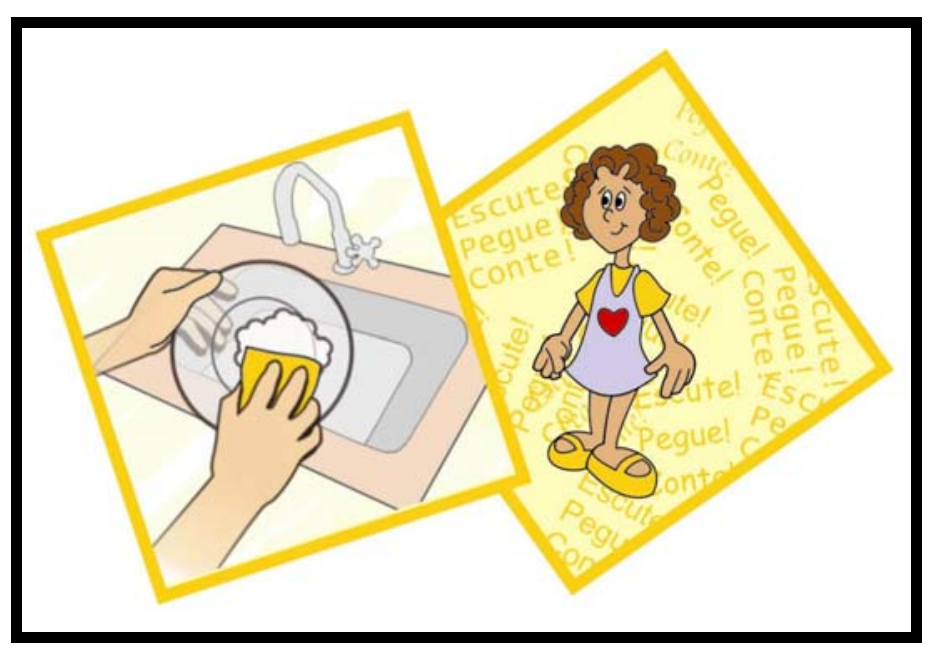

Figura 4.51 - Carta do jogo 3

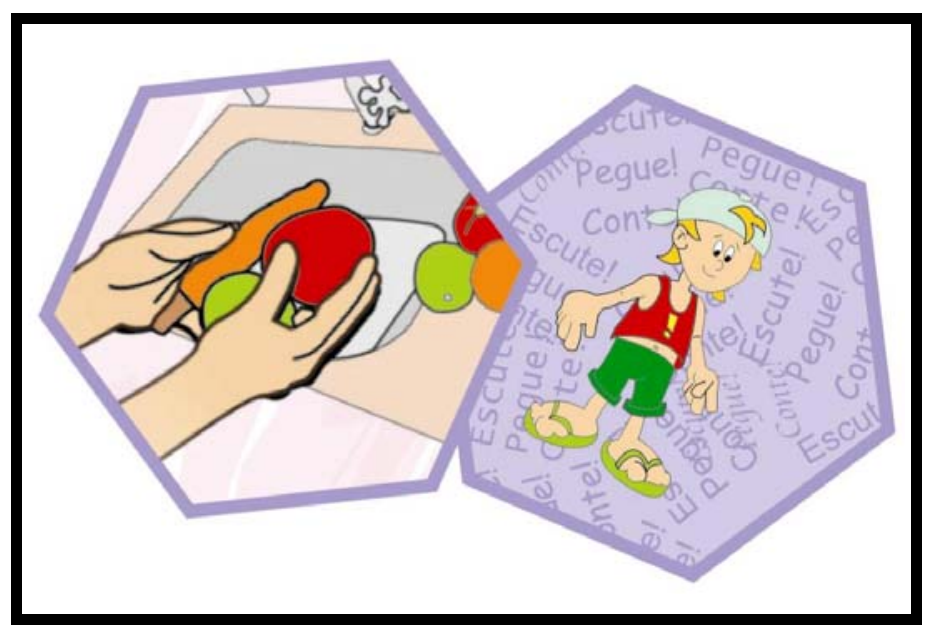

Na figuras 4.50 e 4.51, o verso apresenta a saúde e o cuidado, separadamente, e uma repetição do nome do jogo. Na frente, a ilustração já preenche todo o espaço da carta. O espaço é, portanto, bem aproveitado. 
Figura 4.52 - Verso da carta do jogo 1

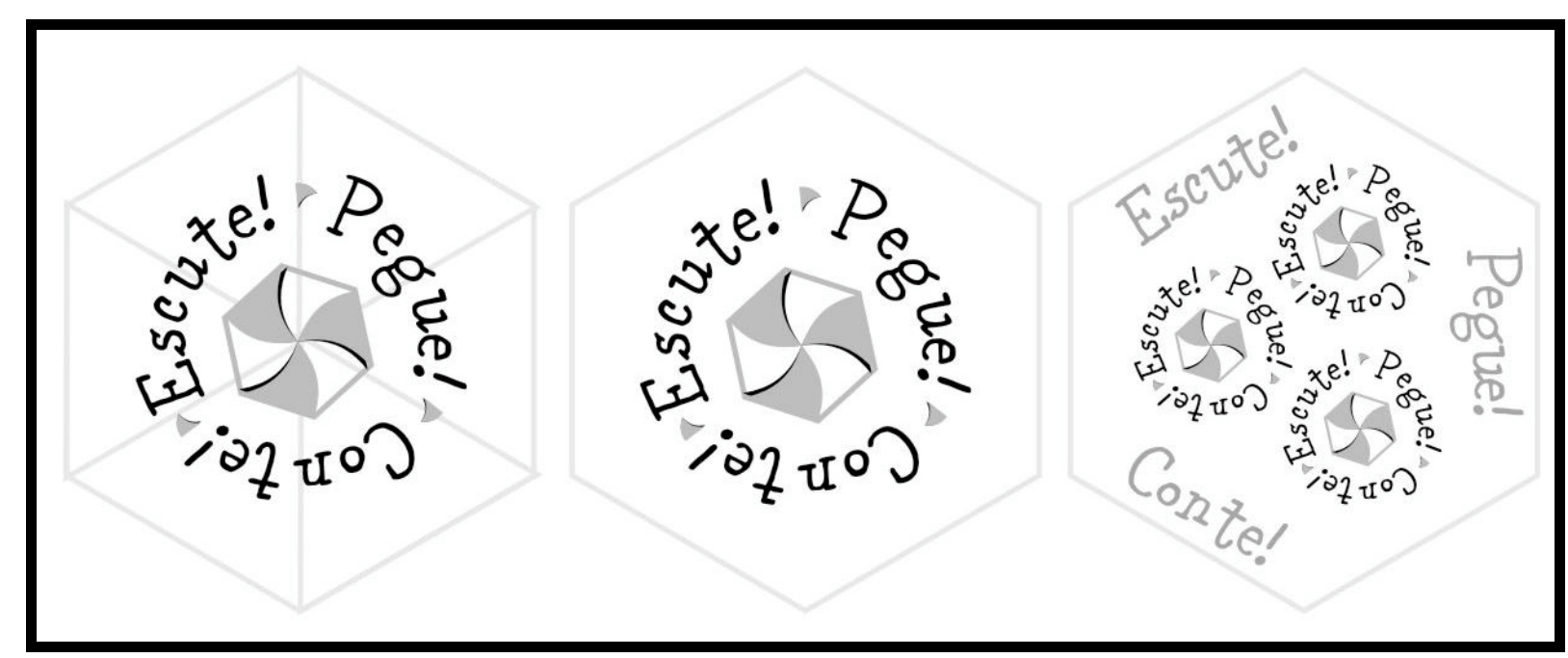

Figura 4.53 - Verso da carta do jogo 2

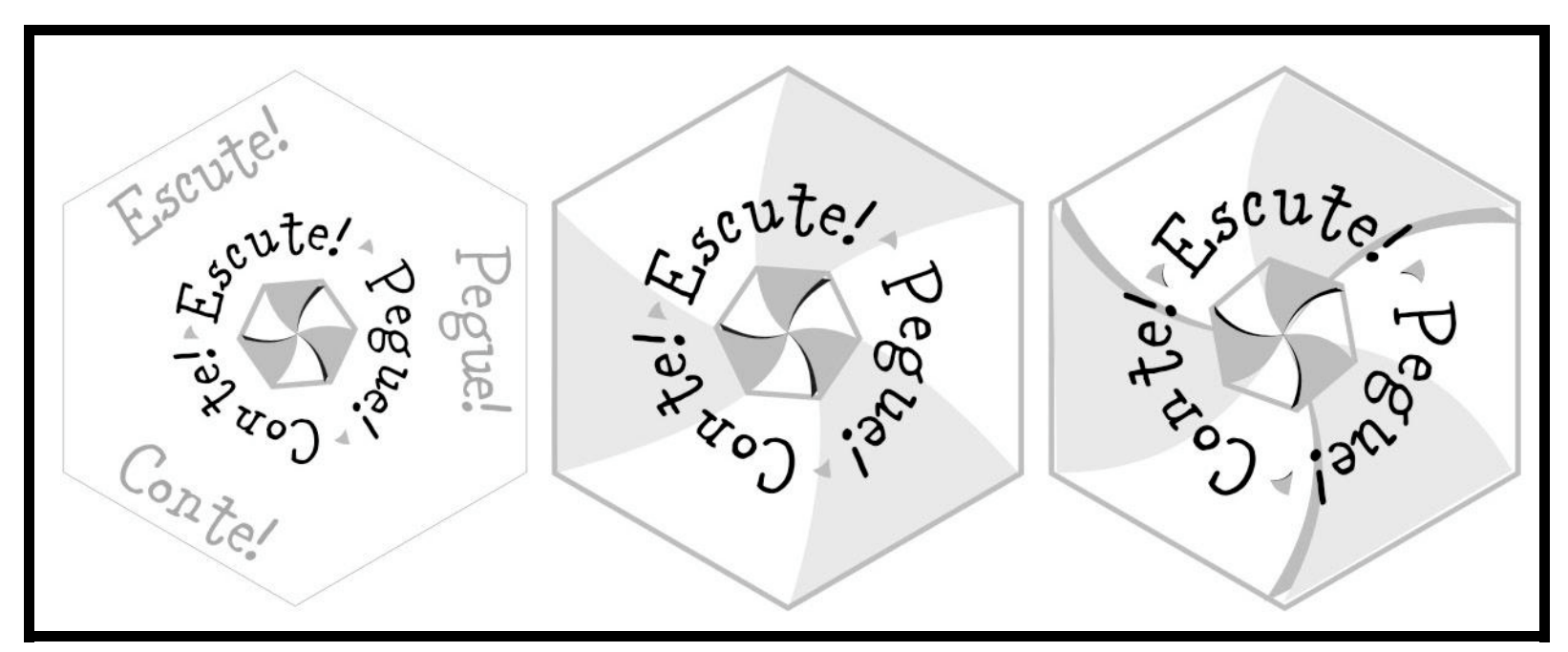

Nas figuras 4.52 e 4.53, há alguns estudos de leiaute do verso das cartas, mantendo a monocromia, e o uso apenas da marca, sem os personagens Saúde e Cuidado. 
Figura 4.54 - Geração carta 1

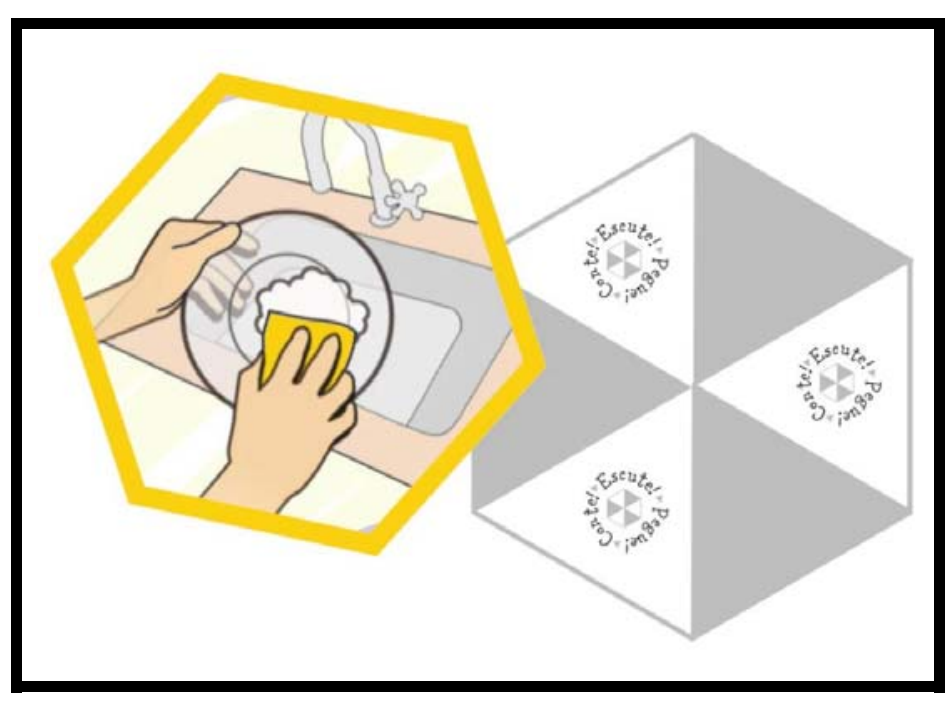

Figura 4.55 - Geração carta 2

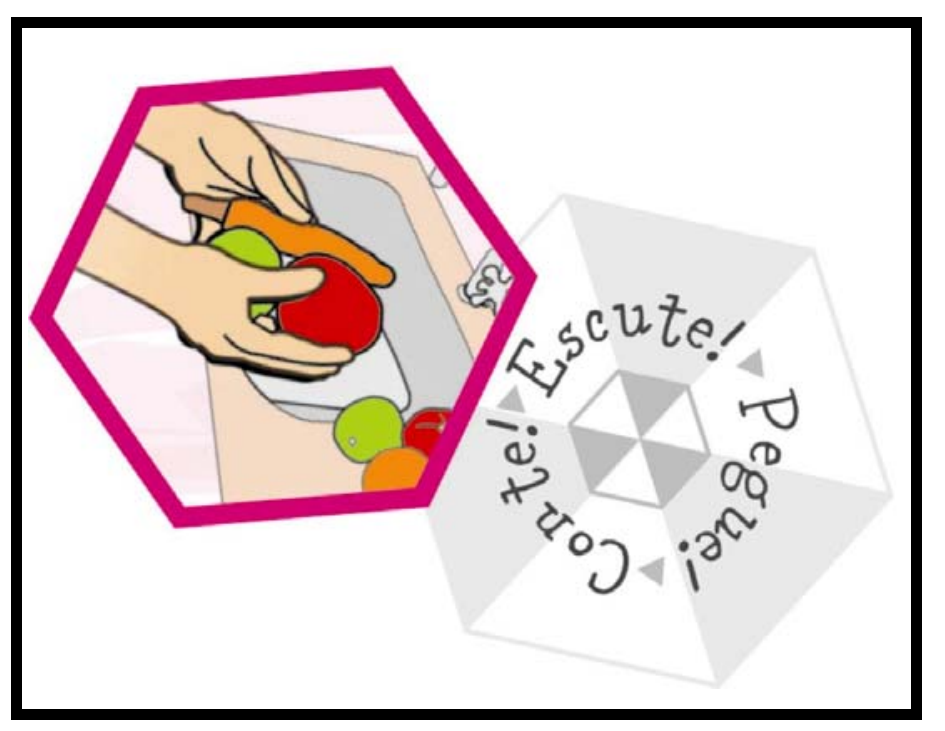

A forma hexagonal das cartas permite organizações variadas. O verso trabalha as formas da marca e a própria marca em apenas uma cor, o preto. 
Figura 4.56 - Carta final

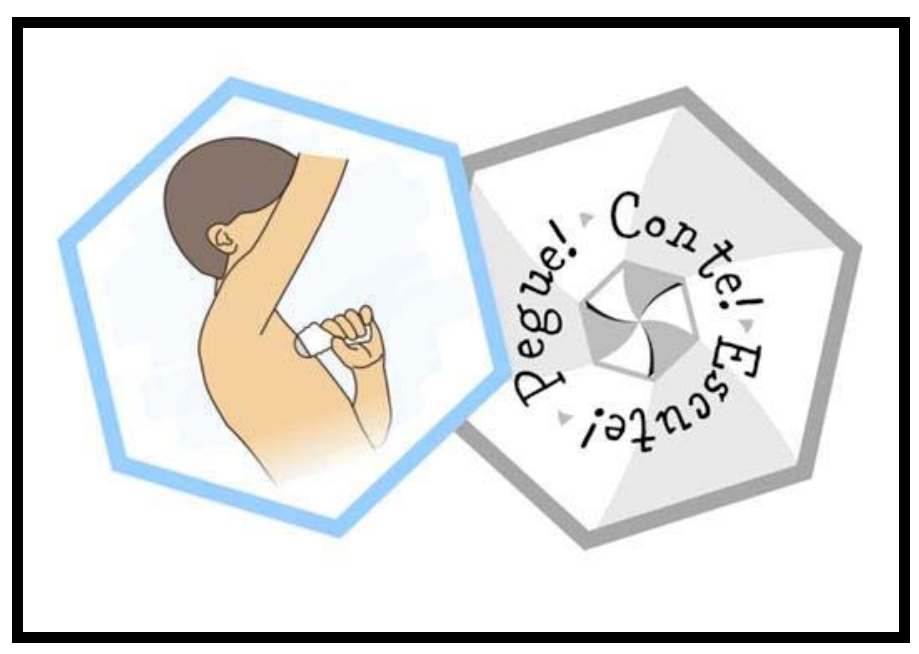

Na figura 4.56 pode-se observar a carta finalizada. Forma hexagonal, verso em preto. Frente e verso com contornos definidos. Ilustração preenchendo toda a carta.

Nas figuras 4.57 a 4.59 é possível visualizar fotos das cartas do jogo já confeccionadas.

Figura 4.57 - Cartas no tabuleiro

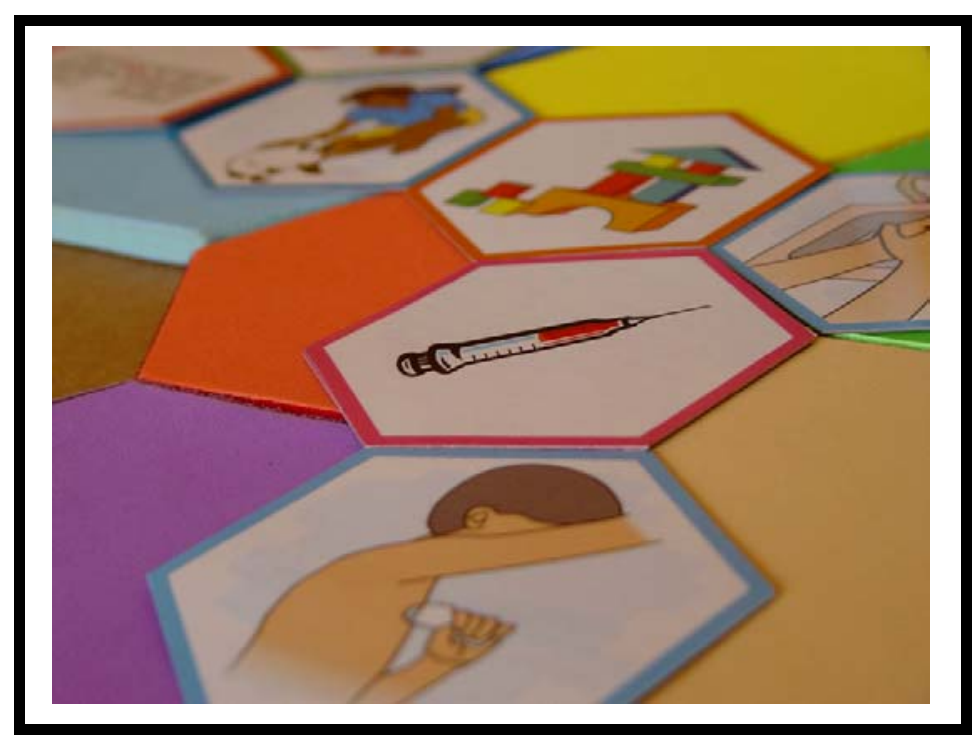


Figura 4.58 - Cartas início e fim

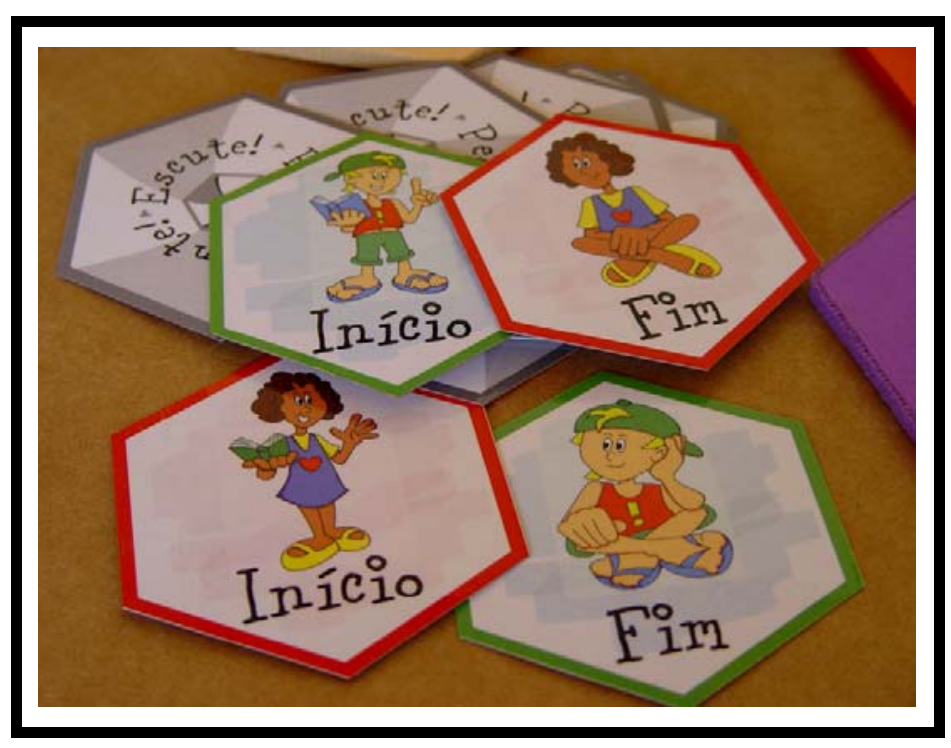

Figura 4.59 - Cartas - verso e frente

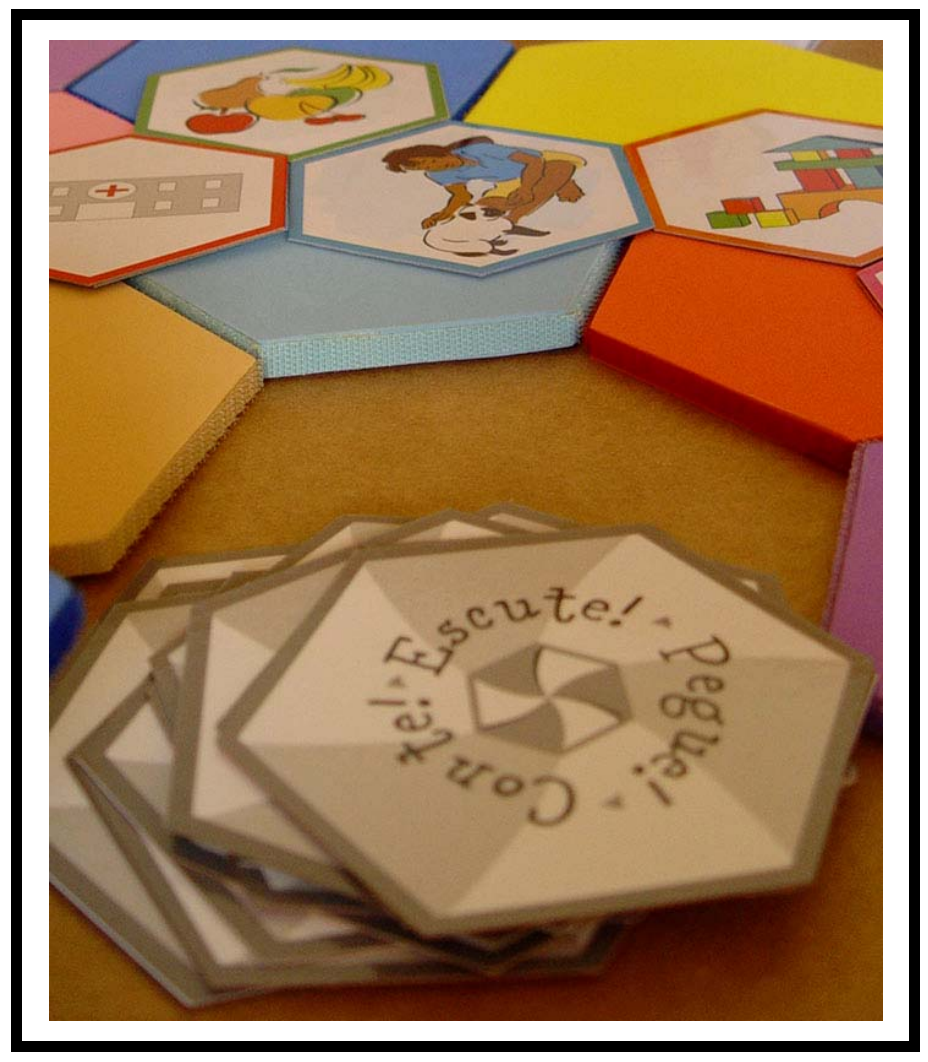

\subsubsection{O tabuleiro}

O tabuleiro tem as funções de concretizar um espaço para a brincadeira acontecer, de receber as cartas dos participantes e de mostrar o caminho que a estória vai seguir de acordo com a sua organização e a organização das cartas. 
Figura 4.60 - Tabuleiro do jogo 1

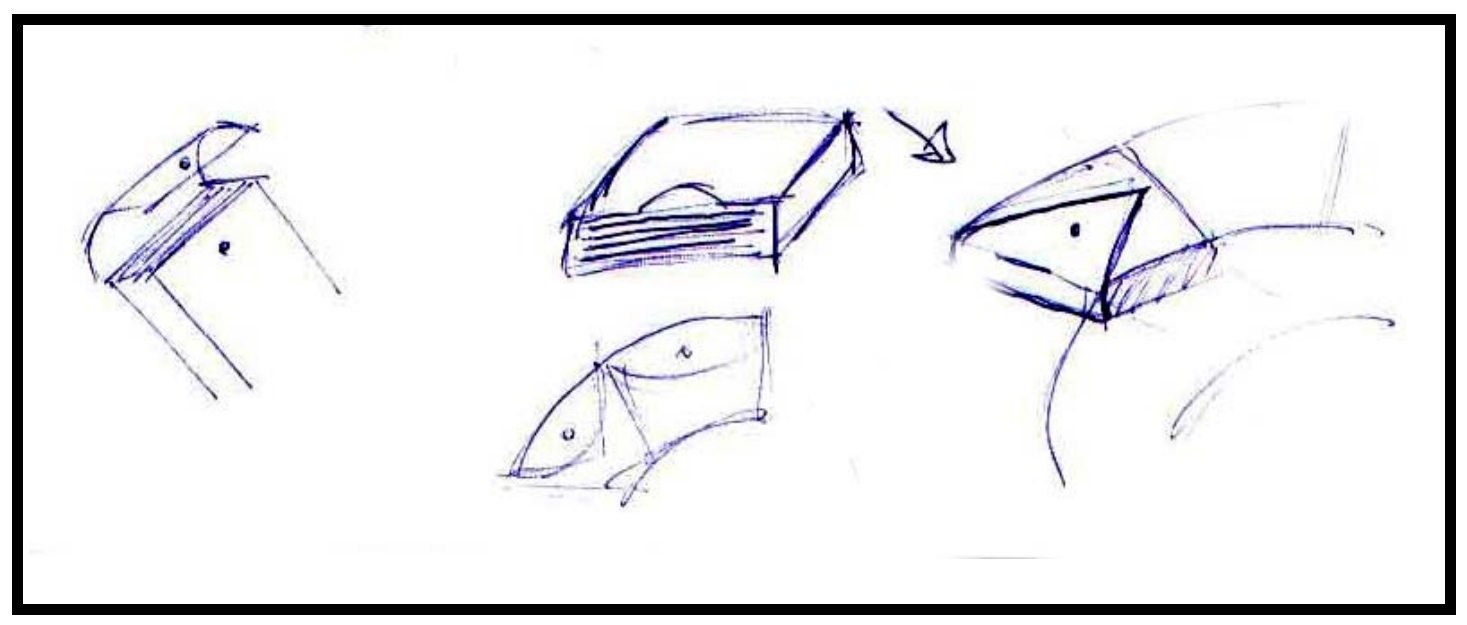

Figura 4.61 - Tabuleiro do jogo 1.1

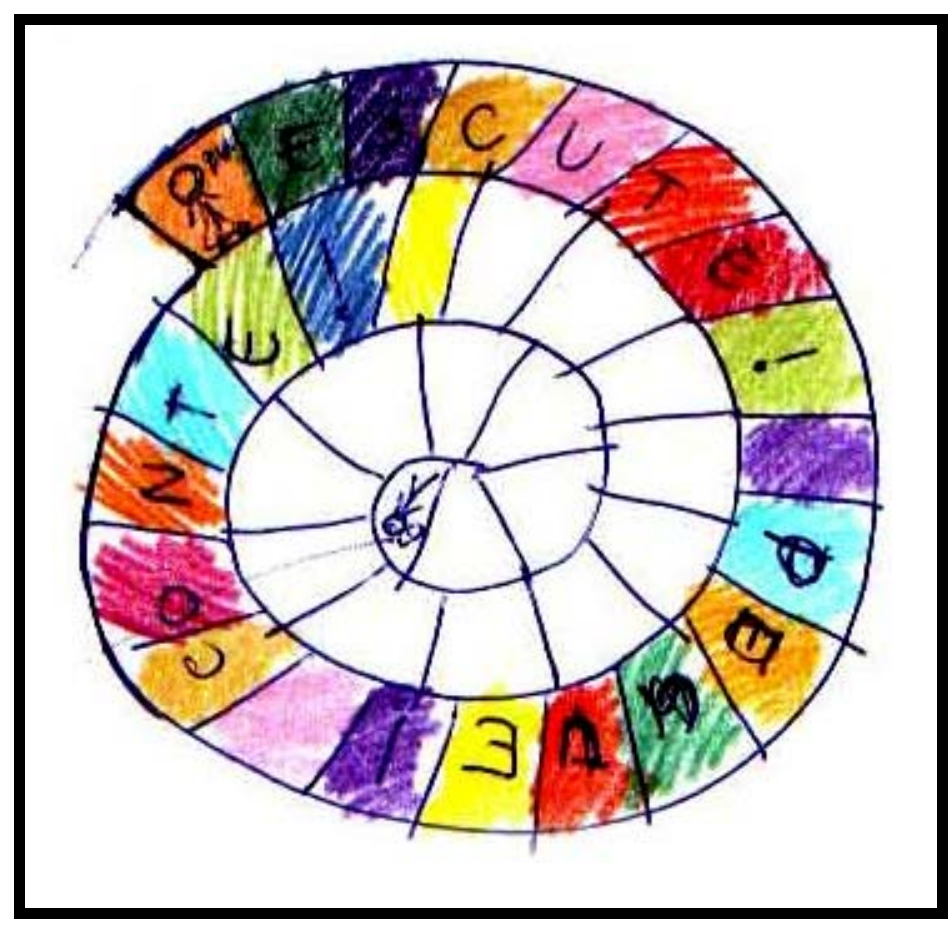

Na primeira alternativa, o tabuleiro é uma espécie de caracol que se dobra e fecha guardando as cartas e, ao abrir, esse se desenrola fazendo o caminho da estória. Essa geração resolve bem o problema do caminho, porém o restringe visto que só há uma possibilidade de caminho para a estória, além de também delimitar a forma da carta. 
Figura 4.62 - Tabuleiro do jogo 2

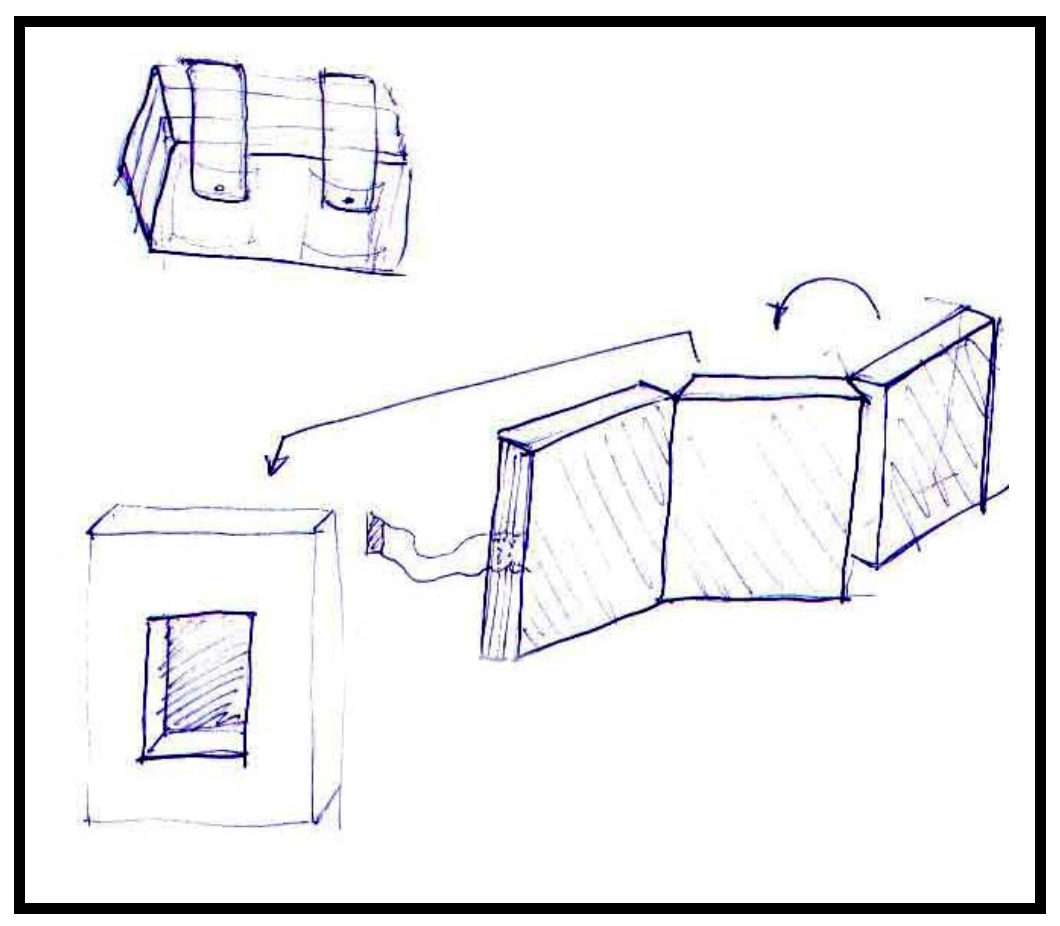

Figura 4.63 - Tabuleiro do jogo 2.2

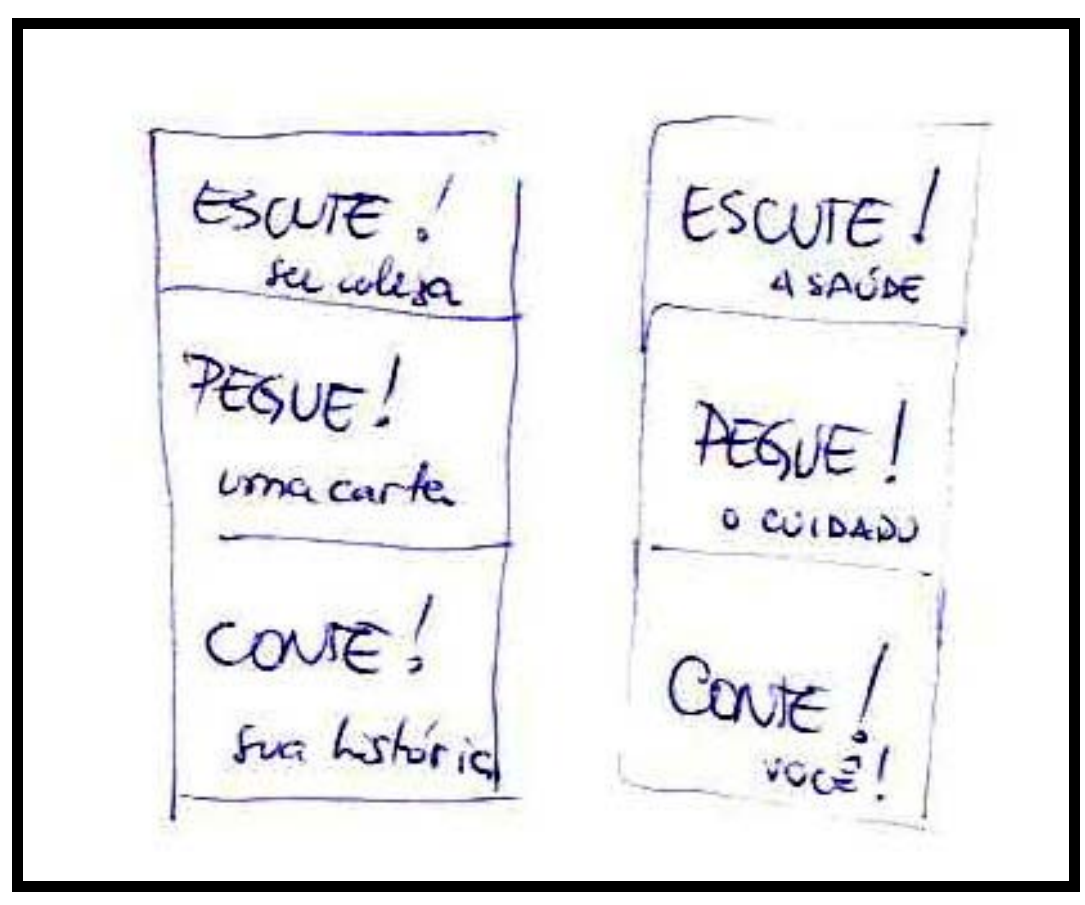

Na segunda alternativa, o tabuleiro se divide em três, para evidenciar as três ações do jogo. Nessa geração preocupou-se apenas com a forma e não com o leiaute. 
Figura 4.64 - Tabuleiro do jogo 3

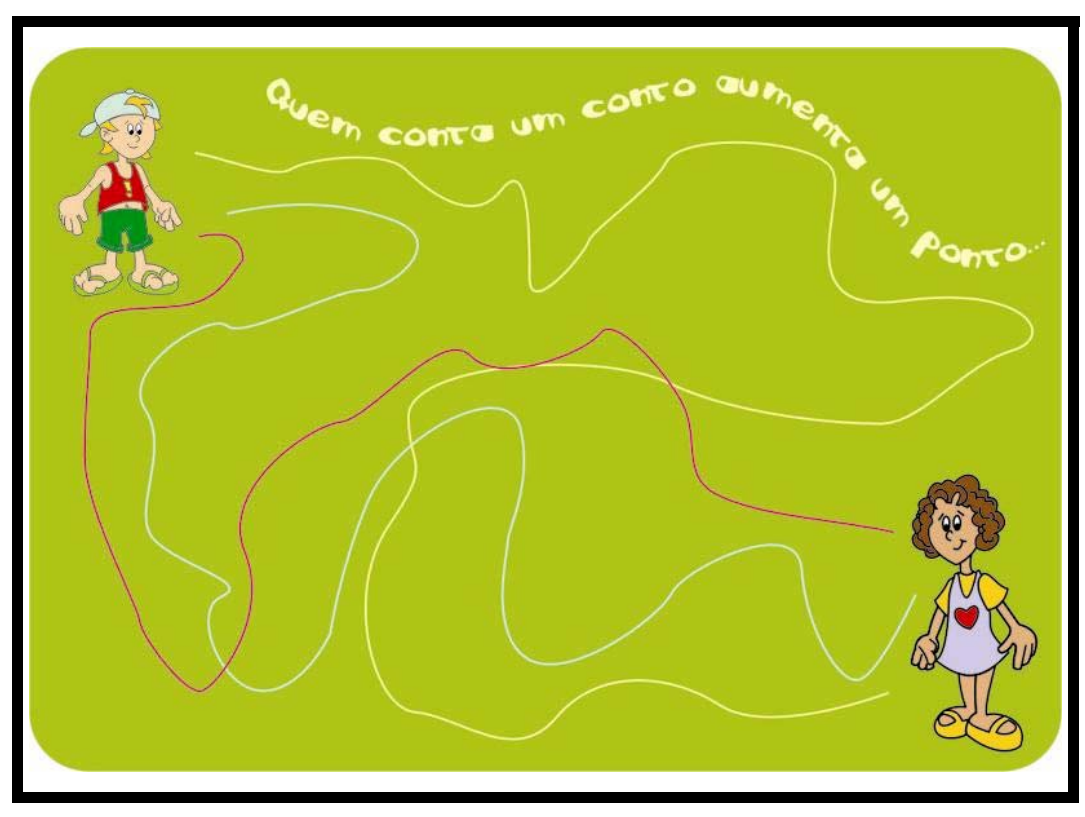

A terceira alternativa apresenta um tabuleiro comum, plano; a Saúde em um canto, no início da brincadeira; e o Cuidado no outro canto, no fim da estória. A idéia desse tabuleiro remete à tradicional brincadeira de crianças com telefone de latas e barbante (telefone). Há três diferentes formas de trilhar o caminho com as cartas, como se a Saúde estivesse contando uma estória ao Cuidado. Essa geração aproxima mais os personagens ao jogo e já possibilita outros caminhos.

Figura 4.65 - Tabuleiro do jogo 4

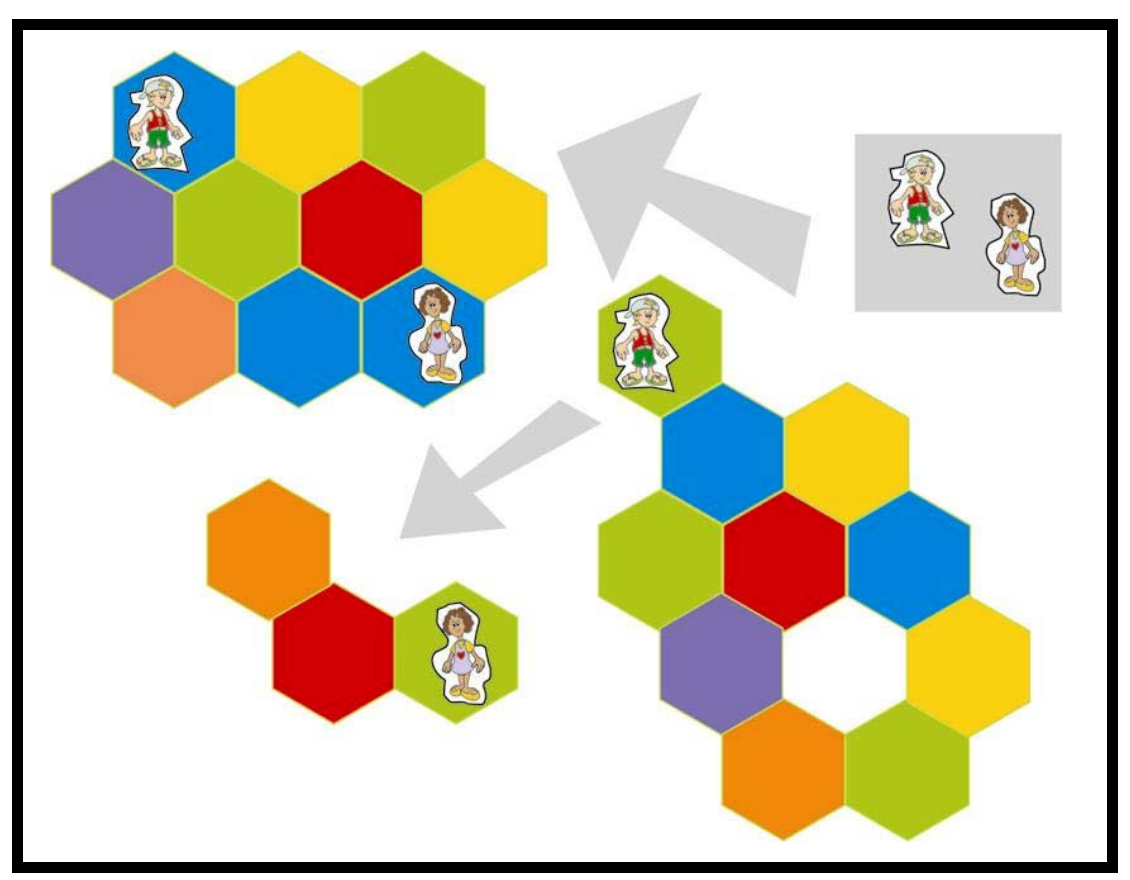


Essa última alternativa apresenta o tabuleiro não como uma peça única, mas vários hexágonos coloridos que podem ser montados de diversas formas, de acordo com a criatividade dos participantes. A Saúde e o Cuidado também se encontram no tabuleiro, mas como cartas que podem ser escolhidas onde ficar. Dessa forma, o tabuleiro consegue funcionar como esperado, trilhando o caminho, sendo a base das cartas, mas não podando a liberdade e criatividade dos participantes.

\subsubsection{A caixa}

A caixa é a embalagem do jogo. Ela tem uma função principal que é a de chamar a atenção da criança. Ela deve convidar à criança para brincar com o seu visual, sua forma e cores. Nesse caso a caixa tem as funções de armazenar as peças do tabuleiro e as cartas do jogo, de proteger os componentes do jogo, de conter as regras do jogo e de ser atrativa às crianças. Outro aspecto importante é o de manter uma identidade com o jogo Escute! Pegue! Conte!, com a marca e com a campanha “Amigos para sempre: A Saúde, o Cuidado e Você!”.

A geração de alternativas focou-se no leiaute da caixa. A forma da caixa é um volume hexagonal, já que as cartas, as peças do tabuleiro e a própria marca do jogo obedecem a essa forma.

Na primeira alternativa a marca do jogo é repetida e as cores aplicadas em cada lado do hexágono. As laterais têm a marca aplicada como no verso das cartas do jogo. 
Figura 4.66 - Caixa do jogo 1

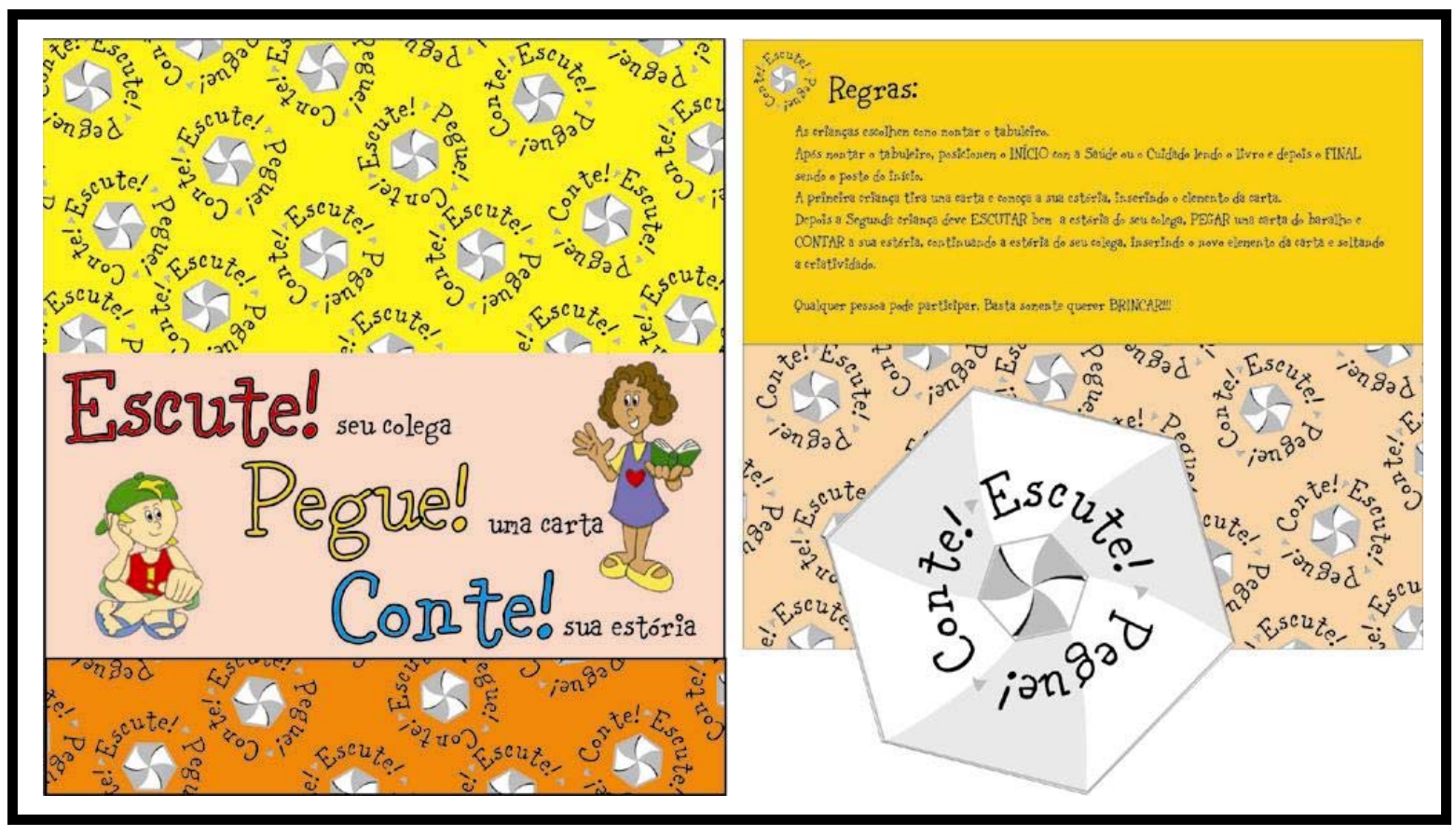

Na segunda alternativa o leiaute baseia-se nas cores das peças do tabuleiro e do efeito “arco-íris” a que remetem quando estão juntos. As laterais repetem o mesmo leiaute. 
Figura 4.67 - Caixa do jogo 2

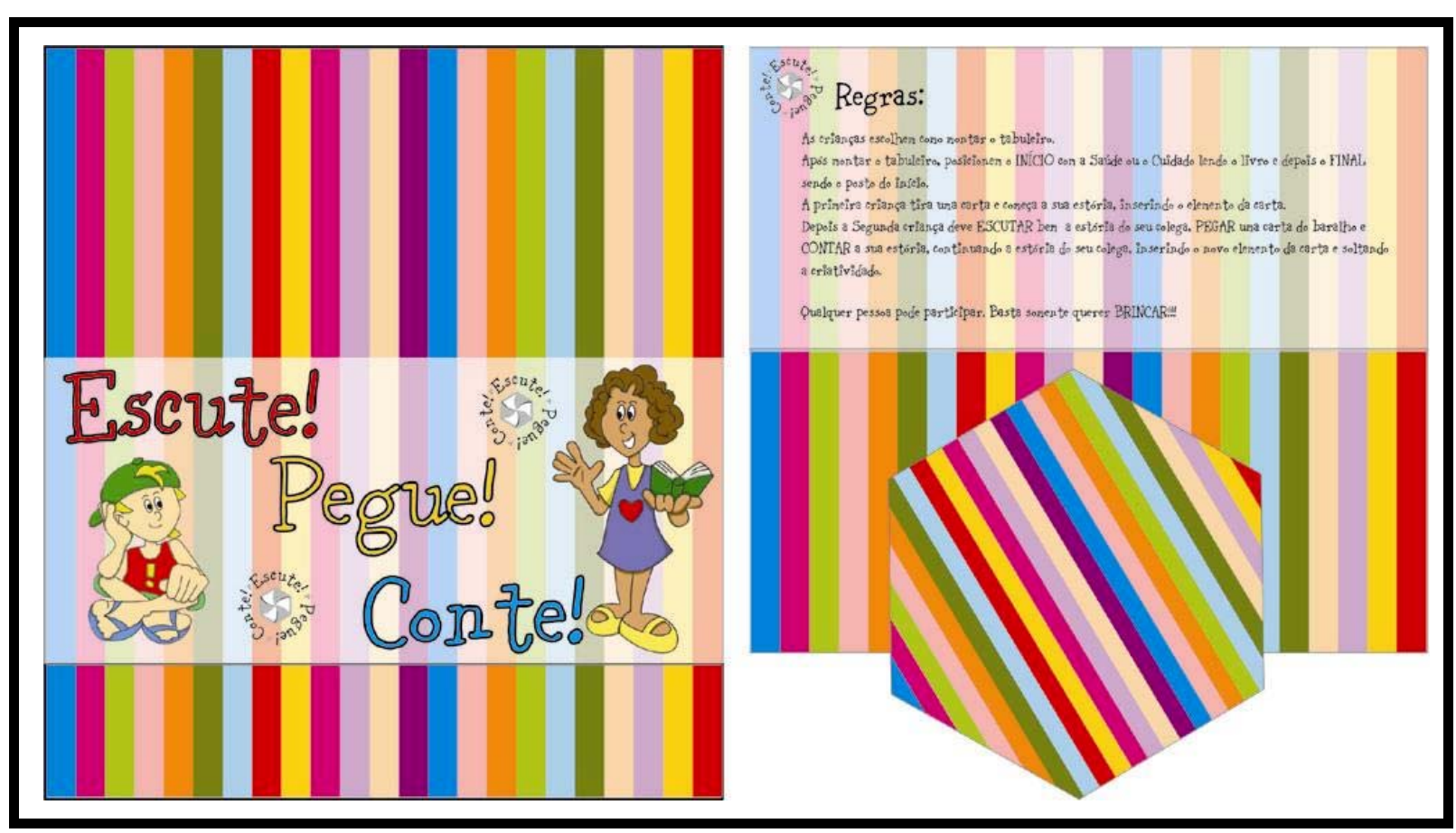

Na terceira alternativa o leiaute da caixa é aproveitado para já sugerir diferentes formas de organizar o tabuleiro. Além de incentivar o participante a criar novas formas, a organização dos hexágonos de forma harmoniosa deixa a caixa atrativa e colorida.

Nas imagens 4.69 a 4.71 pode-se visualizar as fotos da caixa já confeccionada. 
Figura 4.68 - Caixa do jogo final

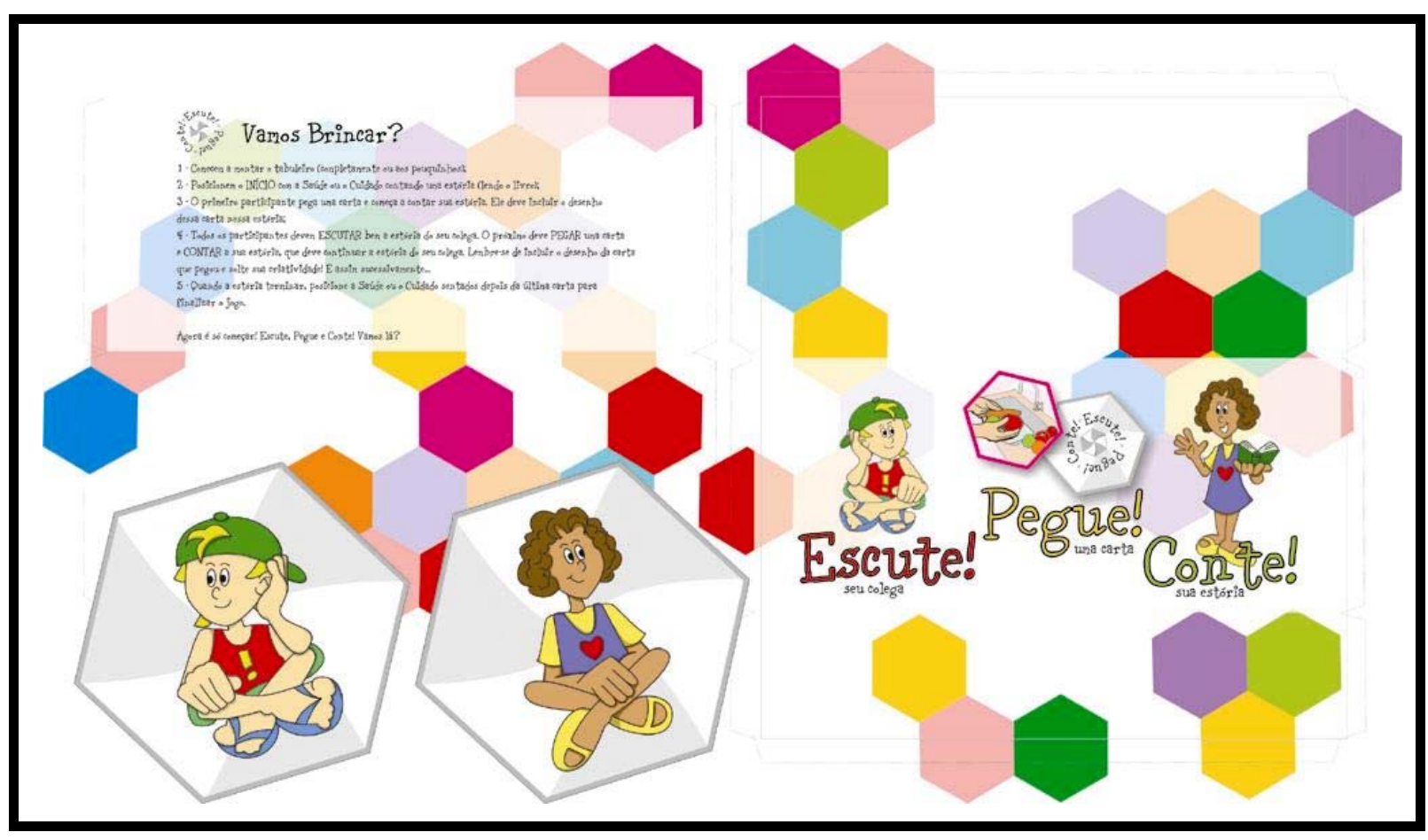

Figura 4.69- Caixa do jogo real 1

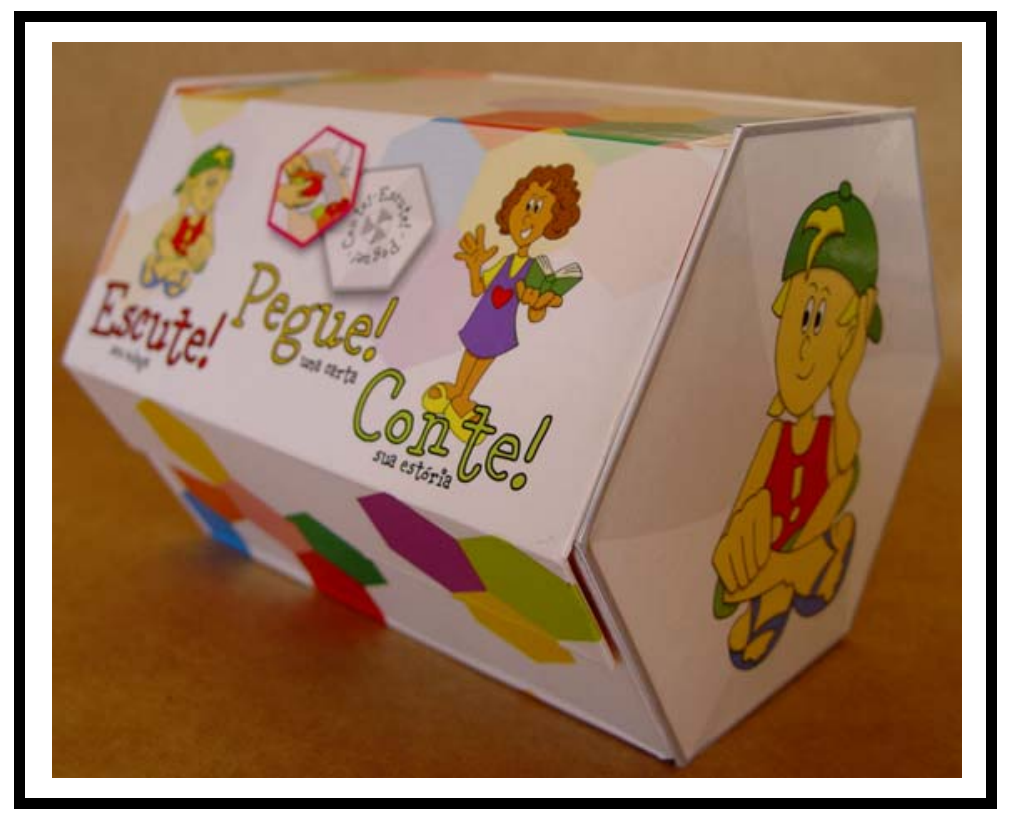


Figura 4.70- Caixa do jogo real 2

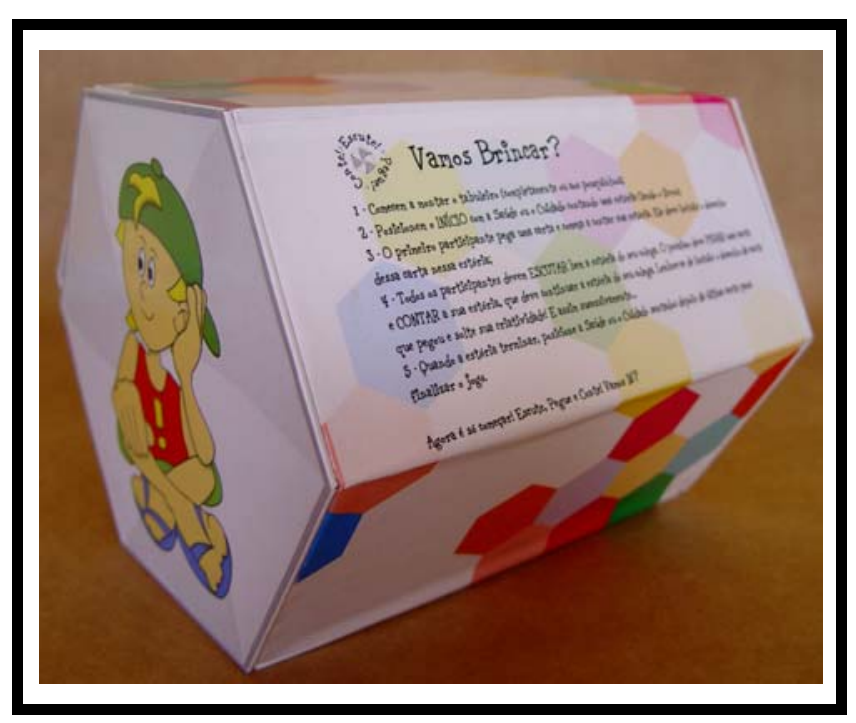

Figura 4.71- Caixa do jogo real 3

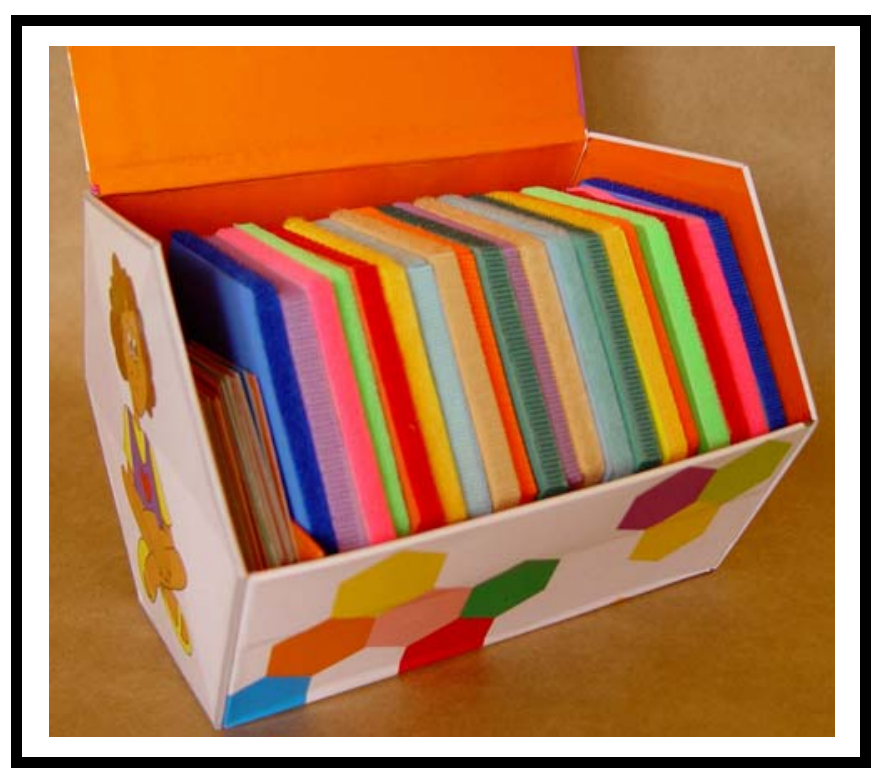

\subsubsection{Como o jogo funciona?}

O jogo é uma brincadeira de contar estórias. A estratégia do jogo baseia-se em três ações recorrentes. A ação de escutar o colega (escute!), de pegar uma carta (pegue!) e de contar uma estória (conte!). Por isso o jogo chama-se Escute! Pegue! Conte! 
Figura 4.72- Caixa do jogo

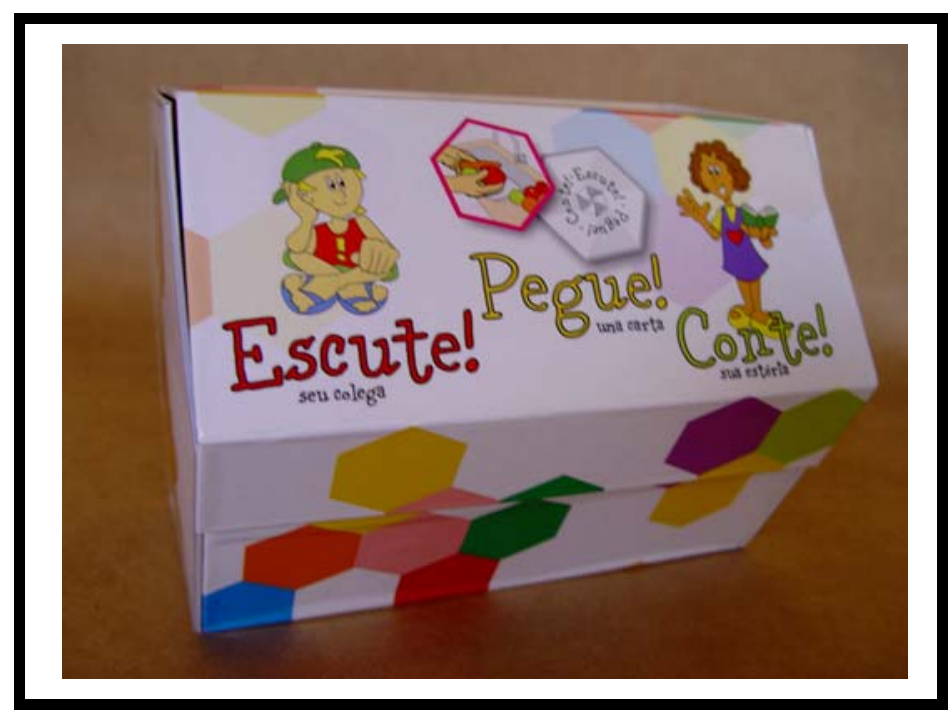

Figura 4.73- Caixa do jogo e jogo

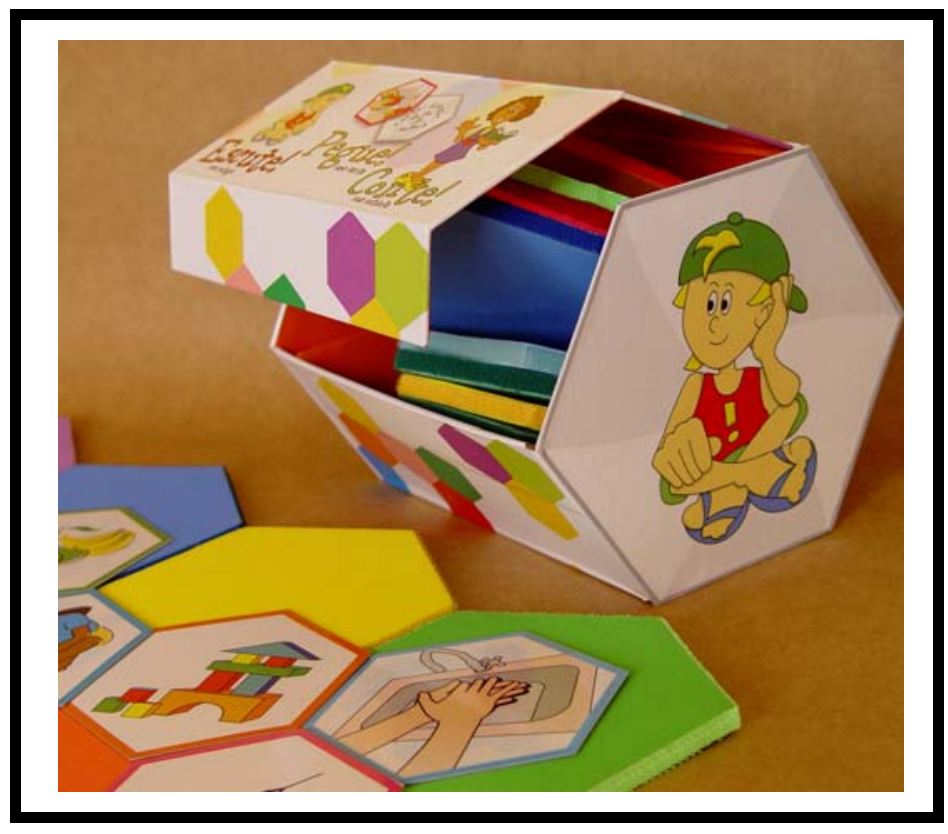

Há duas cartas responsáveis pelo início e fim do jogo, como “cartas símbolos”. Nelas há escrito “início” e “fim” com as opções da "Saúde” ou o "Cuidado” começando ou terminando a estória. Essa opção existe para os participantes escolherem quem estará no tabuleiro contando ou ouvindo a estória, se a Saúde ou o Cuidado. 
Figura 4.74- Cartas do jogo

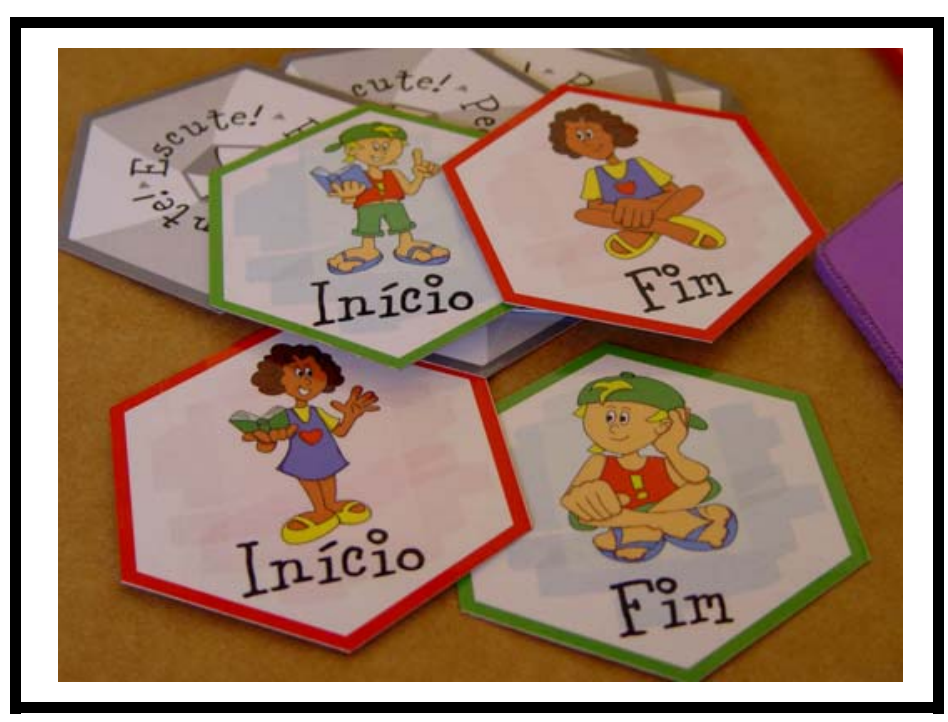

Figura 4.75- Cartas e tabuleiro

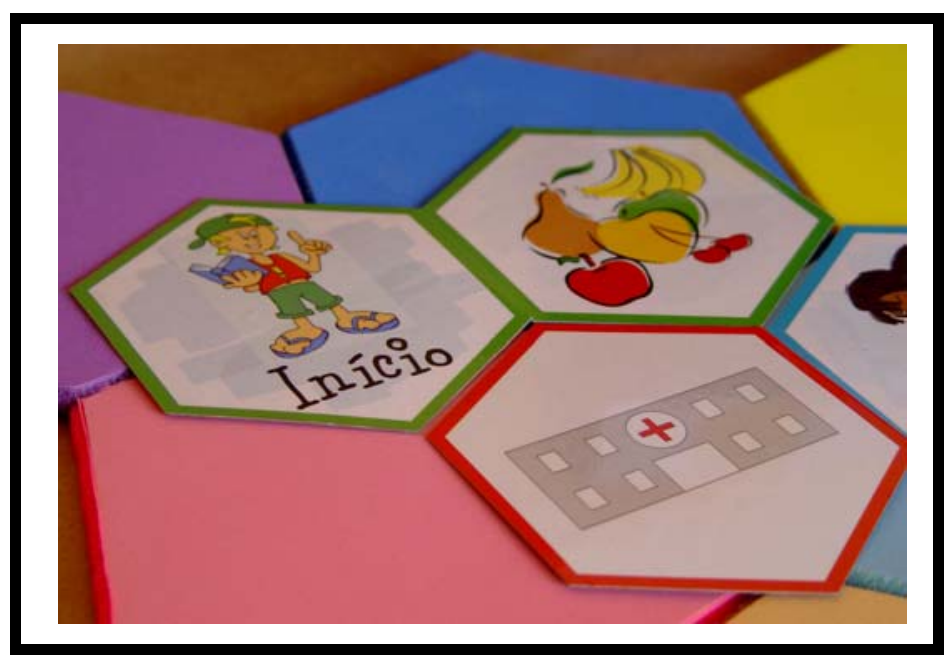

Os participantes devem ouvir a estória dos colegas, pegar uma carta e continuar a estória que estava sendo contada, inserindo nela a imagem da carta que pegou. O primeiro participante, é claro, começa a estória e esta deve conter algo da imagem da carta que pegou. Após o início, as três ações - Escute! Pegue! Conte! - passam a acontecer nessa ordem, sucessivamente, até os participantes opinarem por parar de inventar estórias ou as cartas acabarem e, assim, colocarem a carta “fim” no tabuleiro. 
Figura 4.76- Carta “fim” no tabuleiro

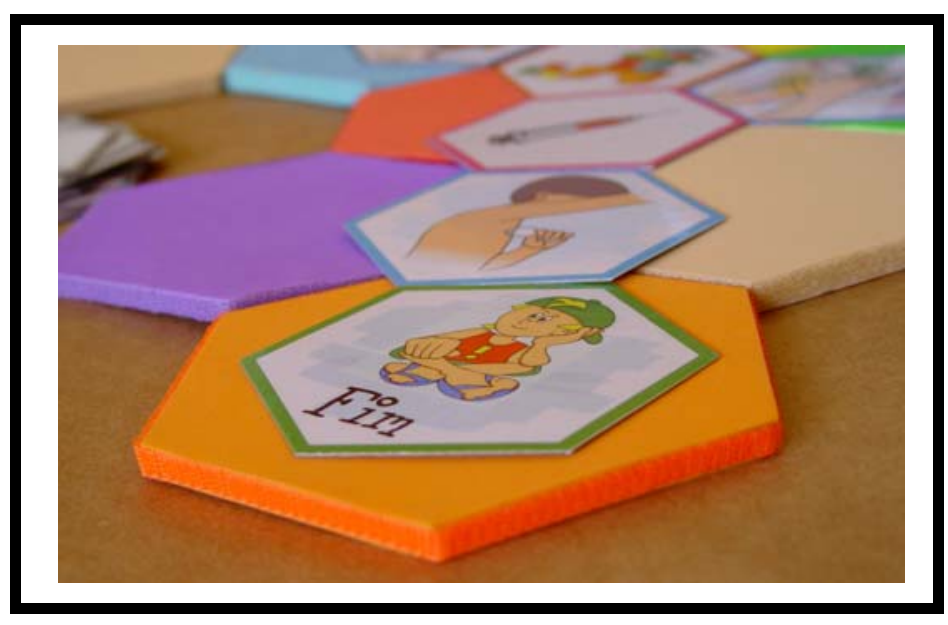

O jogo possui 20 peças que formam o tabuleiro. Esse tabuleiro pode ser montado por completo no início, com os participantes escolhendo a forma que ele terá, ou aos poucos enquanto a estória vai sendo contada. Os tabuleiros têm forma hexagonal e velcro em suas laterais. A forma hexagonal, entre as formas geométricas, é a que mais oferece possibilidades de arranjo. O velcro existe para reforçar a montagem do tabuleiro e unir as peças para que não se movam no decorrer do jogo, atrapalhando a dinâmica do mesmo.

Figura 4.77- Jogo

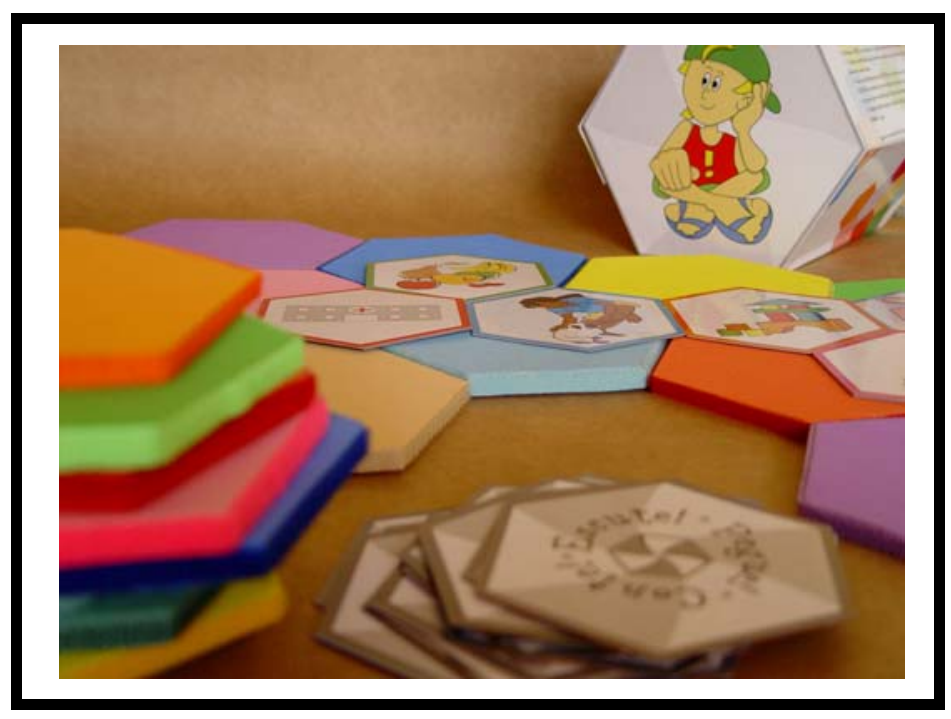


Figura 4.78- Peças do tabuleiro e cartas na caixa

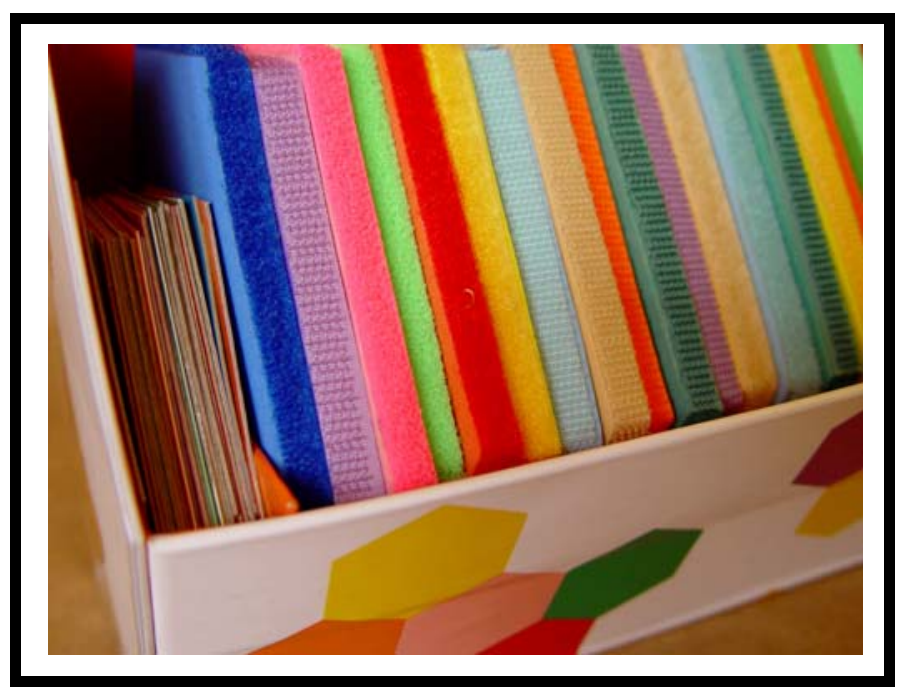

\subsubsection{Aspectos do desenvolvimento infantil que são estimulados pelo jogo}

Como o jogo Escute! Pegue! Conte! é um jogo cooperativo, pode-se trabalhar vários aspectos do desenvolvimento infantil como o desenvolvimento físico: intelectual, artístico criativo, dos sentidos, afetivo, social e ético. Como por exemplo:

- a coordenação;

- a consciência;

- controle;

- a precisão;

- $\quad$ a rapidez, de criar a estória e contá-la

- $\quad$ a experiência sensorial tátil e visual;

- registro temporal, cronologia;

- a descoberta, a surpresa;

- a comparação, associações;

- a linguagem na hora de contar as estórias;

- a personalidade;

- caráter;

- a expressão das idéias; 
- o sentimento de cooperação;

- o respeito pela vez do outro;

- a criatividade ao ter que criar a sua própria estória e inserir o novo elemento da carta;

- a atenção ao prestar atenção na estória do seu colega para poder construir a sua;

- o convívio social ao interagir com outros pais e crianças;

- a memória visual e verbal por ter que lembrar dos elementos contados anteriormente para poder continuar a estória;

- a dedução ao continuar a estória inserindo a imagem da carta;

- o afeto entre pais e crianças já que eles podem participar juntos ou separados do mesmo jogo;

- a fabulação, o sonho;

- o espírito de equipe;

- $\quad$ o respeito pela estória dos colegas;

- a paciência para escutar e entender a estória dos colegas.

Além desses aspectos o jogo pode abordar outras áreas mais específicas que queiram ser trabalhadas pelos condutores do jogo já que o objetivo principal do jogo é possibilitar a conversa entre crianças e psicólogos sobre assuntos que interessem esses profissionais, a fim de ajudá-los no atendimento e tratamento das crianças.

\subsubsection{Detalhamentos técnicos dos componentes do jogo}

\subsection{Tabuleiro}

Descrição: 20 peças hexagonais em borracha E.V.A. com as laterais cobertas com velcro, sendo 3 lados do hexágono o velcro “fêmea” e 3 lados do hexágono o velcro “macho”; Material: borracha E.V.A. colorida e velcro colorido; 
Dimensões: 13,5 x 15,5 centímetros, hexágono de lado 8 centímetros e espessura de 8 milímetros.

\subsection{Cartas}

Descrição: 24 cartas hexagonais em papel plastificado (frente e verso);

Material: papel cartão, papel contact e papel adesivo;

Impressão: laser (4 cores) em papel adesivo (4 cartas em tamanho A3);

Dimensões: 10 x 11,5 centímetros, hexágono de lado 6 centímetros.

\subsection{Caixa}

Descrição: sólido hexagonal em papel plastificado com tampa com sistema magnético;

Material: papel paraná, papel adesivo, papel color plus laranja, papel contact e folha magnética adesiva;

Impressão: laser (4 cores) em papel adesivo;

Dimensões: 16 x 20,6 x 18,7 centímetros

IMPORTANTE: Há uma preocupação para que todos os componentes do jogo, quando possível, sejam de fácil limpeza, por estarem em um hospital. Além disso, há também uma preocupação quanto à vida útil do jogo. Os materiais usados são os melhores possíveis, tratando-se de um jogo artesanal, para que haja durabilidade e suporte manuseios constantes.

\subsubsection{Banner de apresentação da campanha}

O banner tem a função de apresentar a campanha “Amigos para sempre: A Saúde, o Cuidado e você!”. O banner é o primeiro contato que as crianças, médicos, pais e transeuntes do hospital têm com a campanha e conseqüentemente, com os personagens Saúde e Cuidado. 
É no banner que a poesia da campanha está presente, a poesia que é a responsável pela apresentação lúdica da campanha, a mesma que faz a brincadeira e a relação entre os conceitos de saúde e cuidado e os personagens a Saúde e o Cuidado.

O banner é mais um produto do projeto e, portanto, este deve manter a identidade visual do projeto como um todo e as características formais dos personagens.

As alternativas que foram desenvolvidas têm o objetivo de dispor a poesia de forma atrativa e que privilegie a leitura.

Figura 4.79 - Geração banner 1

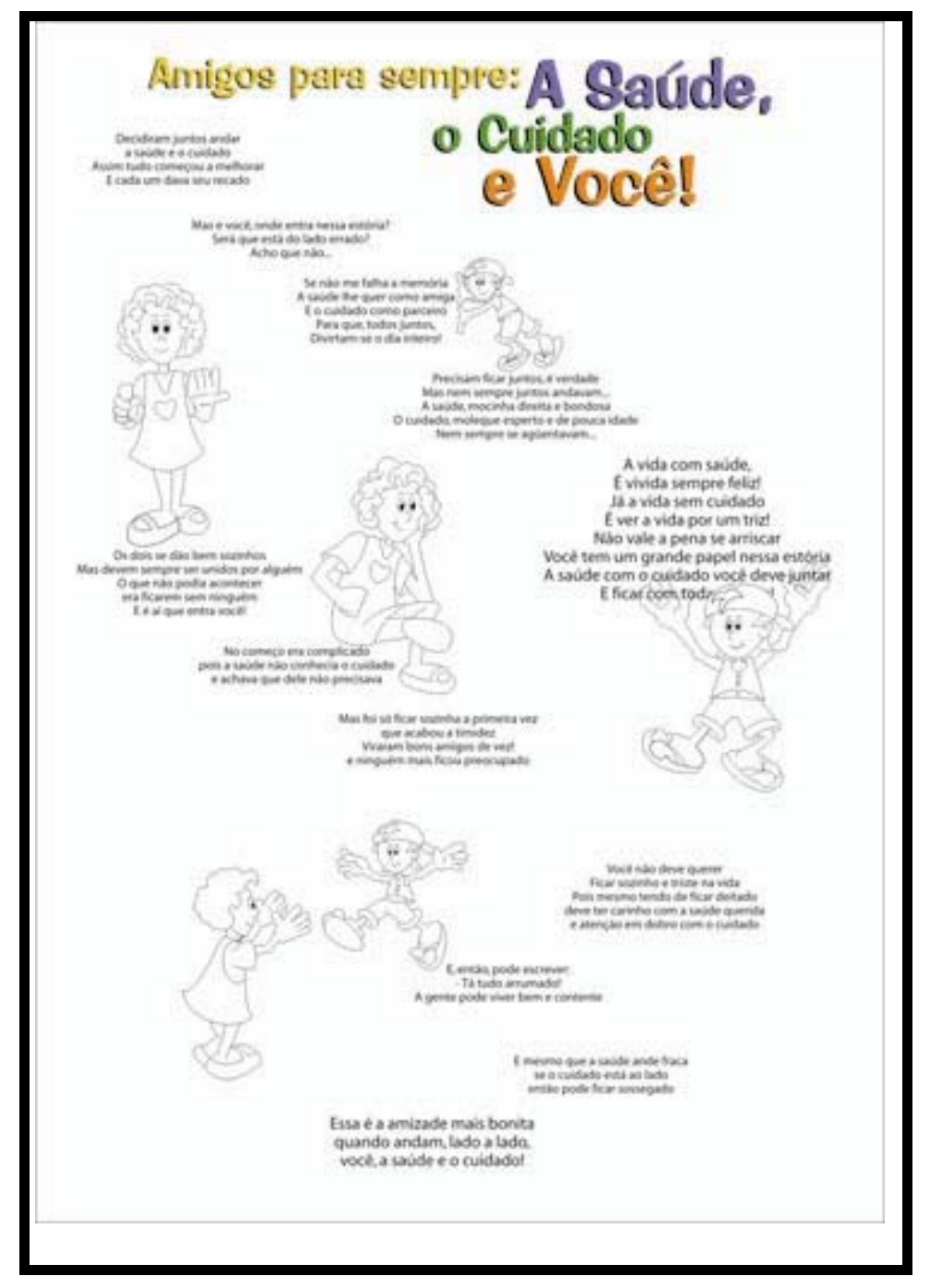

A primeira alternativa usa a mesma fonte e cores utilizadas nos painéis explicativos no título da campanha. Distribui a poesia desordenadamente interagindo com os personagens. A idéia - de interação dos personagens com os trechos da poesia - nasceu da importância de 
relacionar os conceitos de saúde e cuidado com os personagens. Como o banner é quem apresenta a campanha e conseqüentemente os personagens, é importante que esteja claro quem são a Saúde e o Cuidado e quais as suas características. Dessa forma a poesia e os próprios personagens se apresentam, como se tivessem conversando com “você!”. A poesia conta uma estória, uma situação, uma característica do personagem e a Saúde ou o Cuidado estão ilustrando a informação.

Figura 4.80 - Geração banner 2

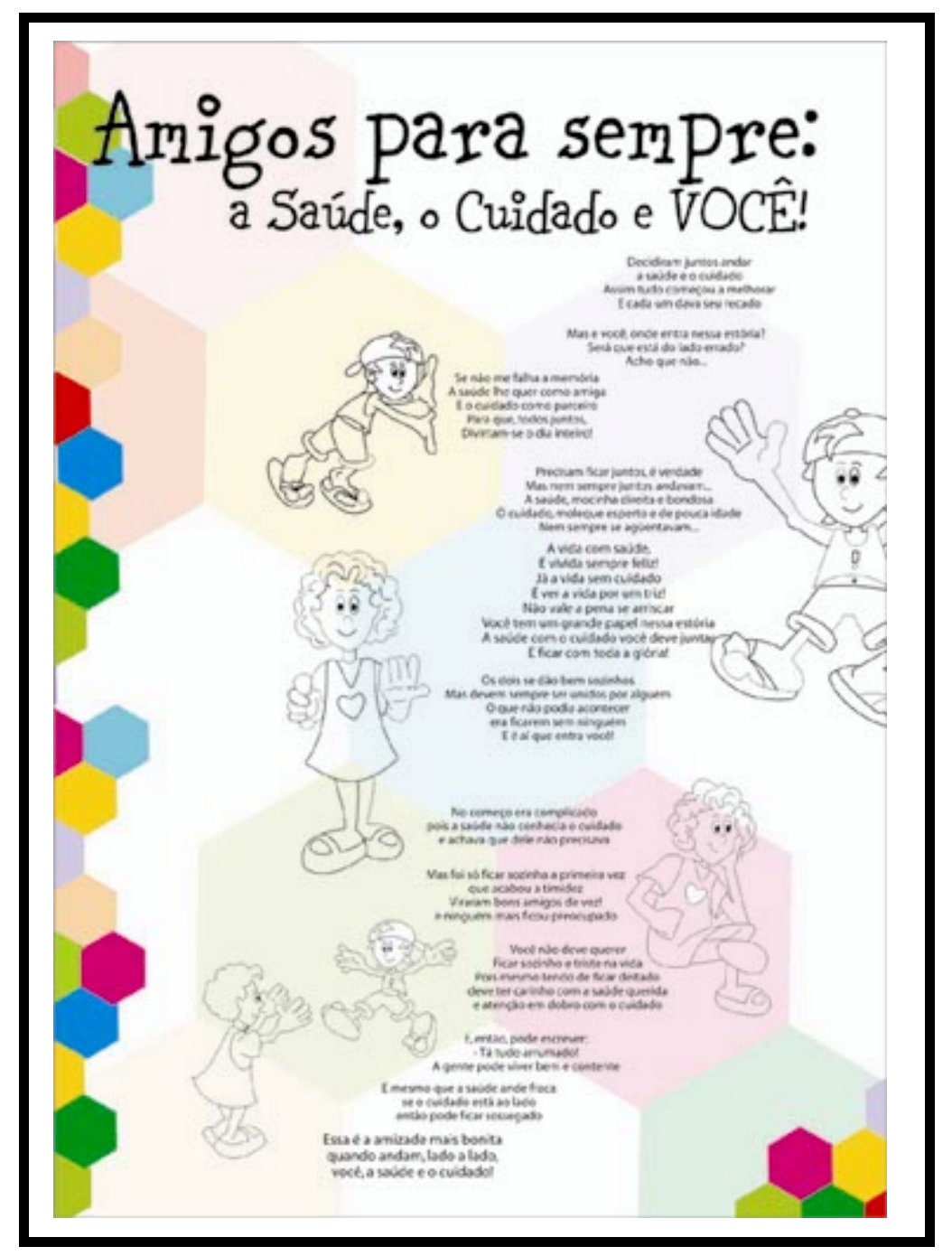

A segunda alternativa organiza melhor a poesia, a ordem das estrofes fica mais clara e os personagens são também melhor distribuídos. Utilizam-se elementos do jogo desenvolvidos no projeto, os hexágonos, para melhor compor e colorir o banner e, também, fazer sua associação ao jogo Escute! Pegue! Conte!. A tipografia usada no título também é a 
mesma do jogo, Carnation, e a tipografia do texto é a mesma das frases dos balões dos painéis, Myriad Roman.

Figura 4.81 - Banner final

\section{Amigos para sempre: a Saúde, o Cuidado e Você!}

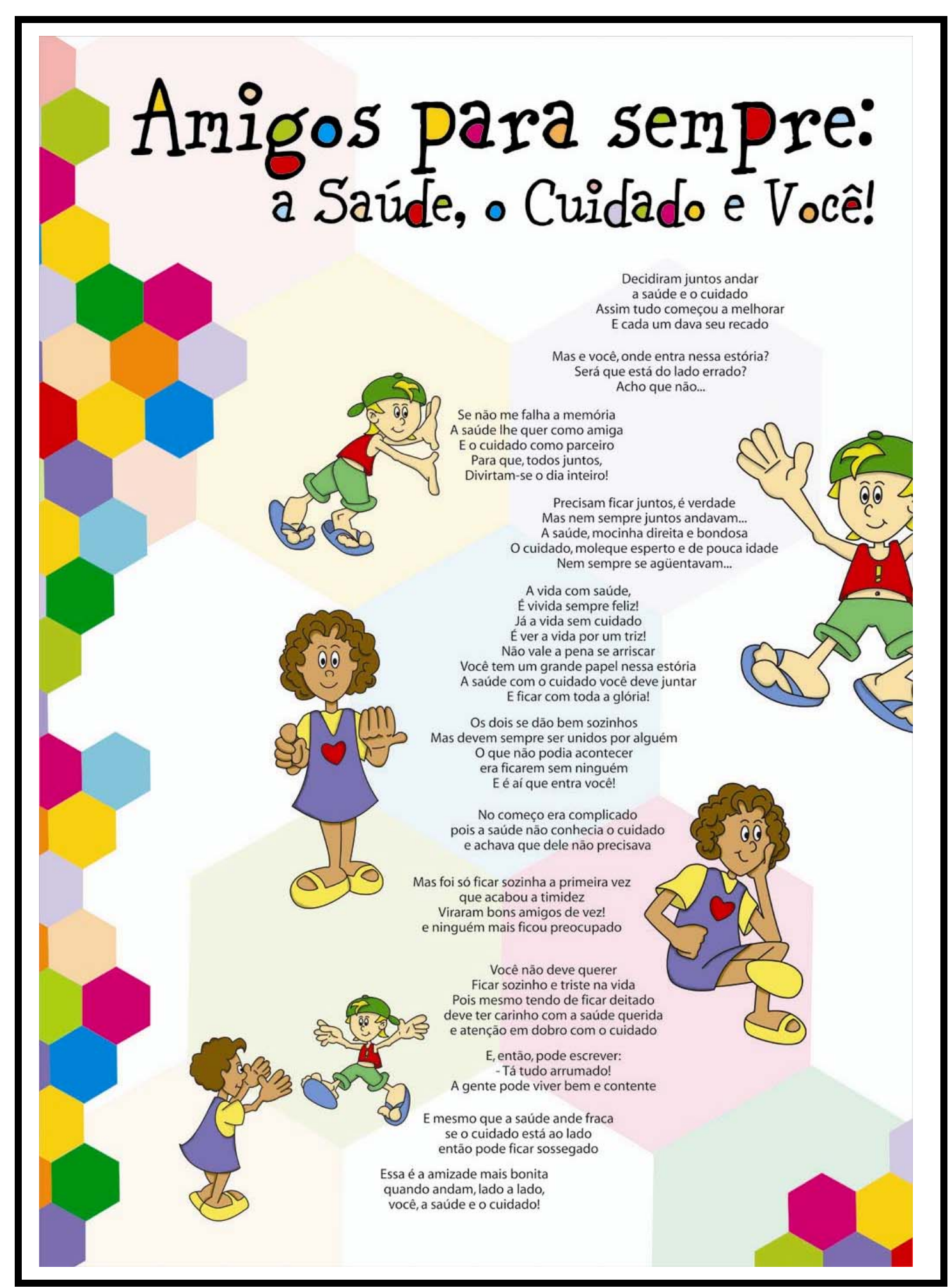


Os elementos como hexágonos, cores, tipografia e personagens fazem alusão aos elementos utlizados no jogo e nos painéis, ou seja, na campanha. A tipografia usada também é a mesma do jogo, Carnation, com preenchimento colorido nas letras que contêm formas fechadas, e a tipografia do texto é a mesma das frases dos balões dos painéis, Myriad Roman.

\subsubsection{Detalhamentos técnicos do banner}

- Tamanho: $100 \times 70$ centímetros

- Impressão: plotagem colorida (4 cores)

- Material: lona externa (que possa ser limpada)

- Acabamento: cano pvc e corda para pendurar

\subsection{Teste do jogo Escute! Pegue! Conte!}

- Primeiro teste realizado com o jogo Escute! Pegue! Conte!

- Data: 16/06/04 de 14h30 às 15h30

- Local: Sala de recreação do HAB

- Condutora: Dra. Sílvia Coutinho

- Supervisão: Dr. Áderson Costa

- Participantes: oito crianças de três a oito anos e duas mães.

A proposta dessa avaliação do jogo é perceber a aceitação e envolvimento dos participantes com a brincadeira de contar estórias e com os componentes do jogo. Assim, a condutora, Dra. Sílvia Coutinho, apresentou o jogo de forma livre, apenas com a "regra” de contar uma estória inserindo a imagem da carta escolhida. Dessa forma, os participantes puderam interagir com o jogo de maneiras diferentes, inclusive, diferentes da maneira esperada.

A brincadeira durou uma hora e foi conduzida pela Psicóloga responsável do Hospital de Apoio. Foi realizada na sala de recreação, onde as crianças e pais esperam por consultas e 
exames. Ela convidou as crianças que estavam na sala para brincar com um novo jogo, um jogo de contar estórias. Porém, inicialmente, somente as crianças mais novas se interessaram pela brincadeira. As mais velhas pareciam sentir vergonha, mas, depois que o jogo começou, elas passaram a se aproximar e a querer participar.

Como havia vários pais e crianças na sala de recreação nessa tarde, o barulho e distrações foram intensos dificultando a atenção inicial dos participantes no jogo. Com o passar do tempo, as crianças prenderam sua atenção ao jogo, participando ativamente da construção da estória. Outro fator interessante que pôde ser observado foram os olhares curiosos, os sorrisos, a atenção e o interesse dos pais e das pessoas em volta na brincadeira.

\subsubsection{Resultados do teste do jogo}

\subsubsection{Pontos positivos}

- Grande interesse e motivação das crianças e pais que participaram, mesmo sendo o primeiro contato com o jogo;

- Após a primeira rodada do jogo, as crianças prontamente quiseram começar outra rodada, outra estória, mostrando seu interesse pelo novo jogo;

- Pôde-se perceber que o visual do jogo (caixa, cartas, peças do tabuleiro, ilustrações e personagens), além de chamar a atenção, atraiu os participantes durante a brincadeira, prendendo o olhar nos componentes do jogo;

- As cartas com as ilustrações eram esperadas com ansiedade e curiosidade e, quando reveladas, a nova cena da estória era contada com empolgação (as crianças se interessavam em saber qual seria a próxima figura para pensar como encaixá-la na estória);

- Pela não delimitação de regras rígidas, o jogo pode ser conduzido de diferentes maneiras, dependendo do objetivo do condutor. O jogo pode ser usado, por exemplo, 
para avaliar interação social das crianças, para transmitir informação interativa e educativa, para avaliar o repertório verbal, para mera recreação, para avaliar a noção de seqüência ou o conhecimento de cores;

- É um jogo que possibilita a participação dos pais e crianças independentemente da idade, porém é interessante que, entre as crianças, haja uma mesma faixa etária, para que se possa manter o mesmo ritmo entre os participantes;

- Pôde-se perceber uma aceitação das crianças pelos personagens e seus nomes. As crianças observaram com atenção e memorizaram seus nomes.

\subsubsection{Pontos a serem reavaliados}

- A necessidade de utilização do velcro nas laterais das peças do tabuleiro, pois nesse teste o velcro não foi utilizado;

- A necessidade do uso das peças do tabuleiro, pois observou-se que é possível jogar sem ele. Porém essas peças, por serem coloridas e de grande formato, foram responsáveis por grande parte da atratividade do jogo;

- A utilização da ilustração do sorvete “banana split”, pois esta não foi reconhecida. As crianças pensaram que era um bolo;

- A utilização da ilustração de lavar os alimentos, pois ela foi interpretada como “comer tomate com cebola”;

- As crianças não sabiam o nome do estetoscópio, mas sabiam que era um aparelho do médico para ouvir o coração;

- A inserção dos personagens Saúde e Cuidado em algumas cartas para que os participantes se familiarizem e os tornem presentes nas suas falas e cotidiano;

- A quantidade de cartas, pois as vinte e quatro testadas logo acabaram e as crianças queriam continuar a estória. 
- Diversidade nas ilustrações das cartas, pois situações parecidas foram demasiadamente repetidas nas três estórias que foram elaboradas;

- Formato e espaço da caixa de armazenamento do jogo para comportar o novo número de cartas que serão posteriormente desenvolvidas.

\subsubsection{Outras observações}

- Possibilidade de incluir temas diferentes nas ilustrações das cartas para diversificar as estórias e possibilitar diferentes aplicações e objetivos com o jogo. Por exemplo, brincar com crianças que tenham medo de dentista apenas com cartas que ilustrem esse assunto, possibilitando transmitir informações educativas e mais específicas ao assunto;

- As cartas temáticas devem permanecer visualmente distintas através das cores para facilitar a escolha do tema (ou temas) pelos profissionais na hora da brincadeira;

- condutor da brincadeira deve ter conhecimento da proposta do jogo e boa habilidade com crianças para saber conduzir o jogo de maneira a alcançar o objetivo da recreação;

- Esperava-se que a realidade e as experiências de vida das crianças fossem projetada nas estórias contadas, porém houve uma preferência em criar “estórias malucas” por conta das diferentes imagens que apareciam nas cartas. As crianças ficaram entusiasmadas com as imagens e criavam as estórias com prioridade na fantasia e faz-de-conta e menos na projeção da realidade.

Essas observações foram avaliadas levando em consideração especificamente esse grupo de crianças, essa condutora, essa proposta, nesse ambiente, nessa tarde, no HAB, ou seja, essas observações não podem ser generalizadas e nem conclusivas em relação às possibilidades do jogo Escute! Pegue! Conte! Portanto, concluí-se que se faz necessária a realização de novas avaliações com o jogo em diferentes ambientes com diversas faixas 
etárias e diferentes objetivos, ou seja, avaliar o jogo nas várias situações nas quais pode estar sendo submetido no ambiente hospitalar. Essas avaliações posteriores têm o objetivo de testar as diversas possibilidades de utilização do jogo, além de pontos positivos e possíveis falhas. Dessa forma, a partir das conclusões encontradas posteriormente, poder-se-á formular e aperfeiçoar o jogo para melhor adaptação e atendimento da realidade e dos objetivos dos profissionais de saúde do HAB.

Figura 4.82 - Teste do jogo 1

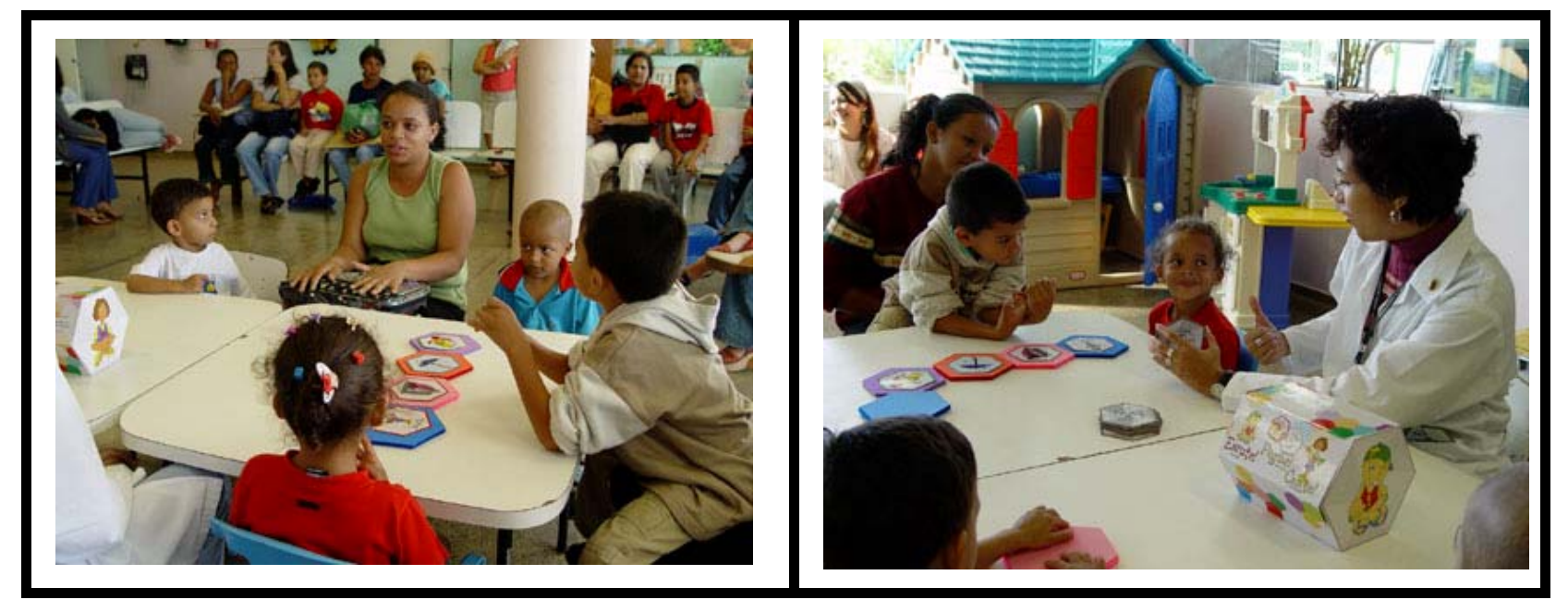

Figura 4.83 - Teste do jogo 2

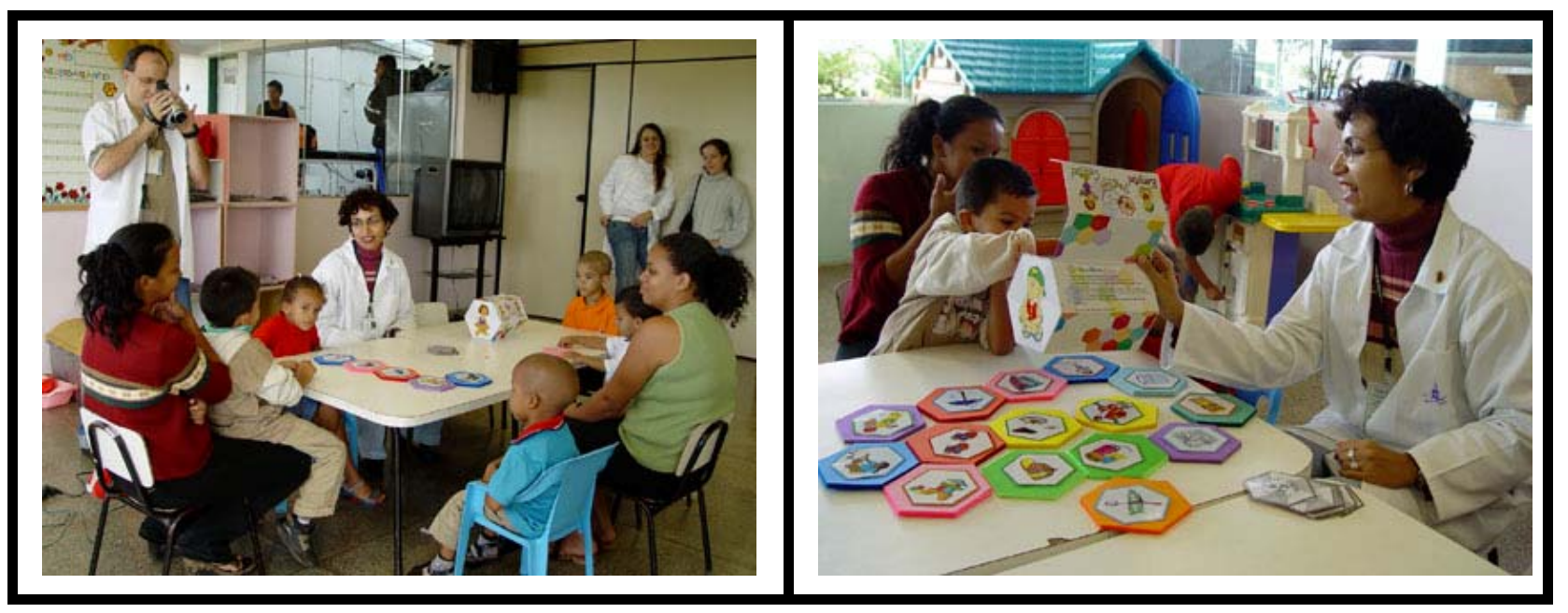


Figura 4.84 - Teste do jogo 3

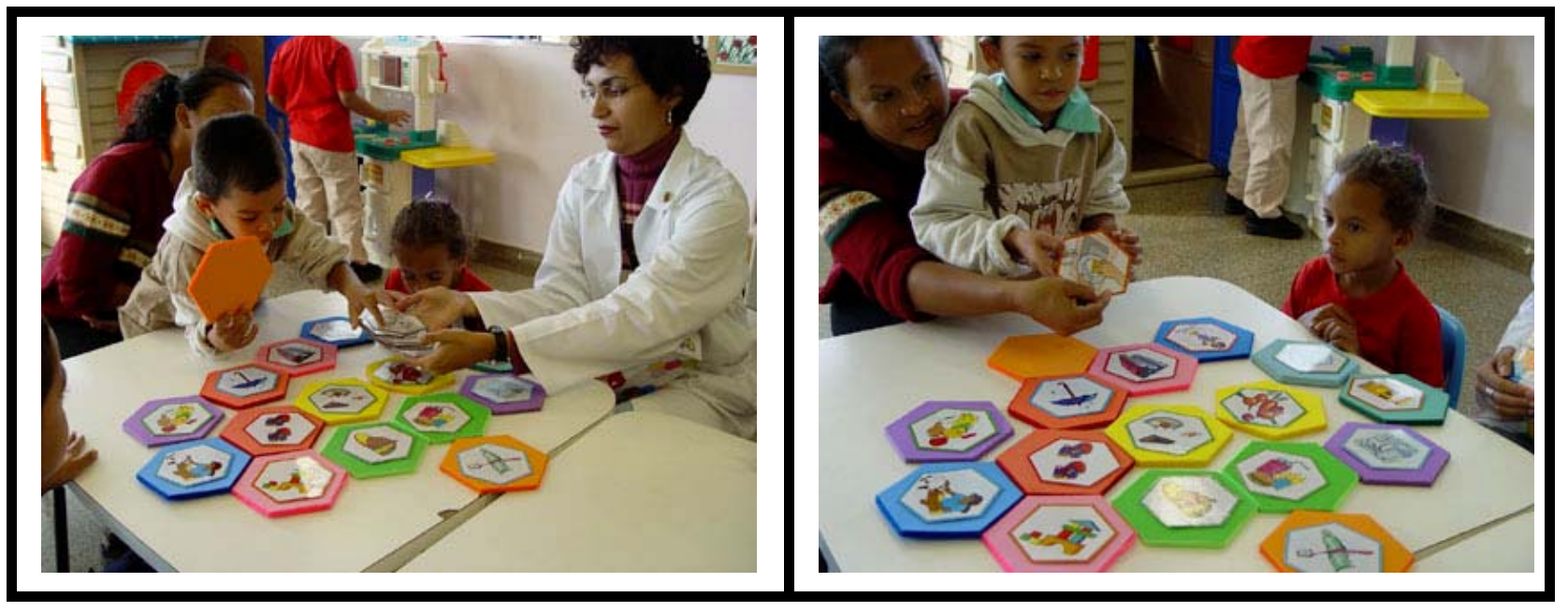

Figura 4.85 - Teste do jogo 4

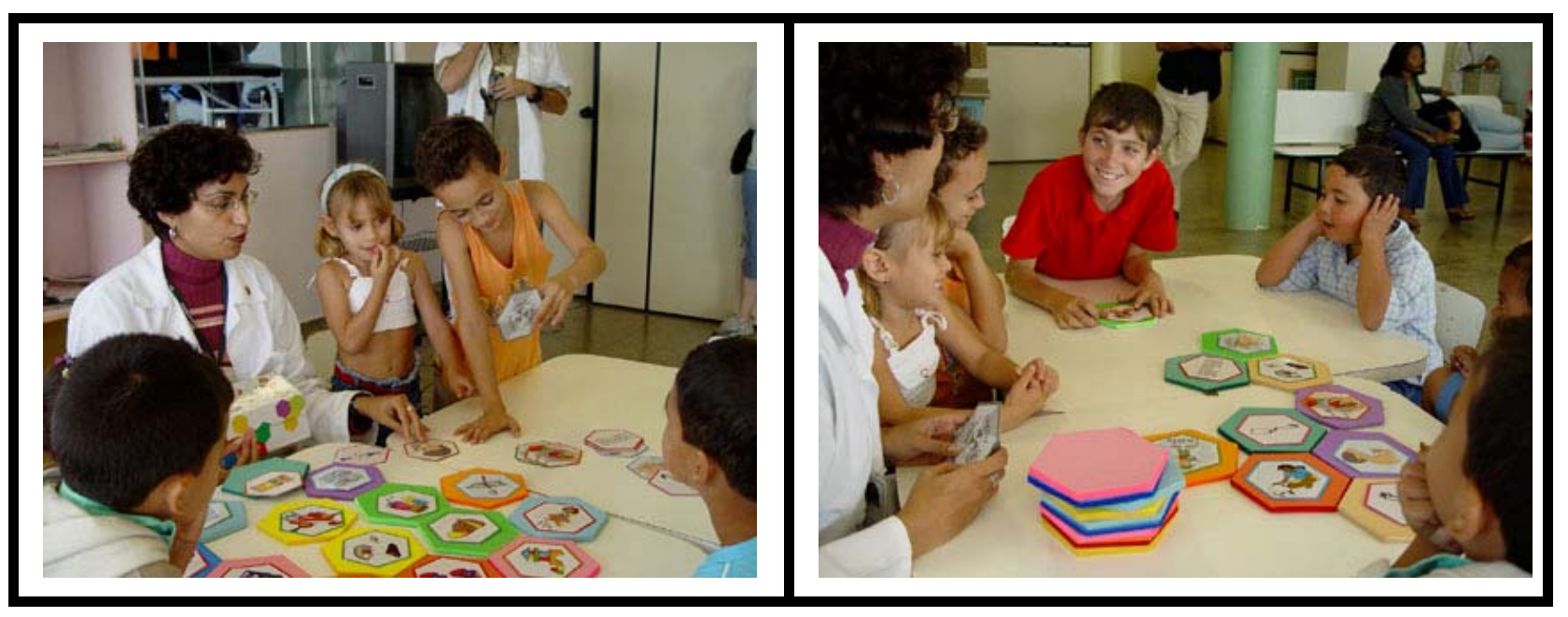




\section{CONCLUSÃO}

Há muitos pontos a serem abordados no decorrer desta conclusão, porém, antes de se tratar de aspectos específicos, há três questões mais gerais percebidas com este projeto, que se mereceu destaque especial pela sua importância em relação à profissão do designer gráfico.

O primeiro aspecto que se deseja ressaltar é a diversidade de trabalhos que um designer gráfico pode desenvolver dentro de um mesmo assunto, saúde, e com um mesmo públicoalvo, crianças e seus pais (ou acompanhantes). Como a todo o momento perseguiu-se a atitude de perceber a necessidade existente no ambiente, no caso, o Hospital de Apoio de Brasília, observou-se que, para um mesmo propósito, o de facilitar a comunicação entre psicólogos, crianças e pais e promover uma melhor assimilação das informações, diferentes produtos podem ser desenvolvidos.

Para atender a um bom projeto de diplomação, optou-se por desenvolver 3 produtos: os painéis explicativos, o jogo e o banner. Mas existem outros diversos produtos que poderiam ser desenvolvidos como, por exemplo, um álbum digital das crianças em tratamento e crianças curadas, um material gráfico específico para explanações, como um dente em formato grande para explanações de odontologia; ou um corpo humano com as veias também em grande formato para explanações sobre doença falciforme, entre outros.

O segundo aspecto é a importância do lado social do projeto. Há uma relevância social e o projeto desenvolvido agrega utilidade e valor. Estar voltado para a sociedade, para colaborar positivamente para o seu crescimento e desenvolvimento, mesmo que seja de uma pequena comunidade dentro dessa sociedade, é um fator que enriquece o significado deste projeto, já que estamos ajudando outras pessoas, colaborando com a transformação social. O projeto tem 
os objetivos gerais e específicos previstos na introdução deste projeto, mas também tem um objetivo social, ou melhor, uma função social agregada.

O terceiro aspecto é o fato de haver a necessidade de realizar testes posteriores dos produtos no ambiente específico e com as pessoas que os utilizarão. Apesar das pesquisas das abordagens teóricas, entrevistas e observações realizadas no desenvolver do projeto, observam-se aspectos diferentes com os novos produtos. Como este projeto é real e pretende atender de fato às necessidades do Hospital de Apoio, o teste faz-se muito necessário para perceber a funcionalidade dos produtos desenvolvidos. Observa-se que o embasamento do projeto é de extrema importância para definir conceitos e especificar com clareza os objetivos propostos. Porém, o embasamento não exclui problemas reais quando usado ou melhoras no produto. O teste, o voltar-se ao “cliente”, é essencial para um desenvolvimento de produto completo, mais aprimorado.

O conceito, as propostas e a identidade visual dos produtos desse projeto estão definidos e embasados. Toda essa definição deveu-se essencialmente à elaboração inicial da campanha de conscientização sobre saúde, que uniu todos os elementos e todos os seus componentes, a partir da utilização de uma mesma linguagem, formas e conceitos. Com a campanha foi possível organizar o projeto e perceber uma identidade de informação, a identidade da informação visual.

Há uma identidade visual forte entre os elementos da campanha e são os personagens os elementos fundamentais das soluções formais dos produtos. Haverá continuidade desse projeto, para finalização de todas as ilustrações e painéis necessários ao Hospital, assim como seus testes e refinamento do projeto. O jogo, ainda não concluído, passará por testes com sujeitos e ambientes diversos para compreender seus efeitos e perceber qual a melhor solução formal para seu objetivo. A identificação, das crianças e pais com os personagens, também será avaliada a fim de perceber se esses alcançam o objetivo definido. 
Apesar dos produtos terem atingido os objetivos gerais propostos no início do projeto, como por exemplo, desenvolver o projeto gráfico para o material de apoio às explanações e desenvolver um jogo para crianças, ainda se faz necessário a realização de testes científicos para ratificar os objetivos específicos. Além disso, percebe-se também que, com o que já foi desenvolvido e com o retorno dos profissionais de saúde envolvidos, os produtos - painéis, banner e jogo - apresentam respostas positivas às necessidades atuais. 


\section{BIBLIOGRAFIA}

ABRACE, Associação Brasileira de Assitência às Famílias de Crianças Portadoras de Hemopatias. Apresenta o projeto social de ajuda às crianças com câncer. Disponível em <http://www.abrace.com.br>. Acesso em: 2 abr. 2004.

BEE, Helen L. A pessoa em desenvolvimento. 2ed. São Paulo: Editora Harbra ltda, 1986

A criança em Desenvolvimento. São Paulo: Harper \& Row do Brasil, 1977

CHATEAU, Jean. O jogo e a Criança. São Paulo: Summus, 1987 (Novas Buscas em Educação, v.29)

COOPERANDO, Cooperando em Redes. Instituto para cooperação. Apresenta informações sobre jogos cooperativos. Disponível em <http:// www.cooperando.org.br/jogos.htm>

DEPARTAMENT OF TYPOGRAPHY \& GRAPHIC DESIGN AT THE UNIVERSITY OF READING. Apresenta pesquisa sobre tipografia para crianças. Disponível em <http://www.textmatters.com/kidstype/index.html>. Acesso em: 28 abr. 2004.

DOHME, Vania. O Valor Educacional dos Jogos. São Paulo: Informal Editora, 2003 (Série Jogando: foca lúdica)

FARINA, Modesto. Psicodinâmica das Cores em Comunicação. 4ed. São Paulo: Editora Edgard Blüncher ltda, 2000.

INSTITUTO AYRTON SENNA. Apresenta informações sobre os projetos sociais que o instituto organiza. Disponível em <http:// http://senna.globo.com/senninha/>. Acesso em: 13 mai. 2004.

INSTITUTO RONALD MCDONALD. Apresenta informações sobre o projeto social de ajuda às crianças com câncer. Disponível em <http://www.instituto-ronald.org.br>. Acesso em: 13 mai. 2004.

KISHIMOTO, Tizuko Morchida (Org.). Jogo, Brinquedo, Brincadeira e a Educação. 2 ed. São Paulo: Cortez, 1997 
KISHIMOTO, Tizuko Morchida. O jogo e a Educação Infantil. São Paulo: Pioneira, 2002 (Série A Pré-Escola Brasileira)

LOWENFELD, V. e BRITTAIN, W.L. Desenvolvimento da Capacidade Criadora. V. Lowenfeld e W.L. Brittain; tradução de Selma Cury. São Paulo: Mestre Jou, 1970.

MCCLOUD, Scott. Desvendando os quadrinhos. Scott McCloud; tradução Hélcio de Carvalho, Marisa do Nascimento Paro. São Paulo: Markron Books, 1995.

MC DONALDS, Brasil. Apresenta assuntos sobre a criação do personagem “Zé gotinha”. Disponível em $<$ http://www.mcdonalds.com.br/sala_imprensa/not00226020822poliomelite.shtml>. Acesso em: 6 mai. 2004.

MINISTÉRIO DA SAÚDE. Apresenta informações sobre a proposta e objetivos do HumanizaSUS - Política Nacional de Humanização. Disponível em <http://portal.saude.gov.br/saude/area.cfm?id_area=389>. Acesso em: 30 jun. 2004

MINISTÉRIO DA SAÚDE. HumanizaSUS-Política Nacional de Humanização: Documento para Discussão, Brasília: 2003, p. 14-17. Disponível em http://lildbi.saude.gov.br/cgi-in/wxis.exe/iah_txtc/?IsisScript=iah/iah.xic\&lang=P\&base=txtc, procurar pela palavra chave: humanização>. Acesso em: 30 jun. 2004

MONTIGNEAUX, Nicolas. Público - alvo: crianças - a força dos personagens para falar com o consumidor infantil. Nicolas Montigneaux; tradução de Jaime Bernardes. - Rio de Janeiro: Campus, 2003.

MORAES, Anamaria de \& MONT’ALVÃO, Cláudia. Ergonomia: conceitos e aplicações. 2 ed. Rio de Janeiro: 2AB, 2000

NOVELLO, Fernanda Parolari. Psicologia Infantil. 2 ed. São Paulo: Ed. Paulinas, 1987

PEARCE, Joseph Chilton. A Criança mágica: a redescoberta do plano da natureza para nossas crianças. Joseph Chilton; tradução de Cinthia Barki. Rio de Janeiro: F. Alves, 1989.

PICKARD, Phyllis Marquerite. A criança aprende brincando; tradução de Noé Gertel. São Paulo, IBRASA, 1975.

REDE INFANTO-JUVENIL DE INFORMAÇÕES SOBRE O CÂNCER. Apresenta informações sobre o câncer para a criança. Disponível em <http://www.redeinfantojuvenil.com.br>. Acesso em: 24 mar. 2004. 
RIBEIRO, Milton. Planejamento Visual Gráfico. Milton Ribeiro 7ed. ver. e atualizada. Brasília: Linha Gráfica Editora, 1998.

ROCHA, Luiz Carlos de Assis. Como elaborar trabalhos acadêmicos. Luiz Carlos de Assis Rocha. 3ed. Ver. Belo Horizonte: Ed. Do autor, 2002. 